University of Louisville

ThinkIR: The University of Louisville's Institutional Repository

Electronic Theses and Dissertations

8-1981

\title{
The Louisville (Kentucky) Democratic Party : political times of "Miss Lennie" McLaughlin.
}

Carolyn Luckett Denning 1943-

University of Louisville

Follow this and additional works at: https://ir.library.louisville.edu/etd

\section{Recommended Citation}

Denning, Carolyn Luckett 1943-, "The Louisville (Kentucky) Democratic Party : political times of "Miss Lennie" McLaughlin." (1981). Electronic Theses and Dissertations. Paper 333.

https://doi.org/10.18297/etd/333

This Master's Thesis is brought to you for free and open access by ThinkIR: The University of Louisville's Institutional Repository. It has been accepted for inclusion in Electronic Theses and Dissertations by an authorized administrator of ThinkIR: The University of Louisville's Institutional Repository. This title appears here courtesy of the author, who has retained all other copyrights. For more information, please contact thinkir@louisville.edu. 
THE LOUISVILLE (KENTUCKY) DEMOCRATIC PARTY:
POLITICAL TIMES OF "MISS LENNIE" MCLAUGHLIN

\author{
By \\ Carolyn Luckett Denning \\ B.A., Webster Collège, 1966

\begin{abstract}
A Thesis
Submitted to the Faculty of the

Graduate School of the University of Louisville

in Partial Fulfillment of the Requirements

for the Degree of
\end{abstract} \\ MASTER OF ARTS \\ Department of Political Science \\ University of Louisville \\ Louisville, Kentucky
}

August 1981 
(C) 1981

CAROLYN LUCKETT DENNING

All Rights Reserved 
THE LOUISVILLE (KENTUCKY) DEMOCRATIC PARTY:

POLITICAL TIMES OF "MISS LENNIE" MCLAUGHLIN

By

Carolyn Luckett Denning

B.A., Webster College, 1966

A Thesis Approved on

$\frac{\text { luen } 27 \cdot 81}{\text { (Date) }}$

By the Following Reading Committee

Carol Dowell, Thesis Director

Joel GoYastein

Mary K.'Tachau

Dean dr Chairman 


\section{ABSTRACT}

This thesis seeks to examine the role of the Democratic Party organization in Louisville, Kentucky and its influence in primary elections during the period 1933 to 1963. A prominent party leader, Lennie McLaughlin, is the focal point of the study.

McLaughlin was one of a few female party leaders who functioned as a party "boss" in a metropolitan area during that time.

Included is an historical narrative of Louisville's Democratic organization during the McLaughlin era and an analysis of her organization's success in the selection of favored primary candidates. The Democratic organization's accomplishments in general elections are compared to contemporary general elections in the same locale.

It is shown that during the McLaughlin era the organization controlled primary contests. The research further reveals that during the period 1933 to 1961 the normal voter turnout in local elections was above $60 \%$ and roll-off within an election remained consistently low. Comparative data from 1973 and 1977 local elections are analyzed. 


\section{ACKNOWLEDGMENTS}

The author gratefully acknowledges the guidance and assistance of Professors Caro1 Dowe11, Joel Goldstein and Mary K. Tachau. She wishes to express thanks to her family and friends who have been constant support. She is indebted to those persons who were the subject of interviews. The interest and assistance extended her by the staff members of the University of Louisville Archives and the Jefferson County Board of Elections is greatly appreciated. She extends her gratitude to Madge McDonald LeDonne for her editorial and typing assistance. Special gratitude and appreciation goes to her husband Tom whose encouragement motivated the endurance to complete this thesis. 
TABLE OF CONTENTS

Page

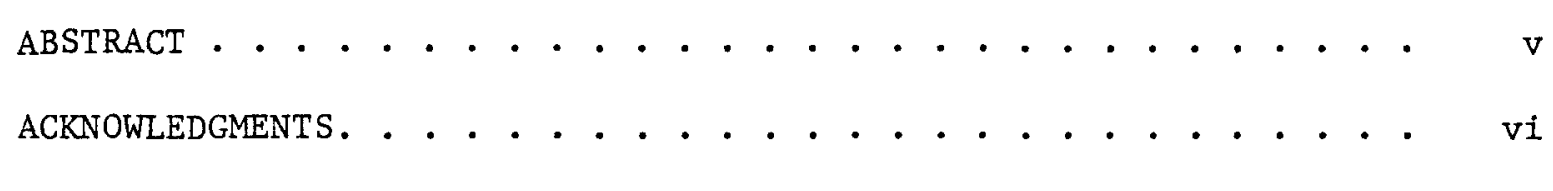
CHAPTER

I INTRODUCTION . . . . . . . . . . . . . . . . I

II REVIEW OF THE LITERATURE . . . . . . . . . . . . . . 3

II I LENNIE MCLAUGHLIN AND THE DEMOCRATIC ORGANIZATION. • . . . 19

IV LOUISVILLE'S DEMOCRATIC ORGANIZATION: PERFORMANCE IN SELECTED PRIMARY ELECTIONS . . . . . . . . . . . 83

$\mathrm{V}$ CONCLUSION . . . . . . . . . . . . . . . . 134

APPENDIX . . . . . . . . . . . . . . . . . . . 148

REFERENCES . . . . . . . . . . . . . . . . . . . 157

VITA . . . . . . . . . . . . . . . . . . 166 
CHAPTER I

INTRODUCTION

Political organizations in the local milieu are not unlike other types of organizations. There are leaders and followers. The organization has goals. If the organization intends to accomplish specific goals, there are acceptable methods of behavior and functions necessary for success.

There is information about the nature of local political organizations. In the past, such studies have included descriptions of party "machines" and party "bosses." The accomplishment of a local political organization's goals has been analyzed in terms of patronage, government's legislative and administrative functions, the nomination process and voting behavior, among other factors.

One of the purposes of this study was to describe the recent history of the Democratic party organization in Louisville, Jefferson County, Kentucky using as a focal point Mrs. Lennie McLaughlin. McLaughlin was a party leader from 1930 to 1964. She was selected because of her influence in and her leadership of that local party, and because she was a woman who led a metropolitan political party. Thus, a second purpose of this study was to relate the story of one woman who was unique in her role as a partisan leader who functioned as a local political "boss." Her success as a "boss" is measured by her ability to control the Democratic party's process of nominating candidates for local public office. 
A third purpose of this study was to analyze in a comparative manner local voting behavior. Data from the period 1933 to 1961 was analyzed in comparison to data from the period 1973 to 1977 . The analysis centered on the concepts of voter turnout, rol1-off ${ }^{1}$ and the percentage of the total vote garnered by Democratic and Republican candidates for local offices. Select primary and general elections in Louisville and Jefferson County during these periods are cited in the narrative and in the analysis sections of this study.

Lastly, a major purpose of this study was to present in written form an account of a portion of Louisville's history so that it might be accessible and useful to other interested persons.

Political science as a discipline has changed over the years in the sense that emphasis of study has changed. The era of legal interpretive studies and historical approaches to areas within the field of political science have merged and evolved into behavioral and statistical approaches.

This research was undertaken to take advantage of both the older and newer approaches in political science. It is a political history of a particular local party and the impact on it of a particular personality who happened to be a woman. Such a study with an historical perspective can reflect generalities of the period through which the activities are observed. Freshening basic political science data with narrative and impressionistic approaches often can give the human picture of functions and behavior in the broad field of political science.

${ }^{1}$ The total vote of one race in relation to the total vote of another race within the same election: In general, "Incomplete ballots cast." Walter D. Burnham, Critical Elections and the Mainsprings of American Politics. New York: Norton, 1970, p. 114 . 


\section{CHAPTER II}

REVIEW OF THE LITERATURE

Scholarly attempts to describe and analyze political party leaders and the functions and activities of political parties have been undertaken. There were attempts to study the nature of political "bosses" and their rise and decline as powerful leaders on the local level. There have been studies of the role of women in the political process. But there has been less attempt to describe the nature of a particular female political boss in a particular geographic area.

The 1iterature pertinent to this study is divided into three general areas:

1. studies of political organizational leaders or "bosses" and political machines;

2. studies of female participation in politics;

3. studies that describe the particular local political organization and activities of individuals in the Louisville and Jefferson County, Kentucky area.

The attempt to show that a particular female political activist was in fact a boss of a machine must reckon with these part attempts of analyzing what a "boss" is and "how it is to be female" in politics.

Studies of Political Organizational Leaders and Machines

The classic biographical treatment by Harold Zink (1930) presents descriptive accounts of twenty bosses, their backgrounds, personal characteristics, domestic, social and business relations and 
their rise from novice to "boss." As his sources, Zink used newspapers, memoirs, public documents, political histories and interviews.

The study presents several basic characteristics and behavior patterns of the bosses.

1. Relationship between racial stock of the bosses and the dominant racial groups of foreign origin in their cities;

2. Early loss of their fathers and early responsibility of being the "breadwinner" for the family and the holding of a variety of jobs as youngsters;

3. Lack of correlation in relation to the number of children in the family or the sequential ranks i.e., being the oldest or the youngest;

4. Majorities' origins being low economic families;

5. Positive correlation with long residency in the particular city, a "most important" similarity;

6. Majority having no formal education beyond elementary school;

7. Having better than average personal morality and sense of humor;

8. Lack of interest in reading, either books or newspapers;

9. Having sound common sense and being fairly incisive; and

10. The fact that many did not obtain great personal wealth. (Zink, pp. 1-24)

Significance of the Zink study was that it attempted to reveal the reality of the late nineteenth century and early twentieth century bosses rather than rehashing the often-told myths and propaganda of the muckrakers, whose cartoons typified the bosses as cigar-smoking, 
fat men wearing flashy rings and having toothy grins, similar to Cheshires. Zink attempted to study specific bosses rather than to discuss the phenomenon of bossism in general.

Several studies of political bosses published in the 1970 's gave a more biographical treatment to individual bosses. Alfred Steinberg (1972) wrote of bosses such as Ed Crump of Memphis, Frank Hague of New Jersey, James Michael Curley of Boston and Tom Pendergast of Kansas City, among others. He concluded that these bosses did not lose political power because of the growth of a federal welfare system and the New Deal, but in fact "grew stronger.. . because they became the distributors of these monies and determined who would get them" (Steinberg, p. 2). Steinberg concerned himself in this study with narrative accounts of certain bosses and how they obtained and maintained their municipal political machines, what circumstances surrounded their decline, and not with statistical or analytical interpretations.

A similar treatment of the relationship between political bosses and the New Deal is described by Lyle Dorsett (1977) who surmised that the New Deal did not bring about the demise of bosses but helped them with federal dollars and patronage.

Theories to the contrary suggest that President Roosevelt's New Dea1 programs did lead to the demise of the big city bosses and their machines (Johnson 1963; Annals 1964; Tugwel1 1968). The poor and working classes were no longer dependent upon the machine for fulfillment of their needs. Their theory was popularized by the novel The Last Hurrah ( $0^{\prime}$ Connor 1956).

Arnold A. Rogow and Harold D. Lasswell (1964) published an analysis of nineteenth and twentieth century bosses which characterized 
two types of bosses. One was the "game politician" and the other was the "gain politician." Partially using Zink's approach, Rogow and Lasswell explored the social, economic and psychological backgrounds of thirty specific bosses and theorized those factors which characterize the two types of bosses. The point appears to have been to prove that the Acton principle ("Power tends to corrupt") is not necessarily true in the case of either composite boss. These authors contended that "corruption is a function of the relations among a number of variables in the personality system" (Rogow and Lasswell p. 217).

The literature on political bosses which combines biographical information with generalizations regarding political machines includes anthologies and studies by Fred J. Cook (1973), Alexander B. Callow (1976), Bruce M. Stave (1972), Eric L. McKitrick (1972) and Robert K. Merton (1972).

McKitrick dealt with factors that allowed reformers' success and served to precipitate the decline of certain machines e.g., cessation of service to the machine's clients, the weakening of the machine's internal solidarity through power struggles and the inequitable distribution of spoils.

Merton discussed the boss and the latent functions of a machine as a "generic type of social organization" (Merton p. 28). His idea of the key function of a boss is one of organizing, centralizing and maintaining various fragments of power scattered in political organizations. Thus the boss can satisfy a community's diverse groups which may not be satisfied by other legal or cultural social structures. Cook studied political bosses such as Mark Hanna, Boss Tweed, Abe Ruef and the Tammany Hall Machine. He concluded that the political 
machine was a distinctly American institution and that a great proportion of political power in the United States is held by those who are not public officials. The American society which nurtured political machines and bosses grew in a rather rapid, unstable manner because of the sharp growth of urban areas in the nineteenth century which was characterized by a heavy influx of immigrants. Cook further suggests a long life for political bosses because there are still those who choose to make a full-time job of the profession of politics, that is, "the business of nourishing and managing a political machine" (Cook p. 145). In Callow's collection of primary and secondary sources, the entries range from Lincoln Steffens' reformist point of view on the subject, the role of the immigrant in the world of machine politics, Plunkit's philosophy of "honest graft," the rise of civil service and the decline of patronage, to the structure of the machine and the new style boss. Although Callow's view of bosses and machines tends to be perhaps unduly "upbeat" and positive, the entire collection of works takes the student through the nineteenth and twentieth centuries' landscape of literature concerning machines and bosses. It explores the broadest range of literature concerning the topics.

The nature and structure of the $10 \mathrm{cal}$ political machine has provided fodder for many writers and scholars. Some, such as Jerome S. Bruner and Sheldon J. Korchin (1946), have studied a particular election of a mayor-boss to show the functioning of a machine blended with official local government. Furthermore, their study discusses the voters' perceptions of the boss-candidate and the machine, the relationship between party loyalists and the machine and the way the machine attracts voters. 
Other scholars such as M. Margaret Conway and Frank B. Feigert (1968) have observed the social characteristics of the precinct leaders of two local political parties in two different locales and the salient motivations of party activists.

A case study approach leads Edward N. Costikyan to attempt an explanation of modern urban politics based on his grass-roots experience as a Reform Democrat in New York City (1966). His writings on the mundane, shoe-sole activity of a party precinct worker (canvassing the precinct to register new voters, or dropping campaign literature at the door of each registered partisan), rings true to anyone who has done that mundane party work in the streets of any city. Costikyan's study has significance because it is a narrative description which synthesizes the ideas about party hierarchy and its check on public officials, the civil service bureaucracy (or the so-called "new machine" (see Lowi pp. 310-318), patronage as a useful governmental and political tool and the discretionary powers as the locus of corruption. His synthesis also includes the practical part of politics, that is, the role of the local political clubs, the campaign and candidates, the constituents, the vote totals, the margins of victory, and how one can rise through the ranks of the local party. Costikyan's ability to relate the theoretical and the practical makes the study a blend of thought and action.

Frank Kent's (1923) book is more like a story told by an experienced political operative than a sophisticated scholarly work. The tale is certainly not a fabrication, but a collection of the folkwisdom and fact associated with local political activity. It narrates a typical party hierarchy and its component parts, from the 
precinct official through the ward executive to the boss. Although Kent discussed the nature of candidates and campaigns, the most pertinent section relating to this study was that which succinctly and repeatedly described the importance of a primary election in terms of continuing the boss and the machine.

Primaries are really the key to politics... . Primaries are the exclusive gate through which all party candidates must pass. Control of that gate in any community means control of the political situation in that community (Kent p. 7).

Kent described the basic interdependence of each segment of a machine's hierarchy. To perpetuate itself, the parts of the machine must do what is expected of them respectively. Although the study contained no hard data, no footnotes, nor other of the niceties of scholarly works, it was full of information on how the political game works, according to Kent. With several grains of salt, to flavor some exaggerations, the student can picture the motivations and behavior of local politicians in the early twentieth century. This current study of a local political leader, Lennie McLaughlin, incorporated Kent's theory that party primary elections are the key to the maintenance of a successful party machine. This study depended heavily upon John Baker's (1971) notion that one important characteristic of the "old-style" machine is the control of public officials through the control by the machine of the nomination process.

Baker cited three other statements that describe a true machine:

1. a party organized with a disciplined hierarchy of a single executive or a united "board of directors"; 
2. party leadership having lower-class origins and not having status as public officeholders; and

3. material and psychic rewards motivating support of party workers and a core of voters (Baker p. 133).

But the emphasis of this McLaughlin study was on the ability of the party boss to consistently deliver the vote for his or her chosen candidates in the primary election to be successful and durable.

The boss was willing to lose an occasional election as long as he could maintain control of the machine and its patronage mechanism which would guarantee his success in the long pulI (p. 133).

A political "boss" has to be concerned with the "long pull."

\section{Women In Politics}

There is a growing body of literature concerning American women and politics. The majority of these works have been published in the last decade, most likely owing to the recent popularization of the woman's movement. To comprehend the uniqueness of this study's subject, one must view this brief survey of the literature and note the lack of literature on women "bosses" of municipal political machines or organizations, especially in the time in which the subject operated, 1930 to 1964. A few female party leaders are mentioned, though casually. None are treated extensively. The reason for such a lack of literature about women party "bosses" may we11 be because there were so few of them.

Gruberg (1968) observed the position of women in political

parties since the $1920^{\prime} \mathrm{s}$. He suggested that some women were recruited into official status by male leaders, but there was male resistance to women "invading" the political clubhouses.

These had been "hang-outs," places to play cards, chew tobacco, and drink. Some women have the disposition to fit into such masculine groups, and others have not (p. 49). 
But the real opportunity for a woman in a political organization came if she enlisted her help in an "off-year" rather than on the eve of an election, and if she served an apprenticeship at the precinct level. Of the authors cited, only Gruberg gave examples of women who had been considered party leaders. He mentions a Mrs. Halterman who was considered a woman "boss" in Missouri in the 1ate 1920's. He also cited Minnie Fisher Cunningham who was influential in Texas reform politics for about forty years. Gruberg called Dorothy Bell Lawrence, the first woman elected leader of a New York political club, a "boss." But he admits "there have not been many Mrs. Lawrences who are able to beat the men at their own game" (p. 69).

Constantini and Craik (1972) and Githens (1974) surveyed one thousand male and female political party leaders in California. Studied were legislators, party convention delegates and county party chairs. These authors used the Gough-Heibrun personality scales of the Adjective Check List (ACL). Respondents were asked to check the appropriate adjectives that best described them. Constantini and Craik summarized that women party leaders tried harder and worried more. Furthermore, they noted that fewer female party leaders than male leaders held a value for or, in fact, held public office, except on the local level (p. 230). The women surveyed had stronger party loyalty and had been active longer in party operations than had the men surveyed. But "for the women to assume elite status in the parties, she may be required to serve a longer period of apprenticeship than the similarly motivated male (p. 222).

Jane Jacquette (1974) collected several papers which had been presented at various meetings of the American Political Science Association on the topic of women and politics. These studies treated 
women's participation in the governmental bureaucracy, the court systems and political organizations, as well as presenting a comparative view of women in politics in developing countries.

Two entries in this collection were pertinent. Werner and Bachtold (1974) bemoaned the fact that sparse research had been done on the personality characteristics of women who achieved political leadership positions. In a search of Psychological Abstracts from 1928 to 1970 , the authors found "more under index entries under 'gold-fish' than under 'govt.-women'" (p. 75). Their study described the salient cognitive and temperamental traits of adult women in political office apart from women in general and elected males. The sample of women legislators showed "high scores on intelligence, dominance, adventuresomeness, unconventionality and radicalism (regardless of party affiliation)" (p. 83). Slight evidence of ego-defensiveness or anxiety in the women studied was revealed.

The second entry, Porter and Matasar (1974), took the tack of studying the involvement of women in the organization of Mayor Richard Daley of Chicago. They hypothesized that the Daley machine had previously excluded women but that, in response to the growing trend of female involvement, the machine included them either by making concessions to or co-opting women, just as the machine had done with blacks and other challengers. The authors abandoned the theory when they discovered that the Daley machine had changed little over the years, that some women had been a part of it, but were the "womanly women" in traditionally feminine roles and activities. These women generally went along with the machine. Few, if any, were close to being called a "petty boss," under the "great boss," Richard Daley. The authors never mentioned, however, Jane Byrne, the current mayor of Chicago. 
Githens (1977) edited a collection of more recent approaches to

the behavior of American political women. Githens purported that

"women political activists operating within the elite stratum may feel

greater experiential marginality" (p. 177). Political women are party

to two groups, women and politicians. There are conflicts inherent

in such dual membership.

Women who seek to enter the male-dominated political elite reject, whether they want to or not, at least some of the values and norms of most women. Like the Jew, the political woman no longer feels comfortable with nonpolitical women; she has problems engaging in informal conversation and in acknowledging other women's evaluations as criteria for her own self-esteem. On the other hand, the politician groups, where she wishes to establish contact, displays reticence in accepting her. The woman in politics thus finds herself isolated from both groups (p. 7).

If this theory of marginality and political women is to be believed, probing the theory as it relates to contemporary political women can only make this investigator appreciate the strains of isolation and duality that may have been the experience of politically active women prior to the popularization of the women's movement. This investigator suggests that it would be beneficial if more research were conducted in the area of the self-perceptions of political women in relationship to the theory of marginality.

Clarke and Kornberg (1979) studied the pattern of political recruitment and careers of both male and female political officials in four cities, two American and two Canadian. Their most striking finding was the homogeneity of family background of both male and female party activists, and the differential between the men and women surveyed and the public in general (p. 451). The authors' final conclusion was that the political party is not a fast or a great 
"escalator" for women who quest to be either a party "elite" (per the survey, candidates or party leaders), or an "insider" (an elite on the way up in the party). Of those surveyed, women party officials were disproportionately "stalwarts" that is, the middle leve1 management in the party organization which maintains the process from one election to another election.

Cotter and Bibby (1980) recounted women's involvement in the national Democratic and Republican parties. They concluded that it took about a generation from 1930 to reach the stage where party policy changes and strengthened roles of women in the parties were becoming obvious. During the period from 1968 to 1978 some goals were achieved, and the process continues.

Several studies should be noted in that they are pioneering studies of women in political activities.

Jennings and Thomas (1968) looked at men and women in the 1964 Michigan convention delegations to the national conventions. Jennings and Farah (1978) continued that sort of study by surveying the 1976 Michigan delegations.

Kirkpatrick (1974) analyzed women legislators on the state level, as did Mezey (1978). Kirkpatrick (1976) expanded on the previous studies of national convention delegates with her study of the 1972 Democratic and Republican national convention delegates. She noted that criticism can be made of using national conventions' female delegates as a cross section of American politically active women, but

It is not easy to identify a level of American politics at which women are sufficiently numerous that they can be studied not as idiosyncratic individuals, but as examples of a class ( $p$. xvii). 
Johnson (1980) in 1977 expanded and updated a previous 1975 survey of American women officeholders from local, state and federal governments to chart the trends of participation and to give aggregate descriptions of participants. Johnson concluded that:

Women tend to locate sources of discrimination within political organizations rather than in the electorate . . Except for districts in which women are the nominees of parties with little chance of winning, sex of the candidate has little relation to election outcome (p. 66).

Although studies such as Johnson's relate to elected women officials, certain insights can be gained to shed some light on the female party official as well.

Recent bibliographic and reference texts concerning women in American society in general and those relating to American women in politics must be noted.

Rosenberg and Bergstrom (1975) 1ist only four entries under the heading "Politicians-Party Activists." Rutgers University's publication (1976) is a biographic directory and contains some statistical analysis. Stanwick (1977) lists fifteen hundred entries in her collection of selected biographical sketches of American women political participants from 1950 to 1976. The subject of this study, Lennie McLaughlin, is not mentioned in any of these sources.

The Center for the American Woman and Politics at the Eagleton Institute at Rutgers University is to be commended for its efforts in sponsoring and publishing studies on the topic of women and politics. Future investigators will benefit from these efforts as the hiatus remaining in the research area is filled over time. 
Local Sources

Whenever an investigator seeks to gather information about a local personality to develop an in-depth study, he must depend upon a plethora of local resources. In this study it was especially true because the subject, Lennie McLaughlin, was a political party leader in a period twenty to fifty years ago. No significant work about her has been published in the intervening years.

Few official Democratic party records from the period remain on file at Louisville's Democratic headquarters. No such party records have been located at State Democratic headquarters in Frankfort, Kentucky. Several news articles were published in Louisville's newspapers, the Courier Journal and the Louisville Times. These articles were a major source of information concerning Lennie McLaughlin, the local Democratic party, the local primary and general elections and the campaigns which preceeded the elections.

Because of the lack of official party data and the possibility that news articles could contain inaccuracies or biases, it was necessary to gather and confirm information from persons who had been contemporaries of McLaughlin. Various interviews were conducted periodically over a two-year period. Fortunately, several McLaughlin contemporaries who had been privy to party activities and internal party decisionmaking were willing to discuss these matters, but all were unwilling to have their names used. The reason for anonymity given by most of these individuals was a fear of offending the subject. They realized Lennie McLaughlin is and continues to be a very private person who prefers not to be a subject of inquiry. Several interviewees suggested that Mrs. McLaughlin still has some influence in the local 
community, and they were worried that repercussions might result from McLaughlin's displeasure. Whether true or not, the perception of power and influence is almost as real as actual power and influence.

Several efforts made by the investigator or through intermediaries to arrange an interview with McLaughlin were completely unsuccessful. There were McLaughlin contemporaries who refused to be interviewed or were unavailable for personal and logistical reasons. The impressionistic data culled from those interviews that were conducted were, however, invaluable toward a greater understanding of the period and the subject.

The University of Louisville Archives and Records Center maintains an oral history collection of tape recorded interviews conducted in recent years with various subjects of local interest. Several such interviews were helpful, especially the series of interviews conducted by Professor Joel Goldstein with George Berry. Now deceased, Berry was the organizational chairman of Louisville's Republican party and was active in that party from 1910 until his death.

During the $1950^{\prime} \mathrm{s}$, Kentucky First Research, Inc. of Louisville periodically published Ken: The Magazine of Kentucky Affairs along with its regular financial and business oriented The Kentucky Report. One particular issue of Ken (November 1956) was invaluable because it was devoted entirely to the history of Louisville's Democratic party and the stories of prominent local Democratic leaders in the middle 1950's. One of the leaders covered was Lennie McLaughlin.

Certain governmental documents were basic tools of this study. Documents most often consulted were the official Election Returns maintained by the Jefferson County Board of Elections for the years 1933 to 1977. 
Finally, not only was this investigator unable to secure an interview with the subject, she was also unable to view any of the subject's personal papers, if such papers exist. No personal papers of Lennie McLaughlin have been discovered in the files of Louisville and Jefferson County Democratic headquarters. 
CHAPTER III

LENNIE MCLAUGHLIN AND THE DEMOCRATIC ORGANIZATION

Lennie Lee Walls McLaughlin, commonly referred to as "Miss Lennie," was one of a few Democrats who functioned as a party leader during the twentieth century in Louisville, Kentucky. She was a strong and durable leader of the local party and was unique in being the only female top official in Louisville's Democratic party. Her story and that of the other political actors and the circumstances of local history must be told to flesh out any analysis of her role as head of a party organization. McLaughlin's personal and political history is an important part of the total study.

Lennie Lee Walls was born at Sample, Kentucky near Hardinsburg in Breckinridge County, on June 1, 1900. Her father, Lee Wa11s, was born in 1856, and her mother, Mary Dorcas Walls was born in 1859 . Both died in 1928. Lennie was the youngest of eight Walls children, five daughters and three sons. Her brothers were Clovis (born 1878), Jesse (born 1880), and David (born 1822). Her sisters were Pearl (born 1876), Judith (born 1888), Carrie (born 1891), and Mary (born 1896).

The farm house at Sample burned in March 1900. Soon after, the family moved to Hardinsburg, the county seat, and occupied a simple frame house about two blocks from the county courthouse. 1

${ }^{1}$ Lennie Walls McLaughlin's niece, Mrs. Margaret Lyons, currently occupies the same house. The Walls family bible supplied most of the Walls family history for this study. 
Lennie Walls left Hardinsburg and came to Louisville to attend business school. She worked for the State Board of Health and also in a fundraising effort for the Kentucky Children's Home. ${ }^{2}$

Lennie Walls married William Lester McLaughlin on December 24, 1921 in Jeffersonville, Indiana across the Ohio River from Louisville. 3 Lester McLaughlin was born in Covington, Kentucky on April 14, 1895 and listed his occupation on the marriage license as a traveling salesman. Lennie Walls named her birthplace as Hardinsburg, Kentucky, her occupation as stenographer and her residence as Anchorage, Kentucky, the same location listed by her husband. (Anchorage is an old town very close to Louisville.) The license was issued on December 24, and the marriage was solemnized by the Reverend F. C. Andrews that same Christmas Eve. It was the first marriage for both Lester McLaughlin and Lennie Wa11s.

Within ten years of the wedding, Lennie McLaughlin had initiated divorce proceedings. The McLaughlins were divorced on December 20, 1930.4 The marriage was described by the plaintiff/wife as stormy,

${ }^{2}$ Helen Leopold, "'Miss Lennie' - The Woman Who Runs Things In City-County Politics," Louisville Times, March 19, 1952.

${ }^{3}$ Clark County, Indiana Marriage Record 57, p. 572. The town of Jeffersonville, Clark County, Indiana had traditionally been a town to which Kentucky residents went to elope or to marry and avoid a waiting period between the time of obtaining a marriage license and the actual ceremony. On the day Lennie Walls and William Lester McLaughlin obtained the license and were married, eleven of the sixteen license applicants were from Kentucky and most of them were from Louisville or Jefferson County, Kentucky.

${ }^{4} \mathrm{All}$ quotations and information regarding the divorce proceedings are taken from the court record, Linnie (sic) McLaughlin V. W. L. McLaughlin, Jefferson Circuit Court \#203484, Jefferson County, Kentucky. 
at best. Lennie McLaughlin accused her husband, who was a "traveling man" and only home on weekends, of treating her in a "cruel and inhumane" manner, especially during the last three to four years of the marriage. She claimed that Lester had a "drinking problem" and an "outrageous temper."

My husband attempted to strike me but once, but his daily abuse is just more than I can bear. . . He takes extreme delight in mortifying me before a crowd, until I hesitate to go any place with him. He not only quarrels with me, but will involve my friends.

One of Mrs. McLaughlin's friends, Mrs. Irene Chapman, declared in her deposition taken during the proceedings that the "defendant (Wm Lester McLaugh1in) never properly provided for his wife; she supported herself." Mrs. McLaughlin reiterated this view:

Although he was not supporting me he objected to my occupying the position or my working at the place I did, although I was working there when we married. Part of the time I was out of a position at the place I had worked and he didn't even give me money then and $I$ was compelled to go to my sister and get her to sign a note so I could pay my bills.

Lennie McLaughlin further accused her husband of seeing other women and generally being less than perfect. Lester McLaughlin denied all of his wife's accusations, but the judge awarded her the divorce. The McLaughlins had no children from the marriage. Lennie McLaughlin never married the second time. There is no mention of her marriage in the numerous news articles written about her, perhaps because the marriage had been dissolved prior to her prominence in the local Democratic party. Few of Lennie McLaughlin's contemporaries know anything about the marriage or her husband, others who may have some recollections preferred not to speak of them.

McLaughlin began her activity in Democratic party politics in Jefferson County when she became a clerk in Democratic state campaign headquarters. 
Miss Lennie started with the Democrats, working closely with the late Frank Dugan, then organization chairman in 1922. Next year she left the organization and went to work in the campaign offices of Alben $W$. Barkley who was running for Governor of Kentucky. Barkley lost to William Fields, the nominee who replaced Campbell Cantrill who had been nominated in the primary but who died before the election. But Miss Lennie gained a reputation then, as a pretty girl of 23 , for remarkable political acumen. ${ }^{5}$

Although Barkley was unsuccessful in that attempt, later, as one of Kentucky's United States senators, he was a strong supporter of McLaughlin. Through the years, the support was mutual. The Democratic party in Louisville with which McLaughlin became associated in the $1920^{\prime} \mathrm{s}$ had its roots in what was known as the Whallen machine. ${ }^{6}$ The organization's founder, Colonel John H. Whallen, was a businessman who ran a burlesque theatre on Jefferson Street and a saloon on what was then Green Street, later Liberty Street, in Louisville. - One of:John Whallen's earliest election successes was carrying all of the city's precincts in 1884 for the Democratic mayoral nominee, P. Booker Reed, whose campaign Whallen managed. Although Colonel John and his brother James Whallen, suffered a temporary setback in the 1895 election, the Whallens "put together what is now one of the last, if not the last, big-city political machines welded together originally in the Iong-gone gaslight era."7

The Whallen organization, otherwise known as the "Buckingham Theatre Gang" serviced Democratic citizens with the same social service functions common to party organizations of that era.

5 "Miss Lennie," Ken, November, 1956, p. 6.

'Thornton Conne1l, "'Organization' Has Been Down But Never Out," Courier-Journal, November 18, 1962.

7Thornton Conne11, November 18, 1962. 
Colonel John would dispense to the down-and-outer whatever the occasion called for - a bit of rent money, if that was the need, or a schooner of beer and a roast-beef-on-rye from the bountiful free lunch counter if the man was hungry. ${ }^{8}$

And as with other city machines, the Whallen organization used the very important tool of the beat police officer for keeping in touch with the people in the various neighborhoods of Louisville. During the Whallen years, the police officer, of course, was not employed under a civil service or merit system, but rather was a patronage employee. Police could be used on election day for "security" or for dealing with citizen voters, in either a positive or a negative manner! But the police officer also was used in the Whallen organization to transmit information about a current or potential voter who was in need of food, a job or a bit of coal for heat. The beat officer would walk the area as an emissary of the city and its public safety function and as an assistant to the party precinct official. ${ }^{9}$

Colonel John Whallen died in 1913 and did not live to see the Republican takeover of city hall in 1917 with the election of George Weissinger Smith who beat Democratic candidate Charles J. Cronan, Sr. ${ }^{10}$ World War I had drawn away from Louisville many of those upon whom the

${ }^{8}$ Thornton Connel1, November 18, 1962.

${ }^{9}$ Ed Carle, private interview, Louisville, Kentucky, 1979.

${ }^{10}$ Louisville city hall records show that a Republican, Robert E. King, became Mayor-Pro-Tem of Louisville in 1896. Another Republican, George D. Todd, was mayor from 1896 to 1897. Democrats followed until 1917 except for a one-year period from 1908 to 1909 when Republican James E. Grinstead was mayor following the raucous 1905 election court case, and a brief term as interim mayor in 1907 by Democrat Robert Worth Bingham. Louisville, Kentucky City Archives, "List of Mayors." 
Whallen machine depended for election victory, and Republicans were able to gather enough money to wage a successful campaign and defeat the Whallen machine.11 One of those Republicans, who together with $\mathrm{J}$. Matt Chilton and Robert H. Lucas conducted that success, was Chesley Searcy. Chesley H. Searcy, who headed the local Republican party during most of the time from 1917 to 1933, when Democrats regained control of city hall, had been trained in the art of politics by the Democratic Whallen machine. Shortly before 1900, Searcy was an office boy for the Whallens. Later he was a page in the state legislature. After local schooling and a stint at Vanderbilt University, Searcy returned to Louisville to study law. 12 He began working in the local Republican party in the period 1911 to 1915.13

Searcy must have learned much from the Whallens, but developed some techniques of his own. From the 1917 Republican victory until factionalism in the 1927 election caused his power to decline, Searcy was known to have at least two spies in the inner sanctum of the local Democratic party leadership. Neither spy knew the other's identity. Searcy kept close watch on his own Republican associates. He provided tips to the local news reporters, tips which sometimes publicly embarrassed the operative and thus gave Searcy reason to dismiss the lieutenant who had not played the political game according to Searcy rules.

1 Joe Hart, "Bosses Are Born - Not Elected," Courier=Journa1, December 11, 1938.

12 Joe Hart, December 11, 1938.

13 University of Louisville Archives, Oral History Collection, Tape \#61, George Berry, March 20, 1974 . 
It was not characteristic of Mr. Searcy alone, that for a first move in dealing with a promising young member of the organization, he would ask the youngster to do something wrong. Then, as one of Mr. Searcy's associates pointed out, it was little trouble to curb that person from then on, especially if the act was illegal. 14

Searcy continued to practice practical politics and maintained his Republican leadership until Republican Mayor William B. Harrison was elected in 1927. Searcy did not support Harrison. There is little doubt that Searcy "for many years before his death in 1935, was considered one of the most successful Republican leaders the State (of Kentucky) ever produced." 15

Before returning to a discussion of the fortunes or misfortunes of the Louisville Democratic party, one must mention the classic election controversy surrounding the 1925 local election to gain some understanding of the rough and tumble politics of the day. This electoral, and as it became, judicial episode exhibited some rather raw drama with as many twists and turns as a melodrama. 16

The 1925 Democratic nominee for Louisville mayor was W. T. Baker. Arthur Will, the president of the Louisville Board of Aldermen, the legislative body, was the Republican candidate. On Saturday before the Tuesday general election, as the daily newspaper, the Louisville Courier-Journal, was being readied for its Sunday edition, Republican leader Ches Searcy came to the newspaper's offices and stated his

14Joe Hart, "Bosses Are Born - Not Elected," Courier-Journal, December 11, 1938 .

15Joe Hart, December 11, 1938.

16 Various sources have been consulted regarding the $1925 \mathrm{elec}-$ tion; see, Thornton Connel1, "Organization' Has Been Down But Never Out," Courier-Journal, November 18, 1962; Joe Hart, "Bosses Are Born - Not Elected," Courier-Journal, December 11, 1938; Associated Press Obituary Sketch, Robert Worth Bingham, Courier-Journal and Louisville Times Library, Louisville, Kentucky; Jim Renneisen, "Elections of Long Ago: Fraud, Violence Come with the Ballot, but Few Voters Would Campaign For Change," Louisville Times, November 5, 1975; "Tracing Louisville's Past," Unpublished Lecture, Tom Owen, University of Louisville, November 13, 1977. 
intention to place a paid advertisement in the Sunday paper. His ad advised the public that the Democratic nominee, Baker, had once been a member of the Ku Klux Klan.

The newspaper had characterized the Klan as an unpatriotic and unAmerican institution. "Judge Robert $W$. Bingham, owner of the newspaper and a former mayor, by appointment, met the issue squarely. Baker was told he must withdraw from the race or face the consequences. Baker withdrew."l7 The Jefferson County Democratic executive committee selected Joseph T. O'Neal to replace Baker as the nominee.

Although $0^{\prime N}$ Neal gathered a large number of votes, the Republican Will was the apparent victor. But charges of fraud and an extended court action resulted in the Kentucky Court of Appeals in 1927 ruling "no election," and reversing a lower court.

Thus, Republican Will's election was thrown out, and Democratic Governor William Fields appointed the election day "loser," O'Neal to the mayoral post. "O'Neal replaced the Republican police and firemen with Democrats prior to the special election for the remainder of Will's term in November, 1927.18

The shenanigans of political arrests, including those of two members of the mayor's Honest Election Committee, and grand jury indictments of police officers on election interference charges did not help the Democrats. Not only did Republican William B. Harrison win the subsequent election for the unexpired term, but he went on to win a full four-year term in November 1929.

${ }^{17}$ Thornton Connel1, "'Organization' Has Been Down But Never Out," Courier-Journal, November 18, 1962.

$18 \mathrm{Jim}$ Renneisen, "Elections of Long Ago: Fraud, Violence Come With the Ballot, but Few Voters Would Campaign For Change," Louisville Times, November 4, 1975. 
What with the results of the $1925 / 27$ Harrison election, the

1928 Herbert Hoover Republican sweep and the 1929 election of Harrison

again as mayor, the local Democrats were dismayed.

The Democrats were so stunned and devastated that they closed their party headquarters, defected and in debt. A former

Louisville tavern owner, Michael "Mickey" Brennan came to the party's rescue. For several years, he paid the Party's expenses, kept the doors of the headquarters open, and put the Democrats back on their feet. 19

Brennan did not wait in the wings for a Democratic victory, but took hold of the remnant of the Democratic party during the lean times. Telling the story of Michael Brennan is to some extent telling the early part of the Mclaughlin story.

Michael Brennan was born in Louisville in 1877 , the son of Daniel and Lucy Hyde Brennan. After some formal schooling at Sacred Heart parochial grade school and in the city's public schools, Brennan was a plasterer's apprentice, a contractor, and finally a saloonkeeper. 20 Brennan never married, and at the time of his death in 1938 1ived with his two sisters in Louisville's east end.

Brennan's initial political activity was in his native Portland area of Louisville. He caught the attention of the Whallen brothers, as had Republican leader Ches Searcy.

He was taken into the Buckingham Theatre "green room" circle which included such political stalwarts of other days as Frank McGrath, Ed Tierney and Johnny Barry . . . Blue-eyed, fair-haired, smoothfaced, Brennan had the freshness of youth in this group of grizzled and battle-scarred veterans. Putting no trust in letters, telephones not yet in general

19 "Miss Lennie," Ken, November, 1956, p. 6.

20 National prohibition obviously caused a strain on Brennan and his saloon business; see "M. J. Brennan Dies at Spa," Louisville Times, November 25, 1938 and Joe Hart, "Bosses Are Born - Not Elected," Courier-Journal, December 11, 1938. 
use, tight-lipped and trustworthy, Brennan delivered highly confidential verbal messages and orders in person. Not only did he carry "the word," but he reported back on the manner in which it was received. 21

After the death of John Whallen in 1913, Brennan was closely associated with James Whallen and was with him during Whallen's daily walks in the downtown area. Brennan had many opportunities to learn from Whallen and to communicate and formulate his own political ideas and strategies. Brennan assumed leadership of the local Democratic party from James Whallen who was, like the local party, in poor health.

Brennan carried on the social service function of the Whallen machine. Christmas Day dinners were distributed to those in need, especially needy Democrats. Heaters, clothing, items for young children were all part of his donations to Louisville Democrats.

Mr. Brennan each day would fill his pockets with small bills to distribute among his needy acquaintances. He never turned down a request for aid . . . He would have an attendant at headquarters go to the bank each morning for $\$ 100$ in change to distribute to the needy. 22

His generosity stemmed from numerous motivations, certainly many of them political. But Brennan's personality has been described as one interested in helping those who, like him, had experienced hard times.23

Members of the Democratic remnant who were political advisors to Brennan in those lean times included Lennie McLaughlin, General Percy Haley, John F. Dugan (the son of the Whallen operative Frank Dugan), Patrick J. Welsh, Alben W. Barkley and Shackelford Miller, Jr.

2l"M. J. Brennan Dies At Spa," Louisville Times, November 25, 1938. 22Joe Hart, "Bosses Are Born - Not Elected," Courier-Journal December 11, 1938.

23 Joe Hart, December 11, 1938. Although Brennan appeared to like people, he was not interested in social entertaining. One newsreperter observed, "he (Brennan) disliked very much being alone for even a few minutes during his waking hours." 
Shackelford Miller, a native of Louisville, inherited political interests from his father, Shackelford Miller, Sr. who had been a party leader, a chancery and an appellate judge, and from his mother, Mary Floyd Welman Miller whose father had been Jefferson County sheriff. The junior Miller used his Harvard law degree in private practice with his father and his brother, Neville Miller, who was Louisville's mayor in 1933. Shackelford Miller, Jr. was the attorney who handled much of the local Democratic party's litigation in the state courts, especially cases connected with registration laws. Miller later was special counsel for the United States Government in local slum clearance and low cost housing projects. He was a judge of the United States Circuit Court of Appeals and chairman of the local Democratic party after Brennan's death.24 Alben W. Barkley, a native of Graves County, Kentucky had early experiences as a lawyer, McCracken County prosecuting attorney and county judge. He served as First Congressional District representative from western Kentucky, beginning the first of his seven consecutive terms in 1913.25 In 1927 Barkley began the first of his many terms as United States senator from Kentucky, terms which were interrupted by his service as Vice President under President Harry S. Truman. Barkley returned to the Senate in 1954, but his death in 1956 ended his lengthy, public service career.

Patrick J. Welsh was a native of Louisville's Portland area and a student of the neighborhood St. Patrick's parochial school. Later, he politically controlled what was then part of the ninth and tenth wards

${ }^{24}$ G. L. Willis, Kentucky Democracy: A History of Party and Its Representative Members - Past and Present, III, (Louisville: Privately Published, 1935), p. 84-85.

$$
25 \mathrm{G} \text {. L. Willis, p. 7-9. }
$$


of the city, the Portland area. Welsh was a close associate of Brennan and "according to those familiar with party affairs, deserves much of the credit for Mr. Brennan's success in restoring the party to a position of power."26 Welsh never held elective office, but was a patronage employee as assistant state tax commissioner. He had also worked for Camp Zachary Taylor and the Louisville \& Nashville Railroad. His political admirers considered Welsh a "brilliant statistician" and he is credited with initiating on the local level the practice of selecting a cross section of precinct vote totals to use in predicting the final election returns. ${ }^{2}$ Welsh became the local Democratic party chairman after the death of Brennan and the ouster of McLaughlin as party secretary in 1939. He died, however, a scant twelve days after his selection to that party post.

John F. Dugan, a Louisville native, received his political training from the Whallen organization and his father, Frank Dugan who was clerk of the Jefferson circuit court from 1915 to 1921 and chairman of the local Democratic party from 1921 until his death in 1926. John Dugan was a political patronage worker with the Kentucky Railroad Commission and later became organization chairman of the 10 cal party. ${ }^{28}$ General Percy Haley was more of a statewide political figure who is "remembered for one of the greatest political minds of his day." 29 Haley was a doorman at the state capitol and adjutant general of April 17, 1939.

26 "We1sh, Party Leader, Dies of Heart Attack," Courier-Journal,

${ }^{27}$ Courier-Journal, April 17, 1939.

${ }^{28}$ G. L. Willis, pp. $235-236$.

${ }^{29}$ Thornton Conne11, "'Organization' Has Been Down But Never Out," Courier-Journa1, November 18, 1962. 
Kentucky at the early age of twenty-five, at the turn of this century. During Woodrow Wilson's term as President of the United States, Haley was customs collector in Lexington, Kentucky, His patronage connections were statewide. He was considered a political advisor to Robert Worth Bingham, publisher of the Louisville Courier-Journal and Louisville Times. ${ }^{30}$ In 1956, a local publication retrospectively spoke of earlier times and cited persons in Haley's circle.

In the early 1920's Gen. Haley attracted a close-knit group of young men interested in good politics and good government. Among them were Dunlap Wakefield, who became sheriff (of Jefferson County) . . . ; Dr. Frank D. Peterson, now vicepresident of the University of Kentucky; Wilson W. Wyatt, who became Mayor of Louisville; Neville Miller, who also became Mayor (of Louisville); John C. C. Mayor, Jr. of Ashland, whose father once was head of the Kentucky Democrats; Vego E. Barnes, of Hopkinsville, now Commissioner of Economic Security in Frankfort, a post he has held 25 years; the late John R. Lindsay, who was Finance Director of the City of Louisville and later controller of the Courier-Journal; Tom Graham, now president of the City of Louisville Sinking Fund Commission in his eighth term and treasurer of the Louisville and Jefferson County Democratic Party; Lisle Baker, Jr. now vice-president and general manager of the Courier-Journal and Louisville Times. There were many others, and, of course Miss Lennie (McLaughlin) was among them. 31

Haley's political philosophy included the phrase, "give the people good government; it is the best politics."32 Practically, Haley's statewide contacts certainly gave an advantage to the local Democratic party, especially in those years when little local patronage was available. His later involvement with the national Democratic administration of Franklin Roosevelt proved beneficial to local Democrats.

${ }^{30}$ The friendship between Bingham and Haley supposedly dates from those early twentieth century Frankfort, Kentucky days.

31 "Miss Lennie," Ken, November, 1956, p. 7.

${ }^{32}$ Ken. November, 1956, p. 7. 
Lennie McLaughlin served as secretary of the Louisville and Jefferson County Democratic party during several of the years when Republicans were in control of local elective offices. She was the grass roots organizer and right-hand woman to Michael Brennan, who held the official title of organization chairman. Certainly, little glamour was associated with either her or his position prior to Democrats being in control of local government. State government was under Republican control after the 1927 election of Republican Governor Flem D. Sampson. 33 The government of the City of Louisville was also headed by a Republican with the election of Mayor William B. Harrison. ${ }^{34}$ Few resources were available to Democratic party leaders when patronage, legislative and bureaucratic influences were in the hands of the opposition party. Many persons who were involved in Louisville politics in the early twentieth century, however, remember some fellowship between Republicans and Democratic leaders. This does not imply that if Republicans were in power, they allowed Democrats all the privileges of patronage and other rewards. Still, there is an implication that in

${ }^{33}$ Sampson defeated Democratic nominee, John S. W. Beckham, a candidate supported by the local Democrats, such as Bingham. Prior to Sampson's election, Democrat William J. Fields had been governor, but the previous four years had seen a Republican, Edwin P. Morrow, as governor, elected in 1919. Thus, for almost two of the three four-year terms, Republicans held the Kentucky governor's office and were the majority in the state bureaucratic bipartisan commission system, wherein the majority party held control over what was the equivalent of executive departments.

${ }^{34}$ Republican mayors were George Weissinger Smith, elected in 1917; Huston Quinn, elected in 1921; Arthur A. Will, elected in 1925; and Harrison, elected in 1927 and 1929. A Democrat, Joseph T. O'Neal served as mayor for part of 1927 , because the Kentucky Court of Appeals overturned the Will election, and the Democratic Governor Fields appointment of $0^{\prime} \mathrm{Neal}$ until the special election of Harrison in 1927 for the unexpired term. 
certain ways such Republican leaders did assist the Democratic party that it survived to provide bipartisan electoral contests in the community. The same was apparently true when Democrats held local offices prior to 1917. One Republican party activist indicated that Michael Brennan and Republican leader Ches Searcy "were very close."35 That same activist suggested that

Mike (Brennan) went in the back door of Republican Headquarters as many times as $I$ went in the front . . . . leadership had honorable opposition while the underlings did the fighting. 36

A Democratic contemporary activist suggested, although anonymously, that Democratic leaders, when in power, often had a hand in the appointment of, or at least veto power over, certain Republican precinct captains. 37 Former Republican party chairman George Berry indicated that Ches Searcy helped pay the rent for Democratic headquarters prior to the 1932 national election, although Michael Brennan was publicly credited with such rental payments. 38

Berry offered his opinion that the Whallen brothers, who had trained both Brennan and Searcy, persuaded Brennan to stay in the Democratic party so that the Whallens could maintain control of both parties and still provide the community with at least two political parties and party primaries for local offices. Berry based his opinion of his first-hand knowledge on "what masterful politicians the Whallens were." 39

${ }^{35}$ George Berry, Oral History Tape $\# 62 \mathrm{~A}$, University of Louisville Archives, Oral History Collection, April 18, 1974.

${ }^{36}$ George Berry, Oral History Tape.

${ }^{37}$ Anonymous, private interview, October, 1979.

38 "Miss Lennie," Ken, November, 1956, p. 6; and "M. J. Brennan Dies At Spa," Louisville Times, November 25, 1938.

${ }^{39}$ George Berry, Oral History Tape $\$ 161$, University of Louisville Archives, Oral History Collection, March 20, 1974. 
It is quite possible that the top leaders of both parties could conduct personal relationships in an amiable manner, especially during the lifetimes of those who had shared the formative political experiences, such as Brennan and Searcy. Furthermore, it seems that these private arrangements of mutual support in hard times remained just that, private. The party workers in the electoral trenches were probably not aware of collaboration in the higher echelons of bipartisan leadership.

The hopes of the Louisville Democrats must have been buoyed in 1930 when one of their party, Marvel Mills Logan was elected United States senator. Then, in 1931, Democrat Ruby Laffoon defeated Republican William B. Harrison, Louisville's mayor, in the Kentucky governor's race. Democrat Albert B. "Happy" Chandler, a young relatively unknown from Corydon, Kentucky, became 1ieutenant governor that same year.

Michael Brennan supported Ruby Laffoon and received his reward in the appointment as a state revenue agent. Brennan "controlled considerable patronage. . . relating to the State Administration."40 Being state revenue agent meant that Brennan would receive compensation as well as patronage opportunities.41 A further opportunity for local Democrats to gain patronage and local control was pending the outcome of the local elections for Louisville's mayor and Board of Aldermen in 1933. Local Democrats were beginning to see the 1ight at the end of the tunnel of local Republican control.

40 Joe Hart, "Bosses Are Born - Not Elected," Courier-Journal, December 11, 1938.

41 "Brennan, Revenue Agent, Paid $\$ 22,582$," Courier-Journal, January 20, 1935 . 
Brennan's chief lieutenant in running the local Democratic organization during these years was the party secretary, Lennie McLaughlin. Her official role was that of keeper of party records of the Democratic executive committee. But her more important task was supervising the management of headquarters.

While Mrs. McLaughlin supervised the actual running of headquarters and was credited with a high order of generalship, she was not so well known by the rank and file of the party. Illustrative of that was a conversation heard recently in a cafe. "Mike Brennan is all right; you can depend on him, but that fellow, Lennie McLaughlin, he's no damned good," the disgruntled one said. ${ }^{42}$

But Brennan listened to McLaughlin's political advice, nonetheless.

With the Democratic successes of 1931, and the pending change in the national administration, the scene brightened for a local

Democratic takeover. Skirmishes for control of the local Democratic party and intraparty factionalism emerged. An incident in 1932 revealed a political struggle brewing between Michael Brennan and his followers and the camp surrounding E. Leland Taylor. These two factions squared off during the 1933 mayoral nomination.

Late in July 1932, a panel of federal judges ruled unconstitutional the previously enacted congressional redistricting act passed by the Kentucky general assembly. Thus Kentucky's nine representatives to the national congress were elected in 1932 on a statewide or at-large basis, rather than from the vote of congressional districts.

Democratic leaders from across the state agreed to form a slate of nine candidates which were supported in the various areas of the state. Brennan felt that because Louisville and Jefferson County contained a large number of citizens, two members of the slate should

42 Joe Hart, "Bosses Are Born-Not Elected," Courier-Journal, December 11, 1938. 
be from that area. He and his organization supported Charles Farnsley, a twenty-five year old attorney whose family had been active in local Democratic politics, as a member of the slate. Brennan allegedly agreed that E. Leland Taylor be the choice for the second spot. Brennan, of course, had to negotiate this arrangement with other Democrats from around the state.

Whether or not Taylor reneged on the arrangement or whether Brennan was only stringing him along, or, as a third possibility, the sttate slatemakers did not agree to two members from Jefferson County, Taylor ended up not being a member of the slate. Taylor claimed that the break with Brennan came when he (Taylor) "refused to throw his strength" with Farnsley and the seven incumbent congressmen. 43 Taylor attacked the leadership of the Democratic party with his campaign rhetoric. He wanted to purge the party leadership of such as "Mickey Mackey," a reference to Michael Brennan and Lawrence Mackey, the party's legal advisor, before that leadership could gain power in the local 1933 election.

Brennan's forces, on the other hand, accused Taylor of accepting Brennan's help during the early days of the campaign, but later turning and seeking the support of anti-Brennan forces, not supporting the organization's choice of Farnsley, and not being willing to pay his share of the cost of the slate. Democrats such as Eugene R. Attkisson, chair of the party's executive committee and Robert J. Hagan, an attorney and veteran Democratic leader, accused Taylor of believing that the area was only entitled to one congressional candidate,

43"Taylor Urges Party Purging," Courier-Journal, August 4, 1932. 
of not giving campaign donations to past Democratic races and of not participating open1y in Democratic politics. 44

In the meantime, a second slate was formed that included Taylor, Frank R. Goad of Scottsville and Charles H. Morris of Frankfort. Among other candidates not aligned with any slate was John Young Brown, Sr. of Lexington who had been speaker of the Kentucky House of Representatives during the prior General Assembly. Brown had the support of the Merchants Associations across the state. 45 The members of the Brennansupported slate were: incumbents Fred M. Vinson of Ashland, A. J. May of Prestonburg, Virgil Chapman of Paris, Voris Gregory of Mayfield, Glover Cary of Owensboro, Brent Spense of Fort Thomas, Cap R. Carden of Munfordville and newcomers Finley Hamilton of London and Charles Farnsley of Louisville. All of this slate won the primary except Farnsley. John Y. Brown, Sr. was the only victor who was not on a slate.

Farnsley did not carry Jefferson County in the vote count. Leland Taylor led Farnsley by about 2,200 votes. Nor could Farnsley beat Brown in Jefferson County. On the other hand, Farnsley led Taylor statewide by about 33,000 votes. But Brown beat Farnsley statewide by about 3,000 votes. 46 Because of the factionalism

44"Brennan Men Answer Taylor," Courier-Journal, August 3, 1932; and "M. J. Brennan Replies To Taylor's Charges," Courier-Journal, August 1, 1932 .

${ }^{45}$ Courier-Journal, August 7, 1932, p. 2.

${ }^{46}$ Jefferson County, Kentucky Official Election Returns, 1932; and "Brown Gains As Tab Nears End," Courier-Journal, August 12, 1932. Twenty-two Republicans and twenty-seven Democrats vied for their parties' nominations for Congress. 
involved in Jefferson County and because of Brown's and Taylor's popularity, Jefferson County did not have a representative in the Kentucky congressional delegation of 1932.47

The Taylor faction again challenged the Brennan organization in 1933 when Taylor ran against Brennan-supported Neville Miller in Louisville's Democratic mayoral primary. Miller won the office. 48 In 1935 Taylor battled with Brennan and Neville Miller for control of the organization. The June election of delegates to the state Democratic convention produced a fight between the two groups. During the legislative district meetings there were "many lovely braw1s." 49 But the Miller forces won a majority of the delegates. In 1937 Taylor was allegedly the person behind the weekly political organ, the Louisville Democrat, detailing a letter which stated that Shackleford Miller, Jr., the chair of the local Democratic party, had received $\$ 15,000$ in fees for representing a parking meter manufacturer who had been awarded a $\$ 60,000$ contract for city parking meters. Four libel indictments were handed down by the local grand jury against both James J. Hart, the Democrat editor and Moses Fort, its publisher. Hart

${ }^{47}$ The November general election resulted in a complete Democratic victory in the representatives races. Brown led the ticket in Jefferson County. The previous Third Congressional District representative, Republican Maurice H. Thatcher, was not on the Republican nine-person ticket in November.

${ }^{48}$ Chapter IV, this study, has a more complete discussion.

${ }^{49}$ Louisville Times, December 8, 1949. 
claimed he published the letter per Taylor's instructions, during a time when Fort was ill. Hart pleaded guilty to two of the indictments and received probated jail sentences and fines. Fort's indictment charges were dismissed. Taylor pleaded that the Hart statements were political. 50

The Taylor and Brennan factions did not make peace for years. On1y in 1945 was Taylor finally successful in an election when he became mayor of Louisville. But in spite of, or perhaps because of the vitality of factionalism in the 1930's the Democratic party was on the upswing in Louisville. Successful gubernatorial elections in 1931, 1935 and 1939, the senatorial contests of 1930, 1932 and 1938 , and the mayoral victories of 1933 and 1937 assured the local Democratic party dominance in that decade.

There were changes, however, in the Democratic party 1ocally. Three persons, who had been important to the continual functioning of the party, died within approximately a two-year'period. General Percy Haley died February 16, 1937, shortly after the devastating Louisville flood. 51 Robert Worth Bingham died December 18, 1938. Bingham had been Jefferson County attorney from 1903 to 1907, interim mayor of Louisville in 1907 and chancellor of the Jefferson Circuit

50"Two Heads of Weekly Are Named," Louisville Times, April 13, 1937; "Taylor Ordered Letter Used, Hart Says in Libel Case Plea," Courier-Journal, May 2, 1937; and Courier-Journal, May 18, 1937.

${ }^{51}$ Lennie McLaughlin had in her Democratic headquarters office a photo of Haley, eating from a tin can by candlelight in the CourierJournal newspaper building in Louisville during the flood. She also wore a ring made from his star sapphire tie pin and considered it a talisman during political campaigns; see, "Miss Lennie," Ken, November, 1956 , p. 7. 
Court in 1911. Bingham bought controlling interest in the Louisville daily newspapers in 1918.52 Bingham had statewide connections and contacts in the national administration of Franklin Roosevelt, who had appointed him ambassador to Great Britain in 1933. Bingham was an influential force in the local community and in the Democratic party, although many perceived him as an "independent Democrat."53

The death which affected the local Democratic party even more than the others was that of Michael Brennan on November 25, 1938. In the last few years of his life, Brennan had experienced the fruits of his support for Governor Laffoon and Lieutenant Governor Chandler in 1931. Brennan had assured Chandler of Jefferson County's 323 convention votes to give Chandler the nomination. In 1935, however, Brennan had supported Chandler's primary opponent, Thomas Rhea. In 1935 the Taylor faction had supported Chandler. That year Chandler lost Jefferson County, but won statewide. Thus, Brennan's patronage rich position of state revenue agent was abolished. But "later Brennan, whose organization was strongly represented in the Legislature, effected an accord with the Chandler administration."54 The rift was

${ }^{52}$ In 1918 Bingham bought controlling shares from General W. B. Haldeman, Miss Isabelle Haldeman and Henry Watterson, editor of the Courier-Journal. In 1919 Bingham purchased the last of the stock from Bruce Haldeman; see, Bingham's obituary, Louisville Times, December 18, 1937; and Courier-Journal, December 18, 1937 and May 19, 1948.

${ }^{5}{ }^{3}$ Willis, p. 46. 1938.

54 "M. J. Brennan Dies At Spa," Louisville Times, November 25, 
supposedly settled through a compromise worked out by Bingham, Haley, Brennan and Dan Talbot, Chandler's advisor. 55

Immediately preceding his death, Brennan spent the Thanksgiving holidays "taking the baths" at Hot Springs, Arkansas. Accompanying him were Lennie McLaughlin, Senator and Mrs. Alben Barkley and Shackelford Miller, Jr. Miller had left early to return to Louisville, but following Brennan's emergency surgery and subsequent death, he returned with Brennan's brother Edward to Arkansas. The entire group returned to Louisville with Brennan's remains. A listing of those who attended their arrival at Louisville's train station reads as a "Who's Who" in Louisville politics. 56

The news reports describing the death and funeral of Brennan rather dramatically asked the question which must have been on the minds of local practical politicians: "In the faces of all were written the unanswered question, who will be the next leader."57

The deaths of the "old guard" created a void. Emotional and political attachments, especially among Brennan and his followers, were strong. But with his death, the struggle for local political power ensued.

Lennie McLaughlin had been an important element in the continual operation of the local party organization in Louisville. She was extremely knowledgeable about the financial status of the party.

55 "Miss Lennie," Ken, November, 1956, p. 8.

56 "Brennan's Mourners Throng Train Station," Louisville Times, November 26, 1938.

${ }^{57}$ Louisville Times, November 26, 1938. 
She was the person who kept the classic political tool, the card index file of names and accompanying information about precinct and district workers, updated and operational.58 Had Brennan retired and lived a long life thereafter, McLaughlin might have become the heir to the party power, but there were others who desired such office and influence.

One of those seekers of political leadership and power was Louisville's mayor from 1937 to 1941, Joseph D. Scholtz. A native Louisvillian, Scholtz' parents had been political supporters of the Democratic party. After graduation from Cornell University in 1912 , Scholtz returned to Louisville and became vice-president of Denunzio Fruit Company, a post he held for at least ten years. He was appointed by Mayor O'Neal in 1927 to the Sinking Fund Commissioners and remained in that post under the Republican administration of Mayor Harrison. Scholtz was president of the Board of Park Commissioners in 1934 and was elected president of the Louisville Water Company in 1935. Scholtz followed Neville Miller in the mayoral office. Shortly thereafter Miller left Louisville. Miller's brother Shackelford, resigned his post as Democratic party chairman to become a federal judge. Thus, with Brennan gone and the Miller brothers removed from the local scene, Scholtz was able to gain control over the members of the local executive committee. McLaughlin had a very difficult time keeping all the political forces in line.

${ }^{58}$ Aaron Burr, who had been a New York Tammany leader, is credited with the introduction of the "device that came to symbolize modern organizing proficiency: the card index of voters' names." See, Ralph M. Goldman, Search for Concensus: The Story of the Democratic Party (Philadelphia: Temple University Press, 1979), p. 270. 
Two other factors caused consternation for McLaughlin. The Democratic state administration, headed by "Happy" Chandler was no political friend to McLaughlin. Secondly, the 1938 Kentucky senatorial primary pitted Chandler against Senator Alben Barkley, a close political and personal friend of McLaughlin. Even though Barkley won the race, the lively primary did not split the local party irreconcilably owing to the abilities and personality of Brennan.

But after his death, the Brennan conciliation factor was 1ost. Successor to Brennan as chairman of the Democratic executive committee was Patrick J. "Paddy" We1sh, the choice of Mayor Scholtz. 59 McLaughlin supported County Judge Mark Beauchamp for the post. Although Welsh had been a political friend of Brennan, McLaughlin had been "at variance with Mr: Welsh."60 The Welsh forces were pushing for McLaughlin's resignation. And Welsh planned to reunite all factions of the party, especially the Taylor faction, and hoped there would be no sides taken in state party primaries. But only twelve days after his selection as chairman, Welsh died. One of the "few surviving Democratic leaders here (in Louisville) who received his training under the Whallen Democratic organization" was gone and the struggle for control of the organization continued. 61

Within a week of Welsh's death, the Democratic executive com- : mittee selected as chairman Thomas F. Burke, the county tax commissioner. 1939.

59"Welsh Heads Democratic Committee," Courier-Journal, April 4, ${ }^{60}$ Courier-Journal, April 4, 1939.

61 "Welsh, Party Leader, Dies of Heart Attack," Courier-Journal, Apri1 17, 1939. 
McLaughlin opposed Burke's election as she had Welsh's. Her opposition was expected "for the reason she and $\mathrm{Mr}$. Burke have been at outs over a patronage dispute which occurred shortly after he was elected to his (Tax Commission) position."62 Because there were rumors that Mclaughlin would fight Burke's election, Scholtz and his supporters decided to push for her ouster as party secretary rather than allowing her to voluntarily resign. And even before the official dismissal and before Burke's official election, Burke lost no time making changes at party headquarters. He ousted Edward D. "Eddie" Briscoe, the office manager and replaced him with John F. Dugan who had worked at headquarters with Brennan and McLaughlin, but who had quit to join a Chandleraffiliated organization the previous year. Next on the line was McLaughlin. Burke was very clear on this matter.

My new secretary will be a big business man, one that everybody knows and one who will carry out office and organization orders to the letter. . . I'm going to run the place and I want people around who will help me, not try to be boss themselves. 63

There were some skirmishes before McLaughlin was relieved of her duties. The members of the Democratic executive committee who voted for the chairmanship were chosen in 1936. Their terms would expire in 1940 , the next opportunity for the party's reorganizational elections. Five of the eight comittee members voted for Burke to elect him chairman 64 Before the vote on McLaughlin could be taken, three of the members supporting McLaughlin left the meeting and prevented a quorum. No vote was possible. $18,1938$.

62"Burke To Be Democrat's Next Leader," Courier-Journal, April

63 "Burke Replaces Party Worker," Louisville Times, Apri1 20, 1939. ${ }^{64}$ Louisville Times, April 20, 1939. 
Burke was elected on a Wednesday. On that same day, unbeknown to the new chairman and his supporters, McLaughlin made a payment of advance rent in the amount of $\$ 10,500$ for party headquarters. After regular banking hours, McLaughlin met with J. G. McPherson, vicepresident of the Fidelity and Columbia Trust Company, the agents for the building in which headquarters was housed. The lease on the building had been executed in 1938 to run through January, 1942. The payment McLaughlin made paid the rent up to 1942.65

The next Monday, Burke was informed of the transaction. He was furious, especially since the rumor was that all known party funds had been used in the rental payment. He said he would not "tolerate headquarters employees who themselves want to be bosses.. . petty czars and straw bosses must go."66 Burke called a meeting of the committee for that evening to pass a resolution to vacate the office of party secretary, and proposed Lee Curry, Sr. as McLaughlin's successor.

McLaughlin claimed, of course, that she was protecting those such as Shackelford Miller, Jr. who would have been liable in the event of a broken lease. But she was prepared to submit her resignation and did so by the next day. The Monday evening meeting was postponed and her resignation was submitted prior to another meeting on Tuesday evening when a demand for such resignation would have occurred. This

65 "\$10,500 Paid for Rent 'Breaks' Democrats," Courier-Journal, April 21, 1939; and "Party Lease Tales Spiked," Louisville Times, Apri1 24, 1939 .

66 "\$10,500 Paid for Rent 'Breaks' Democrats," Courier-Journal, April 21, 1939 . 
delay enabled some members of the committee to avoid having to cast an embarrassing vote or not voting at all. McLaughlin's resignation closed "one of the bitterest fights within recent years for control of the party machine... . It represented a complete victory for Mayor Joseph D. Scholtz."67

McLaughlin's resignation statement said that she disagreed with certain policies of Mayor Scholtz, had thought of resigning immediately after the Miller brothers had left their elective and appointed party posts, but "at the request of a majority of the committee and the insistence of many members of the organization, (I) agreed to continue for a temporary period under the new organization." 68 She further contended that substantial funds were left in the party treasury after the headquarters advance rental payment. She felt an obligation to make good the Brennan pledge on the headquarters lease before money was used for other purposes. She indicated that a financial accounting had been given chairman Burke, a report approved by Burke and Mayor Scholtz. But she suggested that no previous request for such a report had been made of her by either Welsh, Burke or Sholtz.

At the Tuesday night meeting, Curry was not elected party secretary. Clem Theisen was elected to the party post about three weeks later. 69 He did not maintain his desk at party headquarters, however, but cared for official party correspondence from his private office. John Dugan continued as office manager at headquarters with Captain Edward Barnett as his assistant.

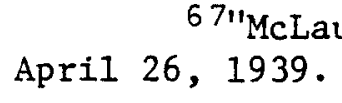

${ }^{68}$ Courier-Journal, April 26, 1939.

69"Theisen Handed Democrat Post," Louisville Times, May 11, 1939. 
Not only had McLaughlin put a scare into the new leadership with the rumors surrounding the matter of whether or not there were any party funds remaining, but she must have removed many of the party records upon her departure. No party records were left at headquarters, with the exception of registration records.

Just what had been in the files was a subject for conjecture, but $\mathrm{Mr}$. Dugan was of the opinion they were records of precinct workers... . Those records, it was conceded by several members of the committee are instruments of great potential damage, should they be used in building an opposing organization. 70

Although negotiations were begun to regain the records, it appears they were not successful. When the local party was electing precinct committee members in 1940 , there was still no list at headquarters of the incumbent precinct committee members from the time of McLaughlin's resignation in 1939.71 Such information, or lack thereof, certainly did not make the transition easy.

And so McLaughlin was on the "outs" of party officialdom.

The first decade of her official party leadership had been in the context of the primary leadership of Michael Brennan, and with friendly cooperation between party leaders and governmental leaders at city hall. Experience in the art of politics and organizational matters was an asset to McLaughlin in her future work in political campaigns and her eventual return to official leadership status. But on the first anniversary of her ouster, McLaughlin reflected upon recent party history.

${ }^{70}$ Joe Hart, "McLaughlin Resigns Post as Secretary," CourierJourna1, April 26, 1939.

71 "City-County Democratic Shakeup Due," Courier-Journal, December 3, 1940. 
McLaughlin, in a news interview, claimed that she had been "trying to get out of politics" but there were too many people who wanted her to stay. "People call up for advice because they don't seem to know to whom to tum." She described several factions within the party, all of whom were trying to gain control. While decrying the fact that there was not a leader such as Michael Brennan who knew the people, she did admit that she might have known the party people as well as he did:

Of course, when Mr. Brennan was alive, I caught most of the people who came to him asking for jobs or favors and was perhaps at times in closer contact with the organization than he was, but I always insisted that someone looking for a job should be able to fill it. That's the only way you can build up a good political organization. ${ }^{72}$

She claimed her secret for success was "knowing the right people and getting the right advice," and stated that she felt Mayor Scholtz and the current party chairman were not getting correct advice. ${ }^{73}$

The party chairman at that time was J. Blakey Helm, who had replaced Thomas Burke in early January 1940, after a split between Burke and Mayor Scholtz..$^{4}$ At the time of Helm's selection as party

72"Mrs. McLaughlin, on Ouster Anniversary, Says She Wants to Get Out, But People Won't Let Her While Democrats Squabble," Louisville Times, April 25, 1940.

${ }^{73}$ Louisville Times, April 25, 1940.

${ }^{74}$ The Burke-Scholtz split had repercussions in the 1940 Kentucky General Assembly legislative session in Frankfort, Kentucky, the capitol. One of Louisville's Senators, Frank Dacher admitted that bills which were associated with Burke passed while those with the Mayor's stamp on them failed. See, "The Public Suffers as Politicians Battle," Editorial, Courier-Journal, March 19, 1940. 
chairman, McLaughlin's supporters, clearly in the minority on the executive committee, had hoped that McLaughlin would be reinstated as party secretary. Such a move was unsuccessful. 75 Not only did the committee reject such a notion, but a piece of "ripper" legislation was drafted for introduction in the 1940 Kentucky General Assembly that would have changed the law regulating Jefferson County Fiscal Court's personnel appointment procedures. The proposed law would have eliminated the county judge's ability to break a tie vote in personnel matters after so many days. The plan of County Judge Mark Beauchamp and Fiscal Court Commissioner James $W$. Henning was to appoint McLaughlin to the position of County Treasurer when the incumbent Al Marret's term expired in April 1941. The other two commissioners, Ben E. Ewing and Robert A. Fihe were not supportive of McLaughlin's possible appointment. Judge Beauchamp would have been able to break such an anticipated tie vote. The proposed law was not enacted, but the skirmish showed that the dispute between the forces "around Thomas F. Burke, opposed to letting Mrs. McLaughlin get back into the councils of the Democratic Party" were still viable. ${ }^{76}$

The job which eventually was offered to McLaughlin was that of Fiscal Court Clerk, a four-year appointment. In June 1940, Beauchamp and Henning voted for McLaughlin while Ewing and Fihe supported the incumbent Clerk, Chester C. Wentzell. After a fifteen day tie vote deadlock, County Judge Beauchamp broke the tie and McLaughlin was named

\footnotetext{
${ }^{75}$ Joe Hart, "Mrs. McLaughlin May Get Job Back," CourierJourna1, January 1, 1940.

${ }^{76}$ Joe Hart, "Ripper Bill Believed Aimed at Mrs. Lennie McLaughlin," Courier-Journal, February 22, 1940.
} 
to the $\$ 3,600$ a year post. ${ }^{77}$ This was her first and only public, governmental job. The position did not provide much patronage to dispense, which gave her some relief.

I can hardly keep from chuckling when I tell favor seekers now that I can't help them get a job... . and I don't have to spend my days being "nice" to people whether I feel like it or not. 78

Such a sense of temporary relief might have been enjoyable, but not one suited to a partisan political operative. Patronage was a part of "mother's milk" in politics and government.

Some semblance of harmony descended upon the Louisville Democratic party in the period leading up to the December 1940 party elections of precinct committee people and legislative district members of the county executive committee. Pressure from the state administration of Governor Keen Johnson, through his surrogate and past campaign director, J. Lyter Donaldson, kept discord to a whisper. The governor's reminder was that the Democratic state central comittee had the final word on appeals from the local reorganization contests, and the threat to withhold patronage "plums" from the area until harmony was evident, was enough to lower the voices to a whisper. ${ }^{79}$

77 "Lennie Gets $\$ 3600$ Post," Louisville Times, July 9, 1940; and "Job Looms for Ex-Officer of Democrats," Courier-Journal, June 25, 1940.

${ }^{78}$ Marion Porter, "Miss Lennie Enjoys Breathing Spell After Years in Political Game," Courier-Journal, July 27, 1940.

${ }^{79}$ See, "Democrats' Reorganization Here Likely to Find Scholtz In Saddle," Courier-Journal, December 5, 1940; "Democratic Meetings Set," Louisville Times, December 6, 1940;"Democrats Expect Only 2 Changes," Courier-Journal, December 9, 1940; "Burke Holds Hour's Chat With Mayor," Courier-Journal, September 13, 1940; and, "Scholtz Holds the Whip Hand to Organize Party;" Courier-Journal, November 13, 1940. 
Throughout her first four years and the almost three years of her second four-year term as fiscal court clerk, McLaughlin was not totally removed from politics. In 1944 when J. Donald Dinning was chairman of the party and John F. Dugan was organizational chairman, there were rumors that several Democrats wanted former Mayor Neville Miller to return to Louisville from Washington, D. C. (where he had just left a job with the National Association of Broadcasters) to become head of the local Democratic party. The rumors appeared to be in reaction to then-Mayor Wilson Wyatt's and the party committee's plan to establish a twenty member committee to serve as a general coordinating body of the party. Miller reportedly felt that what really was needed in the local party was the equivalent to the positions previously held by Brennan and McLaughlin.

When during the Miller Administration, the boys in the trenches would show up at headquarters with that familiar old complaint that the police were raiding Democratic operators of handbooks and not molesting Republican bookies, Miss Lennie would flip registration cards out of her files to prove that Democratic and Republican bookies were being treated alike. Whether she convinced the complainers or not, she at least gave them the satisfaction of providing a place where they could do their griping and get it out of their system. 80

If Miller had returned to Louisville political leadership, he would have reinstated McLaughlin as the person in charge of party headquarters. But Miller did not return as chairman.

McLaughlin's reappointment to the position of Fiscal Court Clerk in 1944 was not devoid of politics. By that time there were two Republican commissioners, E. P. White, Jr. and Edward Torstrick.

${ }^{80}$ Robert L. Riggs, "Neville Miller Is Reported Sought As Head of Democratic Party Here," Courier-Journal, April 4, 1944. 
After the bitter debate which extended over several days, the vote resulted in a tie, with the two Republicans voting for Mrs. Rose Steiden and the Democratic County Judge Mark Beauchamp and Commissioner James Henning voting for McLaughlin. After a fifteen day deadlock, Beauchamp broke the tie and the appointment of McLaughlin was made. ${ }^{81}$

County Judge Mark Beauchamp sought reelection to a third term in 1945 , but was beaten in the Democratic primary by Edwin Willis. 82 There were more than 25,000 votes cast in that race. Willis beat Beauchamp by about a thousand votes. Reports indicated that McLaughlin's political expertise as manager of Beauchamp's political campaign was evident. She had at her disposal a war chest of money for the campaign. The vote results did not reveal a landslide victory for Willis. Beauchamp ran a "remarkable race as an anti-organization candidate for renomination." 83

Although Republicans were elected in the 1945 general election for county judge and fiscal court commissioners, McLaughlin was not removed from her position as clerk, mainly because of her four-year term and the probability that her dismissal would have produced legal complications.

The Democrats in Louisville had suffered losses at the hands of local Republicans in the 1940's. In 1943 the Republicans gained the

${ }^{81}$ See, "Fiscal Court Deadlocks on Clerkship," Courier-Journal, June 23, 1944; "Fiscal Court Storm Rages," Courier-Journal, June 26, 1944; and "Beauchamp Snorts 'Blatherskite' At White in Fiscal Court Deadlock," Courier-Journal, June 27, 1944.

${ }^{82} \mathrm{~A}$ complete analysis of this election is included in chapter IV of this study.

${ }^{83}$ Thornton Conne11, "Win or Lose, Beauchamp Owes Credit For Remarkable Race to 'Miss Lennie," "Courier-Journal, August 7, 1945. 
governor's office. That same year Republicans swept races for Louisville aldermen, city controller, two county commissioners and nine Kentucky General Assembly seats. In 1945, Republicans won the county judge's office and the third county commissioner position as well as about al1 other offices except mayor of Louisville. In 1946, Republicans won the United States senate slot with the election of John Sherman Cooper. In the eyes of the Democratic executive committee it all added up to the need for a change in party leadership. A governor's race was pending in 1947. Aldermanic races were to be held that same year, as were races for two county commissioner seats. During this period John Dugan was still organization chairman. "Correctly or not, many party stalwarts have expressed the view Dugan was unable to keep up the momentum of the Brennan-McLaugh1in organization." 84

Rumors began to circulate in party circles that McLaughin would be recalled as party secretary. Rumors also circulated that Dugan's current responsibilities would be halved, and McLaughlin would share responsibilities with John $W$. Crimmins. Crimmins had the support of Louisville's mayor, Leland Taylor who had appointed him earlier as the city's alcoholic beverage administrator. It seemed logical that the plan was to place McLaughlin and Crimmins at headquarters and thus satisfy at least two factions of the local Democratic party and provide an opportunity for harmony. McLaughlin, a "strong favorite of the committee majority and Crimmins, who has the Mayor's confidence and a reputation as an effective organizer, was intended to give all elements adequate representation in party headquarters." 85

\footnotetext{
${ }^{84}$ Joe Hart, "Party Reorganization Is Scheduled; Return of Mrs. McLaughlin Talked," Courier-Journal, January 8, 1947.

85 "Dugan Resigns Before Vote; Move Expected To Improve Feeling Between Party Groups," Courier-Journal, January 9, 1947.
} 
On January 8,1947 , the members of the Democratic city-county committee accepted John F. Dugan's resignation as secretary and organization chairman. The five members who voted for his ouster were Lawrence Wetherby, Robert Barry, Robert Fihe, Bernard Bax and Ward Lehigh. Three were in opposition to Dugan's ouster, John Barry, Joe Piazza and Nolan Fallahay. (Another member, Matthew Goetz was $i 11$ and not in attendance at the meeting.) Once Dugan's fate was sealed, the committee immediately recalled McLaughlin as party secretary and named Crimmins organizational chairman.

At the time of his ouster, Dugan commented about the need for what was good for the party, but did complain of the "inconsiderate" manner with which the affair was handled. Mayor Taylor admitted that leaks to the news media of the pending Dugan ouster, caused a more public discussion of the matter than might have been appropriate in his view. But Taylor frankly stated that "when a general loses battles, the army demands a change."86 But Dugan made one final "jab" at McLaughlin, in reminiscing the circumstances of McLaughlin's earlier departure from her party post in 1939 , by stating that the files and records of the party were intact and there were substantial funds in the party headquarters' treasury.

Why did McLaughlin have sufficient support to be returned to the official party position of party secretary? There is little doubt the losses to Republicans, especially at city hall and in the county courthouse, were major factors. Another is that Dugan had been a supporter of former Mayor Joseph Scholtz and there was some indication that the Taylor administration wished to make a fresh start with a

${ }^{86}$ Courier-Journal, January 9, 1947. 
coalition type leadership that included Democrats who had been active with Neville Miller, his brother Shackelford, and with Democrats in the Taylor camp. Another factor was that Earle Clements was readying himself for the gubernatorial nomination race of 1947 , and wanted strong Jefferson County support against his opponent, Harry Lee Waterfield, a supporter of "Happy" Chandler. The senior senator from Kentucky who had been a senator for twenty-one years was Alben Barkley, who had maintained a close relationship withMcLaughlin and provided her with one of her important connections with the federal government. ${ }^{87} \mathrm{~A} 11$ these factors and players provided an opportunity for Lennie McLaughlin to regain authority within the leadership of the local Democratic party. Because of past differences with former Mayor Scholtz, there must have been some delight for McLaughlin in one of the first moves of the executive committee during the meeting in which she was elected party secretary. Former Mayor Scholtz was touted as a possible federal appointee for the Louisville postmaster position. Retired Congressman Emmet 0 'Neal who had represented Louisville's third congressional district, indicated support for Scholtz but the executive committee of the local party endorsed Assistant Postmaster Herman Schmeing. Sholtz eventually got the position, but not before one of McLaughlin's supporters, Ward Lehigh made a trip to Washington to try to block Scholtz's appointment. 88

${ }^{87}$ Lennie McLaughlin had strong ties with federal appointees in Louisville's Federal Building. Patronage was available through the federal government's bureaucracy. See, "Dugan Resigns," CourierJournal, January 9, 1947.

88"Scholtz Opposed by 'Miss Lennie'", Courier-Joumal, January 10, 1947. Another news article stated that it was Dugan's involvement with Scholtz in the postmaster appointment that precipitated the committee's move to oust Dugan. See, "Taylor 0.K. of 'Miss Lennie' Rated As Last-Resort Move," Louisville Times, January 15, 1947. 
McLaughlin and Mayor Taylor were not privy to a lengthy honeymoon in their political alliance.

In party circles, the resolution protesting the appointment of Scholtz, which was adopted at the Dugan ouster meeting, was considered a direct slap at (Mayor) Taylor, who was known to favor the former Mayor. 89

And some draft legislation proposed by Taylor and his bureaucrats was not accepted for introduction in the Kentucky general assembly by the members of the Jefferson County delegation because it had not been approved by McLaughlin and Crimmins.90 At that time, legislators denied that all legislation pertaining to Jefferson County had to be cleared with Democratic headquarters. But interviews conducted with some of the contemporary legislators revealed that, in fact, such advance approval was necessary.

The honeymoon lasted long enough for the election of a Democratic Board of Aldermen (the "Dann Byck Board") and the election of Earle Clements as Kentucky's governor in 1947. Mayor Taylor's death in February 1948 intervened before an inevitable collision course between him and McLaughlin was "set in concrete."

The scenario of McLaughlin and Taylor was that of the classic political story of battle and respites, victories and defeats, one after the other. It was Taylor who defied Michael Brennan, McLaughlin's political mentor. It was Taylor who battled Neville Miller and McLaughlin in the mayoral primary of 1933, that ended with Miller's

${ }^{89}$ Courier-Journal, January 10, 1947.

90 The legislation would have allowed the City of Louisville to levy license taxes for its general expenditure fund rather than deposit the taxes or have them collected and distributed by the city's sinking Fund, a tax collection, debt service entity. 
victory in that race. It was McLaughlin who regained her party secretary position when arch-enemy Taylor was mayor of Louisville. And it was Taylor's death which led to the circumstances of a partial, albeit temporary, defeat for McLaughlin.

When a mayor of Louisville died, law required that the legislative body, the Board of Aldermen, choose a successor. After Taylor's death, political speculation about that successor began to appear in the newspapers. Almost every day for approximately two weeks prior to the board's election of a new mayor, names of potential candidates were floated in the newspapers. Interest groups and local politicians reacted to those names and positive and negative reactions were subsequently reported. Numerous meetings behind closed doors preceded the election. The final vote was extremely close.

The first name suggested by McLaughlin and Crimmins was that of Andrew Broaddus, a laundry company executive, previously president of the Board of Aldermen. 91 Broaddus, however, was opposed by labor. Then Tenth Ward Alderman Leo Lucas emerged as a possibility. Lucas claimed to have five sure aldermanic votes. (of the twelve aldermen, Third Ward Alderman Dann C. Byck was acting mayor and voted only in case of a tie. Sixth Ward Alderman Ben Ewing, former county commissioner, was ill with a heart condition.) On the fourth day of the scenario, Charles Farnsley was mentioned as a possible choice. ${ }^{92}$ On the fifth day, publicity was given to a legal opinion which stated that a sitting alderman was not eligible for being elected mayor. Farnsley, again, was mentioned as a possibility, but only among several other names. 93

\footnotetext{
${ }^{9}$ Courier-Journal, February 18, 1948.

${ }^{92}$ Courier-Journal, February 21, 1948.

${ }^{93}$ Courier-Journal, February 22, 1948.
} 
Two days later, Lucas withdrew his name from consideration in the interest of party harmony. Lucas was a "labor man" and he felt this factor might cause disunity during the upcoming congressional, senatorial and presidential races. At that point, attorney Eli Brown III, was touted as a leading contender with considerable strength among the aldermen. 94 Five days before the election, Thomas Graham, an investment broker was the supposed choice of McLaughlin and Crimmins, and allegedly Governor Clements was pushing behind the scenes for Graham. By the next day, the race was between Brown and Graham. McLaughlin was opposed to Brown. Her reasons were partly personal. Brown had been opposed to the appointment of her brother, David C. Walls, as United States district attorney. 95

That same day, reports from a private dinner at Louisville's Pendennis Club, where aldermen were meeting with Graham and the party's executive committee, were that labor was not happy with Graham. Three aldermen had formed a pro-labor bloc of votes. During that meeting, the party chairman received a phone call from Charles Farnsley who said that he would support whomever the organization backed for mayor. Other names still were being mentioned besides Brown, Graham and Farnsley. The Young Democrats organization sent to the aldermen a list of possible candidates. Charles Farnsley was one of four names included. 96 But the deadlock continued. Three days before the scheduled vote, the aldermen met in Acting Mayor Byck's office, but

\footnotetext{
${ }^{95}$ Louisville Times, February 24, 1948, and Courier-Journal, February 26, 1948 .
}

${ }^{95}$ Louisville Times, February 27, 1948. Brown had been the previous United States district attorney.

${ }^{96}$ Courier-Journa1, February 27, 1948. 
could reach no consensus. Leo Lucas said "no" to Graham and Brown. And outside that meeting, the AFL Central Labor Union executive board had a few choices, one of them being Farnsley. The National Association for the Advancement of Colored People (NAACP) was opposed to Brown and Graham.

McLaughlin and Crimmins continued to push for Graham with the legislative delegation to Kentucky's General Assembly. And McLaughlin predicted seven votes for Graham. 97 Others claimed, however, that here were only five sure votes for Graham, with two others if labor opposition was not too strong.

On the day of the election, March 2, in a premeeting closed caucus of aldermen, the vote was supposedly 6-5. Byck presided over the meeting; he would preside over the election meeting and vote only in case of a tie. Supporters of both Graham and Farnsley filled the aldermanic chambers in city hall. Alderman Ben Ewing was absent. 98 As the roll call vote reached the twelfth ward alderman, the count disclosed Graham with five votes and Farnsley with four. ${ }^{99}$ Twelfth Ward Alderman Nolan Fallahay cast his vote for Farnsley. His pivotal vote created a tie. Acting Mayor and Presiding officer Dann Byck broke the tie in favor of Farnsley. Thus Charles Farnsley was elected mayor of Louisville.

There is some irony that McLaughlin lost the battle to Farnsley since Farnsley had been Michael Brennan's choice for congress

${ }^{97}$ Courier-Journal, February 29, 1948.

${ }^{98}$ Some contemporaries of the event indicate that Ewing was more than happy to be away from the meeting; his illness, although possibly a serious matter, was convenient.

${ }^{99}$ Alderman Coomes, Specht, Lattis, Harlow and Siemens voted for Graham wile Alderman Reutlinger, Detrick, Lucas and Bossmeyer voted for Farnsley. 
in 1932, and was considered a Brennan supporter when Farnsley became a member of the Kentucky General Assembly in 1935. Farnsley lost his legislative position after opposing former governor and senatorial candidate "Happy" Chandler in 1940. But McLaughlin was for Graham, even though others might have been acceptable to her in the long run.

As a footnote to this story, one might consider which alderman "switched" and rendered inaccurate McLaughlin's original prediction that Graham would win the election. John Crimmins gave the best clue when he stated that his only "beef" was with Fallahay for "breaking his pledge."100

Despite the political maneuvering during Farnsley's selection, immediately after his election by the aldermen there was a tone of party unity in Louisville. Pledges of cooperation by Farnsley, Crimmins and party chairman McKay Reed were noted. McLaughlin said:

So far as I know the Democratic organization, for which I work, will not challenge the election of Mr. Farnsley, but will cooperate in every way with his Administration. Personally, he has my best wishes for success. 101

Various other party leaders such as aldermen who had opposed Farnsley and Thomas Graham, himself, sent congratulatory telegrams wishing Farnsley success and pledging unity.

${ }^{100}$ Louisville Times, March 3, 1948. A court case would later rule that an election would have to be held in 1948 to fill Taylor's unexpired term even though a mayor's race was scheduled for 1949. Farnsley won both the 1948 and 1949 contests.

${ }^{101}$ Thornton Connel1, "Farnsley May Be Known as 'The Peacemaker", Courier-Journal, March 4, 1948. The purported challenge would have been over the fact that a majority of all twelve members of the Board of Aldermen was needed to elect the mayor, one more than the six votes received by Farnsley. 
But, as usual in the local Democratic party, splits in the grand coalition were observable before the month of the mayor's selection was over. Aldermen Lucas and Fallahay and City Sanitation Department Director Joe Lannan, three of the political powers in the city's west end, were allegedly calling for McLaughlin's ouster as party secretary.102

The party's legislative district and precinct meetings during the quadrennial party reorganization in December 1948 provided a forum for a skirmish between Farnsley and the McLaughlin organization. Four vacancies on the local committee needed to be filled, and Farnsley slated four of his supporters against four endorsed by McLaughlin. The seven remaining candidates for the eleven member committee were supported by both groups. Two on Farnsley's slate won their districts, Alderman Ray Bossmeyer in the 43rd legislative district and Alderman Nolan Fallahay who was reelected in the 44 th legislative district. Two of McLaughlin's candidates won in their districts, County Tax Commissioner George Trager in the 37th legislative district and Alderman William Siemens in the 42nd district. 103

In spite of a weak effort to unseat both McKay Reed and Lennie McLaughlin, both were reelected by the newly formed committee to their respective posts of chairman and party secretary. John Crimmins was

102 Frederic C. Lord, "Miss Lennie' Ouster Talked As Race Wire Ban Defeated," Louisville Times, Marcy 19, 1948.

103 Thornton Connell, "Mayor Claims Victory; May Appeal," Courier-Journal, December 12, 1948. Those whom both groups agreed to were: 34th Legislative District, Lieutenant Governor Lawrence Wetherby; 35th Legislative District, County Commissioner Robert A. Fihe; 36th Legislative District, Robert E. Barry; 38th Legislative District, Bernard J. Bax; 39th Legislative District, State Alcohol Beverage Administrator Guy C. Shearer; 40th Legislative District, John J. Barry; and 41st Legislative District, Circuit Judge Ward Lehigh. 
reelected organization chairman and John Barry was chosen treasurer. And the 1948 party elections resulted in a "draw" in terms of the challenge between Farnsley and McLaughlin. 104

In early 1949, John Crimmins remarked that Farnsley and his advisors had cut off city hall patronage from party headquarters: "Headquarters and City Hall are more or less divided.105 But at the same time, some of Farnsley's advisors suggested that Farnsley run for the new four-year terms as mayor in 1949 without causing party rancor. The question they put to him was whether or not it was worth fighting the party organization and its leaders. Even though during the first few months, there had been intraparty bickering, there was not a totally negative relationship between Farnsley's people and the organization. Some advisors felt that cooperation with McLaughlin, Crimmins and Reed was an entirely realistic forecast, especially with Farnsley's popularity with Louisville's citizens. And so it was reported that Farnsley desired to run in the 1949 election as a "peace and unity" Democratic candidate for mayor.106

So began a most powerful period for Lennie McLaughlin as party secretary. Although decisions were made via consensus among the three

${ }^{104}$ Louisville newspapers editorialized that Mayor Famsley ought to be the head of the local Democratic party organization just as President Harry Truman was on the national level, and as Governor Clements was on the state level. See, "It Was the Voters Who Elected Farnsley," editorial, Courier-Journal, December 3, 1948; and "More Political Instruction In Store For Us," éditorial, Louisville Times, December 8, 1948.

${ }^{105}$ Courier-Journal, January 11, 1949.

${ }^{106}$ Courier-Journal, February 16, 1949. The same information was gleaned during interviews conducted for this study in 1980 . 
leaders of the party, McLaughlin, Crimmins and Reed, it was understood that at least two of the three had to agree on any major decision, and that McLaughlin allowed this type of consensus politics to occur. Had she disagreed, there would have been no consensus. Contemporaries of the trio suggested that usually McLaughlin and Crimmins agreed on a course of action, but Reed was the most independent of the threesome.

In 1952 the party was still controlled by the "tight political reins" of McLaughlin, Crimmins and Reed.107 That year's reorganization elections saw only two replacements on the county executive committee. And in 1955, McLaughlin was recognized for her organizational ability by being appointed to the advisory committee on political organization by the National Democratic Committee. The purpose of the advisory committee was to give voluntary help to state and local organizations in organizational instruction and resource development.108 If there were any visible splits in the local party in the $1950^{\prime}$ 's, they stemmed from the basic division in the state Democratic party between Albert B. "Happy" Chandler and the Clements-Wetherby coterie.

Chandler was elected Kentucky governor for the second time in November 1955. Harry Lee Waterfield was elected lieutenant governor. On the other hand, Earle Clements was elected to the United States senate in 1950. Although Clements was defeated in 1956 by Republican Thruston B. Morton, during the early fifties both Kentucky senators were Democrats. Alben Barkley, the vice president from 1948 to 1952,

107 Frederic C. Lord, "Little-Attended Democratic Meetings Leave Party Control In Same Hands," Louisville Times, December 9, 1952.

108 "Mrs. Lennie W. McLaughlin Named To National Advisory Committee," Courier-Journa1, September 14, 1955. 
won the second senate seat in 1954. After his death in 1956, Barkley's seat was won by Republican John Sherman Cooper.

While Chandler was governor and Republicans held the senate seats, the Louisville Democratic organization under McLaughlin was basically anti-Chandler. There was little, therefore, which the organization could expect to receive from the state administration. On the local level, however, the trio of McLaughlin, Crimmins and Reed was in control. Their candidates for city aldermen and mayor, county judge and county fiscal court commissioners were in power during the 1950 's.

Reorganization elections of December 1956 revealed a defeat for local Chandlerites and provided continued control of the party machinery by McLaughlin and her followers. In fact, the local Chandlerites pulled out of the contests when it became apparent in the precinct election for committee members that they were outnumbered.109 The new committee affirmed McLaughlin as party secretary, Crimmins as organization chairman, and McKay Reed as chairman. The committee chose Thomas Graham as treasurer and selected Arthur W. Grafton for the newly created post of legal counse1. 110

109 "Regulars Remain In Control of County Democratic Organization," Courier-Journal, September 14, 1955.

110 Members of the Democratic party executive committee in 1956 were: 34th Legislative District, County Judge Bert Van Arsdale; 35th Legislative District, County Commissioner Robert Fihe; 36th Legislative District, Charles Farnsley; 37th Legislative District, County Tax Commissioner Geroge Trager; 38th Legislative District, William H. Ising, Jr.; 39 th Legislative District, John F. Dugan, administrative assistant to County Judge Van Arsdale; 40th Legislative District, W. S. Milbum, president, Board of Aldermen and Principal, Male High School; 41st Legislative District, K. S. Stiles; 42nd Legislative District, Alderman William Siemens; 43rd Legislative District, Albert Steiger, Jr.: and 44th Legislative District, Raymond Bossmeyer. Farnsley and Bossmeyer had 
In the 1960 quadrennial party elections, there was no opposition to the eleven incumbent executive committee members. All were reelected. The same five officials, McLaughlin, et al., also were affirmed. This pattern of selecting the supporters of incumbent Democratic Governor Bert Combs (elected in 1959) occurred elsewhere throughout the state in 1960 .

Lennie McLaughlin's political dominance began to fade in the early 1960's in Louisville. Election of a Republican Jefferson County judge and a Republican mayor of Louisville in 1961 was, in effect, the beginning of the end for McLaughlin's power.

The primary campaign preceding the 1961 election witnessed several trial balloons floated by ambitious and potential candidates for local offices. First to float a balloon was Jefferson County Clerk James Queenan. As early as June 1960, Queenan announced he might run for mayor in 1961. Queenan was county clerk since 1949. His father, Frank, and his grandfather, Michael Queenan, were active in local Democratic politics. 111 Queenan found support for his potential candidacy in Governor Chandler who was preparing himself for the 1963 gubernatorial bid. 112

When Queenan first announced his intentions, McLaughlin took a "dim view" at that time, "due to the pending presidential and congressional races."113 She tended to favor former Mayor Charles Farnsley.

changed residences, making them eligible for chairmanships in different districts, although these men were incumbents on the committee. Fihe, Trager, Dugan and Siemens were holdovers from the last committee as well.

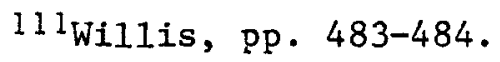

112 Louisville Times, February 8, 1961.

113 Courier-Journal, June 16, 1960. 
But, within a brief period of time, Queenan indicated that he couldn't buck the organization and that he was not running for mayor after all. Farnsley was unclear as to whether or not he would actually be a candidate. He would wait to see who asked him to run and then decide.114 But after the 1960 general elections were over, interest in the next year's mayoral contest perked.

In January 1961 , R. K. Walker led those who were candidates for the Democratic nomination by filing for the post. And in February, County Clerk Queenan, endorsed by Chandler, officially filed as well. By this time, the endorsement of the McLaugh1in organization had been given to William Stanford (W. S.) Milburn, president of the Board of Aldermen and principal of Louisville Male High School since 1931. Further, there was talk that County Sheriff Solon Russell would be a candidate. By the filing deadline all four men were in the race. Only Milburn had the official endorsement of the McLaughlin organization. Some political activists of the day suggested that Milburn was not the best choice of candidates for support, and inasmuch as Russell had been closely aligned with the "regular" Democratic organization in the past, his candidacy might have appeared as a viable alternative to Milburn. But the organization of McLaughlin and company continued their support of Milburn. 115

\section{${ }^{114}$ Courier-Journa1, June 27, 1960.}

115 Anonymous private interviews, Louisville, Kentucky, 1979 and 1980. See also, Louisville Times, February 8, 1961, which states Russell's patronage workers were suggesting that Milburn withdraw and the organization back Russell. 
The Republican mayoral primary in 1961 featured 39-year-old William 0. Cowger who was backed by the "regular" Republican organization. Cowger, a native of Nebraska who had come to Louisville in 1945 , was president of Thompson \& Cowger Mortgage firm. Cowger's only opponent was William Herbert Goepper, a 63-year-old retired Standard Sanitary Manufacturing Company executive, who ran on an antiorganization candidate.

The primary race for Jefferson county judge was also held in 1961. Republican candidates were Marlow Cook, 34 years old, an attorney and 34th legislative district state representative since 1957 , and Horace Barker, the former Jefferson county judge from 1945 to 1950, the entry of the Republican antiorganization group. Democrats had as one of their choices, Thomas L. Ray, 36-year-old majority leader in the Kentucky house in 1960 , state representative from the 35 th legislative district since 1956 and an attorney. The other Democrats in the race were Robert Alvin Vanmeter and perennial candidate Jesse Cecil.

The 1961 primary and general election for mayor and county judge showed many of the pending changes in local politics and Louisville's social fabric. The general election booted out all Democrats from city hall and the county courthouse. It was a year in which the question of race relations in the city and county was an important campaign issue. It was one of the years in which labor issues were an element in the campaign. And it was the year in which the Democratic organization was questioned about its ability any longer to provide the best primary candidates. Moreover it was the beginning of the end of Lennie Mclaughlin's control of the party machinery. 
The social relations between black and whites and the issue of equal access to public accommodations in Louisville were important issues prior to and during the primary and general elections in 1961 . Demonstrations in the streets of Louisville and "sit-ins" in some local businesses were held against a background of pending legislation concerning public accommodations being considered by the Louisville Board of Aldermen. 116 Early in the primary campaign, blacks and other interest groups wondered if Republican candidates would commit to such legislation during a Republican administration. (The 1959-61 Board of Aldermen was totally made up of Democrats.)

A subcommittee of the Republican Party's policy committeeone of 26 subcommittees - has the civil-rights question under study, according to party officials. Other than that, they were saying what the organization's candidate for mayor, William 0 . Cowger, says "I have nothing to say on it now, not even 'no comment." It seems obvious that the Republicans have not decided which way to go.117

Democratic mayoral candidate W. S. Milburn voiced the same "no comment" in response to queries about the possible rejection of organization Democrats by blacks in the upcoming primary. 118

It is difficult to determine whether or not in the early 1960's in Louisville a strong black vote existed for one party or another.

116 The 1960 proposed ordinance was eventually rejected by the Board of Aldermen on February 23, 1960. See, Louisville Board of Aldermen, Minutes. For a complete rendition of the saga, see, Board of Aldermen minutes for February 23, 1960, March 8, 1960, March 22, 1960, April 12, 1960, June 13, 1961, June 27, 1961, May 14, 1963, and November 13, 1963. See also, City of Louisville, Ordinance Number 63, Series 1963 and Ordinance Number 231, 1963.

117 Richard Harwood, "Democrats Showing No Concern Over Talk of Negro Revolt in City Election," Louisville Times, February 17, 1961.

118 Louisville Times, February 17, 1961. 
It appears that the black vote was divided politically as much as the white vote. Blacks in Louisville had not switched allegiance from the Republican party to the Democratic party as quickly as had blacks in other metropolitan areas. In the 1949 mayoral election, Charles Farnsley was opposed by black voters two-to-one. Democratic Mayor Andrew Broaddus received $44 \%$ of the black vote in 1954 . Democratic Mayor Bruce Hoblitzell received 46\% of the city's black vote in 1957. The question in 1961 was whether or not a strong position in support of civil rights would bring out enough black voters to counter the possible downside risks of alienating some white voters.

Even though demonstrations were occurring in downtown Louisville, candidates were campaigning on the public accommodations issue. Democratic leaders were touting the recent accomplishment of school integration, parks and swimming pool integration and employment integration in city and county governments. During a gathering of a black political action group called the "Non-Partisan Registration Committee," Democratic mayoral candidate, R. K. Walker made a "flat pledge to desegregate Louisville."119 The group was cool to candidate Milburn, warm toward candidate Cowger's remarks, but "it was Walker's speech, however, that dominated the symposium." 120

With the political and governmental inner circles considering the public accommodations ordinance, a mixture of good government philosophies, progressive racial policy and pure political expediency existed side-by-side. Prior to election year, the Mayor's Integration

\footnotetext{
${ }^{119}$ Louisville Times, February 25, 1961.

120 Louisville Times, February 25, 1961.
} 
Committee, a blue ribbon panel appointed by Mayor Hoblitzel1, had been meeting. Bipartisan representation included Republicans George Norton, William Harrison (son of the late Mayor Harrison), and Archibald Cochran as well as Democrats Barry Bingham, Sr. and John Hennessey. Democratic Governor Bert Combs often sent his representative to the meetings. City Consultant Roy Owsley represented city government during several of the meetings.

A committee report had been stalled during the summer of 1960 . A preliminary report had been drafted, but it contained some offensive language toward blacks, and so the group asked $\mathrm{Mr}$. Owsley to redraft a final report. The final report contained a rationale for the county government passing such a public accommodations law rather than the city which had a narrower jurisdiction. The report, a private document, was delivered to the clerk of the Board of Aldermen. But at the time of the defeat of the city's proposed ordinance, that report containing the signatures of committee members was not used. Speculation exists as to whether or not aldermanic president Milburn chose to ignore the report. The folkwisdom-consensus was that the Board of Aldermen would not have passed the ordinance, but the report would have provided a rationale to avoid a vote on the issue. Whether or not such a rationale would have satisfied the interest groups promoting the ordinance, however, is doubtful. But the political decision was made and the vote was held. Only one alderman, Eighth Ward Alderman Beckett, a black, voted for the law. 121

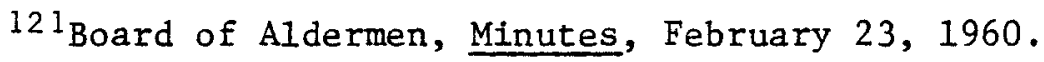


To several people who were active in the Democratic campaign, it appeared that Milburn was being perceived as a segregationist. During a press conference which dealt with the public accommodations question, Milburn stated that businesses should be operated in faimess to all customers served. But as the news reporters were leaving, he said that his public statement was one of a public official, but personally he felt that private businesses should be free to refuse service to or to pick certain customers. 122

On the other hand, Milburn also expressed fear that the cities would one day become ghettos for blacks and poor whites and that a caste system would develop. He publicly stated that desegregation was preferable to the development of that caste system. In that vein, his public platform included elimination of economic subsidies and tax advantages which might promote middle classes moving from city to suburbs. 123

Another campaign issue was the recession which had affected Louisvillians substantially.

More than 25,000 people are out of work - better than 8 per cent of the insured labor force. Negroes, proportionately, have suffered most from layoffs. 124

Democrats felt this issue would attract both black and white voters to the Democratic party and its traditional proworker policies. There was some labor support for James Queenan. His mayoral nomination filing papers had been signed by laborites Thelma Stovall and Norbert Blume.125

${ }^{122}$ Anonymous interviews, Louisville, Kentucky, 1979.

123 Louisville Times, April 21, 1961.

124 "Democrats Showing No Concern Over Talk of Negro Revolt In City Election," Louisville Times, February 17, 1961.

I 25 Queenan, in the meantime, was stating that he was not "Happy" Chandler's candidate, and had not solicited Chandler's endorsement. See, Louisville Times, April 4, 1961, and February 8, 1961. 
The May primary election concluded a campaign of vivid personalities and issues against a background of a city in the midst of social change. The McLaughlin organization continued to back candidate Milburn, although there were those who said that party chairman McKay Reed was the person who strongly supported his nomination. Those same observers felt that McLaughlin was not such an avid supporter of Milburn, but went along for the sake of party unity. 126

On May 23, 1961, Milburn was elected the mayoral nominee of the Democratic party. He gained $47 \%$ of the vote. Queenan was second, having received $41 \%$ of the vote. Solon Russell received $8 \%$ and $R . K$. Walker obtained 4\%. In the Republican primary, William Cowger received $72 \%$ of the vote and was the victor over Herb Goepper. In the race for county judge, the Democrats gave the nod to Tom Ray with $75.5 \%$ of the vote, over Robert Vanmeter's $21.5 \%$ and Jesse Cecil's $3 \%$ of the vote. Marlow Cook became the Republican nominee for county judge by garnering $73 \%$ of the vote. He beat his opponent Horace Barker who received the remaining $27 \% .127$

Republicans in Jefferson County had been building a strong, grass-roots organization for several years. That, coupled with the youthful, vigorous image of Cook: and Cowger, put Republicans in an advantageous position for the general election. There was consensus among the contemporaries interviewed for this study that Democratic mayoral nominee $W$. S. Milburn had a weak public image as a candidate. "He (Milburn) would make a nervous wreck of a public relations

${ }^{126}$ Anonymous interviews, Louisville, Kentucky, 1979 and 1980. 127 Republicans had primaries in all twelve of the Aldermanic races, while the Democrats had contests in Wards three and seven. 
counselor."128 Milburn had antagonized interests groups other than those concerned with racial issues. In the midst of the hard winter of 1960 , Milburn suggested that the city's relief program be discontinued because he felt that a city being that generous would be a target of "floaters and drifters." Milburn irritated civil libertarians in his recommendation that a Louisville Male High School teacher who had assigned reading J. D. Salinger's The Catcher In The Rye to students be transferred. Milburn annoyed the labor unions by refusing to proclaim "Union Label Week" during a stint as acting mayor of the city. His opinion was that to do so was commercial and served special interests. Milburn antagonized conservationists by endorsing a proposed Eastern Expressway route through two of Louisville's largest parks, Cherokee and Seneca. Milburn opposed coeducation in the public schools. So the question might be: Whom did Milburn not offend? Some were included in the $47 \%$ of registered Democrats who voted for him. But that percentage included not only those who supported him for his views but those who supported him as well because the McLaughlin organization said to do so.

A further question was whether that $47 \%$, composed of enthusiastic and less enthusiastic Milburn supporters, plus Republican defectors would come to Milburn's defense in the general election. McLaughlin's Democratic organization depended on precinct captains to get out the vote. And McLaughlin's organization may have been growing physically older and growing tired of one election after another. With the uncertainty of a strong core of support for Milburn's candidacy, the election brought apprehension.

${ }^{128}$ Louisville Times, Apri1 21, 1961. 
Republicans campaigned on the themes of throwing out of power the trio of Mclaughlin, Crimmins and Reed, electing a bright team of Cowger and Cook, and, within the city limits, the Republican promise of a progressive city government which would make Louisville a "mover and a shaker" in the field of economic development and social affairs. When the votes were counted after the November 7, 1961 election, William Cowger and a Republican Board of Aldermen had been elected. Cowger received $55 \%$ of the almost 130,000 votes cast. All twelve Republican aldermanic candidates won by each receiving about 9,000 more votes that the Democratic opponents. Marlow Cook became the Republican county judge with $56 \%$ of the countywide vote. In the City of Louisville, Caok received $54 \%$ of the vote. Even considering the approximate 1,000 vote roll-off in voters from the county judge's race to that for mayor further along the ballot, almost 2,000 Ray voters switched to the Republican Cowger in the mayor's race. Republicans admitted that they tried to woo Louisville's black voters to gain a victory. An analysis of the vote by ward in the city revealed that the west central area was important to the Republican victory. One could speculate that Democratic precinct captains of that area, defected to the Republican side.

There is no doubt that the Democrats at party headquarters severely felt the loss of city hall and county courthouse patronage. The election produced slow but steady call for change in the leadership of the local Democratic party. Certain factions within the party displayed a sense of separation from the McLaughlin organization. James Queenan and his labor backers were obviously buoyed with Queenan's showing in the primary. In 1962 Queenan came forward as the local 
supporter of senatorial primary candidate Harry King Lowman, a Chandlerite who was opposing Wilson Wyatt, Sr. Former Governor and United States Senator Earle Clements also supported Lowman. Wyatt won the primary election, but was defeated that fall by Republican incumbent Thruston B. Morton.

During this period, John Crimmins, left Democratic headquarters staff where he had been organization chairman to become United States collector of customs in Louisville. Lennie McLaughlin held on to her post as party secretary, although there were those calling for her resignation. 129 The party quadrennial reorganization elections of 1964 began to force the issue of whether or not McLaughlin should continue as head of the party's operation. With the losses to Republicans, party activists might have wondered whether it was good enough that McLaughlin could win the primaries with the Democrats of her choice. It was a matter of the Democratic margins in the city precincts not being sufficiently large enough to offset the Republican gains in the precincts outside the city limits. Some in the Democratic party asking those questions were younger members, ambitiously arriving on the scene. The party's "young turks" wanted to be a part of the Democratic power structure.

In 1962, Mckay Reed left his position as party chairman. Raymond Bossmeyer became chairman and teamed with McLaughlin in local Democratic party leadership. Mclaughlin's leadership during the 1963

129 "Democrats Dismayed," Courier-Journal, November 7, 1962. Sam Ezelle, the executive secretary-treasurer of the Kentucky State A.F.L.-C.I.O. was calling for reorganization of the Democratic party. See, Thornton Connel1, "Burke Is Backing Wyatt In Race With Lowman," Courier-Journal, February 7, 1962. 
primary election provided fodder for those in the party who were interested in removing her from power.

Two prominent Democrats were gubernatorial candidates in the 1963 primary election, Edward T. "Ned" Breathitt and A. B. "Happy" Chandler; Breathitt was supported by incumbent Governor Bert Combs. Chandler had the backing of Democrats active in the labor movement, among them 43 rd legislative district state representative Norbert Blume, business agent for a local Teamsters union.

Breathitt's Jefferson County campaign chairman was attorney O1dham Clarke. Clarke was well aware that McLaughlin remained neutral toward Breathitt in the primary, although at the last moment McLaughlin instructed her precinct workers to insert Breathitt's name in the preprinted sample ballots being distributed to the voters. But Breathitt won the election in both city and county precincts. "Breathitt quashed the move to oust Mrs. McLaughlin.. . with an arrangement which put some of his supporters on a special advisory committee, to work with the elected (county executive) committee."130 But a battle with McLaughlin was brewing. The Blume faction which included some who had supported Chandler in 1963, and the Clarke faction joined in 1964 to do such battle.

In 1964 Norbert Blume entered the Democratic primary for the office of third district congressman. His main opponent was Charles Farnsley, the former mayor of Louisville and the candidate supported by McLaughlin. It was important to the Democrats that they find a nominee who could beat a Republican in the fall race. Democrat Frank. Burke had

${ }^{130}$ Ivan Swift, "Blume Bloc Driving To Oust Miss Lennie," Louisville Times, June 11, 1964. 
lost the seat to Republican M. G. "Gene" Snyder in 1962. Farnsley won the primary with $49 \%$ of the vote compared to Blume's $45 \%$. A third candidate, Ed Jackson, gained $4 \%$, enough to drain away potential Blume votes.131 Blume was beaten by McLaughlin.

After the election, Blume began leading a group of Democrats called "Reorganization Democrats" in an effort to change the upper echelon in the local Democratic leadership. The goal was to gain enough legislative district chairmanships in the December 1964 reorganization party elections to have an edge in selecting a new executive secretary to replace McLaughlin and a new party chairman to replace Ray Bossmeyer. 132 There were those in the rump groups, however, who preferred to wait for party reorganization fights until after the fall general election and the hopefully successful races of Lyndon B. Johnson for president and Farnsley for congressman. Another group of Democrats itching for a change in the party heirarchy was that led by 01 dham Clarke. It is quite possible that Governor Breathitt supported this group's efforts of reorganization. Immediately prior to the winter elections for party offices, 01dham Clarke had become the spokesperson for the range of, people who wanted changes in party leadership.

The week preceding the party elections in December 1964, Ray Bossmeyer announced that he would not seek reelection as party chairman. Breathitt supported Thomas C. Carroll as Bossmeyer's replacement.

${ }^{13 l}$ One party activist involved in that race felt certain that, unbeknown even to Jackson, McLaughlin's organization got Jackson to run in the race for the very purpose of gaining the percentage needed to prevent Blume from winning.

132 Robert Deitz, "Blume-Led Rebels Rap Party Chiefs," CourierJournal, June 12, 1964. 
Carroll announced that an advisory committee would be established whose membership would include Lieutenant Governor Wilson Wyatt, Congressmanelect Charles Farnsley, State Representative Norbert Blume, former Congressman Frank Burke, O1dham Clarke, Victor Ewen, Mrs. Judy Bryant, Mrs. Maude Benboe, Democratic national committee-woman Mrs. Dann C. (Mary Helen) Byck, Secretary of State Thelma Stovall, and Mrs. Lennie McLaughlin.133 Carroll's move was obviously one of reconciliation. The unification effort to bring in all factions of the local party was completed when the legislative district chairmen were elected.

In 1964 six additional legislative district chairmen were elected, because of redistricting in 1962; seventeen seats were filled. The Clarke coalition slate included candidates in seventeen legislative districts. Incumbent chairmen associated with McLaughlin numbered eleven. The battle was on.

The executive committee was described as a

Largely paper organization. Its members have been chosen virtually without opposition according to the blueprint of the headquarters group dominated by Miss Lennie. And the party has been run largely by Miss Lennie and people close to her, rather than by the comittee . . . . for the first time in modern history, there is a full-scale bloodletting in a Democratic Party organization election. 134

The bloodletting turned out to be more private than public.

The party election resulted in victories for eleven chairmen associated with Clarke's coalition. But some of them were actually unanimous choices of McLaughlin, Clarke and Bossmeyer. When it was apparent the other six Clarke candidates did not have sufficient votes

\footnotetext{
133 Robert Deitz. "Bossmeyer Shuns Reelection Race," CourierJournal, July 7, 1964 .

134 Jack Ayer, "Democratic Donnybrook," Louisville Times, December 3, 1964.
} 
to win, those six readily gave support to the organization's candidates. There were only four districts that witnessed significant opposition candidates. 135 The fact was that the rebel Democrats did not win a majority on the executive committee and did not have the votes needed to oust McLaughlin as party secretary. Those who were familiar with the struggle to change leadership indicated that the battle from June to December of 1964 was more of a struggle between two personalities, Clarke and Bossmeyer. The election of Carroll as party chairman provided a partial resolution to the conflict between factions. It became evident there was a moratorium of sorts on the public discussion of intraparty squabbles. Even before the party elections, the public comments of McLaughlin, Blume and Clarke, when asked about the upcoming campaign, were identical, "We're all working together."l36 Even if the rebels had been completely victorious in December 1964, there must have been some twinge of apprehension about ousting the person from headquarters who knew all the precinct workers by name and knew the inner workings of headquarters operations so well. The new chairman, Thomas Carroll, asked that Lennie McLaughlin not quit her party post but stay on at least through the 1965 local elections, "since no one in the Democratic party could match the extensive and important precinct contacts she had built up during four decades."137

135 For the first time in the history of the Louisville Democratic executive committee, blacks were elected legislative district chairs, $\mathrm{J}$. R. Smith, a state representative, in the 42nd legislative district, and Mrs. Georgia Davis in the 40 th legislative district.

136 Robert Deitz, "Breathitt Is Guiding Party Here," CourierJournal, August 15, 1964.

137 Robert Deitz, "Miss Lennie Is Resigning," Courier-Journal, December 9, 1965. 
Be that as it may, in 1964 forty of the forty-eight city, county

and state offices in Jefferson County were held by Republicans.

In light of this Republican hold locally, all groups

working for reorganization of the Democratic Party agree

that to increase their power, some of these City and

County offices must be won by Democrats; and to achieve

this, a broad base of support within the party must be

found. No groups can be excluded, no faction ignored.138

This opinion emphasized the inevitable, that leadership had to change.

The events of 1964 implied that change meant the resignation of

Lennie McLaughlin and her replacement with "new blood."

Although the trend seemed inevitable, McLaughlin's public

comments were portraying a person who was blunt and determined not to

be fired from her party post, if she could avoid it. Reacting to the attempt of reorganization Democrats to oust her McLaughlin said,

"If they want to get rid of me, they know how to do it."l39 But for

the most part, McLaughlin was silent about purported attempts to find

state government employment for her.140 Even after the supposed

moratorium on intraparty squabbling had been lifted, there were few if

any public comments by McLaughlin. She became very low-key in late

1964 and early 1965. She was unanimously elected party secretary in

December 1964 and received a "standing ovation" from the Democratic

party executive committee members upon her election.141 But the trend

138 Robert Deitz, "Fight For Democratic Party Rule Simmering Here," Courier-Journal, November 22, 1964.

139 Robert Deitz, "Blume-Led Rebels Rap Party Chiefs," CourierJournal, June 12, 1964.

140 Robert Deitz, "Breathitt Is Guiding Party Here," CourierJournal, August 16, 1964.

141 RobertDeitz, "Democrats in Jefferson Reorganize," CourierJournal, December 13, 1964. 
was toward a change along with the recognition of the need to make the transition as smooth as possible. McLaughlin left her longtime association with the Democratic party leadership in her own style and on her own terms.

Lennie McLaughlin announced her retirement as party secretary on December 8, 1965. She had held that post from 1930 through part of 1939 and again from 1947 until her retirement. At the time of her retirement, the local newspapers editorialized her service to the local political party and summarized the changes which led to the end of the McLaughlin era. Her retirement was

Tacit acknowledgment that political fortunes have changed with passage of time, growth of population, and emergence of new generations moved by aspirations that differ from their forebears. 142

Changes in residential patterns and the rise of the suburbs, and the loss by the Democratic party of the singular loyalty of organized labor, racial minorities and other interest groups meant changes in the fortunes of local Democratic party politics.

Having been close to the machinery of politics and precinct reorganization for so long, Miss Lennie was impressed less by issues than by the capabilities of party workers . . . . The fact is that she was less sensitive to philosophies of government than to the hard currency of elections - party loyalty, patronage and the exchange of political obligations . . . As a walking directory of party workers, their foibles, limitations and capabilities, she will be greatly missed. 143

142"The Democrats' Doyenne Retires," Editorial, Louisville Times, December 10, 1965.

$143_{\text {By }}$ the end of January, 1965, the 1ocal Democratic Party's executive committee hired two part-time workers to replace Miss Lennie McLaughlin. Attorney L. Stanley Cahuvin, Jr. and insurance claims representative Richard Beliles were to be responsible for precinct organization, assistance in fundraising drives and general management of the party's local headquarters. 
Those who were contemporaries of Lennie McLaughlin all agreed, in response to interview questions about the matter, that Miss Lennie was surely a boss of the Louisville Democratic machine. Her retirement as party secretary marked the end of an era. Such was the transition from a tradition begun in the gaslight period under the Whallen brothers, continued through the years of Michael "Mickey" Brennan and ended in the turbulence of the 1960 's, a decade during which change was the keystone of society in general and in politics particularly. 


\section{CHAPTER IV \\ LOUISVILLE'S DEMOCRATIC ORGANIZATION: \\ PERFORMANCE IN SELECTED PRIMARY ELECTIONS}

Political folkwisdom is that it matters not whether a party leader always supports in the party primary selection process candidates who ultimately become the party's nominees. It is terribly important, however, that the party leader supports the candidate who wins in the district or geographical area in which the leader is perceived to be a leader. Additional folkwisdom suggests that being able to carry the district in a primary election is far more important than winning the general election and beating the opposition party.

If it is true that a legitimate political leader must be able consistently to obtain sufficient votes in his or her bailiwick of power to be considered leader of a political machine, it is appropriate to study the results of primary elections and discern a pattern of winning or losing.

Such a study was conducted for this research project. Certain primary elections were systematically selected from all primaries conducted between the years 1933 and 1963. Every third year was selected to vary the types of primary contests used. Because of the sequence of local, state and federal primaries in Kentucky, the procedure of using every third year assured a variety of races from the three levels of offices. Primaries in eleven different years were chosen. 
The position of particular offices on the election ballot was considered. For example, a race at the "top of the ballot" i.e., one which had higher visibility, was chosen as was one at the "bottom of the ballot," that had a lesser visibility. Thus, races for governor of the Commonwealth of Kentucky and for commissioner of agriculture were included. Races studied, assuming they were on the ballot in that particular year, were: United States senator, congressional representative, governor, commissioner of agriculture for the Commonwealth, county judge, county coroner, mayor of the City of Louisville and twelfth ward alderman for the City of Louisville. All registered voters in the county were able to vote for the first six races listed, whereas only those registered within the Louisville city limits could vote in the last two races.

This researcher determined which of the various primary candidates Lennie McLaughlin supported by gleaning news articles of the day and by conducting various interviews with political activists who were contemporaries of the subject. Official vote results from the particular races were analyzed to determine the percentage of votes gained by the candidates supported by McLaughlin.

The following is a narrative filled with bits of Democratic party history in Louisville, Kentucky, the history of Lennie McLaughlin in relation to primary elections, a selective recounting of her winnings and her losses in primary races, and some deductions by this author. The point of the narrative is to determine whether or not Mrs. Lennie McLaughlin was able to "carry" her candidates in the primary elections in the area of Louisville and Jefferson County, during her years as an official and an unofficial leader of the Democratic party. 
The decade of the 1930's opened with great promise for the Louisville/Jefferson County Democratic party.

Heralded by the election of M. M. Logan as United States senator in 1930 , by the election of Ruby Laffoon as Governor over Louisville's Republican Mayor Harrison in 1931, and by the election of Franklin D. Roosevelt to his first term as President in 1932, the organization's "mastery of the situation" reached a peak in 1933. I

The year 1933 was an extremely successful year for the local Democratic party. In the fall general election, the voters elected numerous Democrats. The local Democrats began a winning streak in local city and county office elections that was not broken until 1961, except during the years 1943 to 1947 when Republicans swept local offices. But during the remainder of the period 1933 to 1961 all Louisville mayors were Democrats. All of the Louisville Boards of Aldermen, the local legislators, were Democrats. The same was true for county judges and county commissioners. A majority of governors of the Commonwealth of Kentucky were Democrats. For Democrats in Louisville, 1933 marked the year of ascension from the slump created by Republicans in prior years.

The political struggle for local control was at a crossroads in 1933. Local Republicans had held the city's local offices since the 1910 election of Mayor George Weissinger Smith. Democrats wanted to wrest control of local offices from Republicans, while the Republicans attempted to maintain political control over the offices and their ensuing benefits.

IThornton Conne11, "Organization Has Been Down But Never Out," Courier-Journal, November 18, 1962. 
$\underline{1933}$

Slates of candidates representing various factions within both political parties set the tone for the primary election of August 5, 1933. Republicans were split into two groups, one representing the Carrell organization, the other the Ryans organization.

The Ryans organization opposed the administration of Republican Mayor William B. Harrison. The center of the Ryans group was Ches Searcy, the titular "boss" of the local Republican party. Searcy had been at odds with Mayor Harrison. When Harrison was elected in 1927 , Searcy's power declined.

The Carrell organization centered around Dan M. Carrell. Carrell's organization had supported candidate Harrison. The organization rose in stature as a result of Harrison's election.

In 1933 the candidates for the Republican nomination for mayor of Louisville were Dan M. Carrell, Charles W. Ryans, and Lucien D. Greene. Those running for the Republican nomination for Louisville twelfth ward alderman were Herschel A. Hooe, Rufus A. Hines and Arthur C. Funther. Republican county judge candidates were $C$. W. Samuels, Grover G. Sales, Joseph W. Cambron, Carl H. Denker, Stanley Briel and William F. Baumeister, Cambron and Briel were the major candidates. Republican candidates for the office of county coroner were Herman B. Stru11, Roy L. Carter, Fred L. Koontz and Louis W. Eckels. Carter and Koontz received the largest number of votes. Moreover, in 1933, the local Democratic party had two factions vying for the elective prizes. Groups which had the support of the head of the Democratic organization, Michael Brennan, supported mayoral candidate Neville Miller. Brennan's organization controlled the local 
Democratic executive committee. Miller's brother, Shackelford Miller was chair of the committee. Brennan's main lieutenant, Mrs. Lennie McLaughlin, secretary of the local party, was a supporter of Neville Miller. The support of the Brennan organization was a powerful endorsement since Brennan had many loyal "troops" following him, "troops" gained during the lean years of Republican domination.

The second Democratic candidate for the mayoral nomination was E. Leland Taylor who led a faction in opposition to the Brennan organization. Taylor had been at odds with Brennan since the 1932 congressional election. Taylor and Miller were the only Democratic mayoral candidates.

Democratic candidates for the office of twelfth ward alderman were Robert C. Weppner, William E. Banks, Charles T. Mathes, Watson A. Thompson and B. J. Campbell, Jr. Banks and Campbell gathered the largest number of votes. Democratic candidates for the office of county judge were Ben F. Ewing and Mark Beauchamp. John C. Clem, John M. Keaney, Charles G. Russman and Joseph Carr Ray were candidates for the office of county coroner. Keaney and Russman were major candidates.

The mayoral candidates Miller and Taylor, headed slates on the 1933 ballot. During the campaign Taylor accused Miller of previously calling tickets or slates undemocratic. But Taylor formed a slate himself in 1933. A newspaper advertisement of August 2, 1933 announced the Neville Miller (thus the Brennan organization) slate of candidates. The slate included Mark Beauchamp for county judge, Charles Russman for county coroner, and B. J. Campbell, Jr. for twelfth ward alderman. Other Miller slated candidates included two for county 
commissioner, two state senators, eight state house of representative candidates, eleven for alderman, one for police court judge, seven for judgeships, one for commonwealth attorney, one for county clerk, one for circuit court clerk, one each for sheriff attorney, tax commissioner, jailor and surveyor. 2 Leland Taylor suggested that "Brennan knew whom he wanted on the ticket and he put them on." 3

After a campaign which included street corner campaign speeches by various candidates, election day results were not known until after August 15, at least ten days after election day. This primary election appeared to be the first time the so-called "slow count" (or "courthouse method") was used. Counting took place at the courthouse rather than at the various polling places without observers. ${ }^{4}$ The head of tabulation of the vote for mayoral candidate Neville Miller was John S. Milliken. J. Harry Scales, Republican, and Mrs. Lennie McLaughlin, Democrat, were appointed chief tabulators by the local election commission. They were able to employ as many tabulators as were needed to count the votes in a quick and economic manner. 5

When counting was completed, Neville Miller's slate, with few exceptions, was victorious. Neville Miller's win over E. Leland Taylor was not a landslide. The margin of victory was a mere 667 votes, from a total of 34,765 cast. 6 Miller received $51 \%$ of the vote compared to

${ }^{2}$ Courier-Journal, August 2, 1933. ${ }^{3}$ Courier-Journal, August 2, 1933. ${ }^{4}$ Courier-Journal, November 11, 1945.

${ }^{5}$ Courier-Journa1, August 6,1933 . On that same election day, six people died in Kentucky because of rows in Clay, Breathitt, Floyd, Bell and Harlan counties. The National Guard was sent into Harlan county to guard the polling places.

6 Jefferson County, Kentucky, Official Election Results. Vote totals presented in this study were gleaned from the Jefferson County, Kentucky Board of Elections certified records. 
Taylor's 49\%. Miller-slated twelfth ward aldermanic candidate B. J. Campbe11, Jr. won that nomination with $48 \%$ of the vote whereas his nearest competitor, Taylor-slated William E. Banks gained $42 \%$. The other three candidates split the remaining percentage of the 24,524 votes cast. Miller-slated county coroner candidate, Charles G. Russman lost to Taylor-slated John M. Keaney by about 4,000 votes of a total of 33,406 cast. Russman also lost in the city precincts by about 3,800 votes. The $11 \%$ gained by another candidate, Joseph Carr Ray, made a substantial impact on Russman's total and the outcome of the election. The county judge nomination went to Taylor-slated Ben Ewing who gained $53 \%$ of the 35,208 votes cast. Miller-slated Mark Beauchamp lost in the City of Louisville and in the remainder of the county by approximately the same margin, 2,000 votes.

An analysis of the vote for these four offices indicated that the slate's mayoral and aldermanic candidates supported by Miller, Brennan and McLaughlin was successful in the City of Louisville precincts. The margin of these two victories was very slight. Millerslated county candidates lost in the city wards where McLaughlin and Brennan's organization should have had more influence. Had there been fewer candidates in the twelfth ward aldermanic race, Miller's Campbell might have been in trouble. 7

In summary, the organization supported by Lennie McLaughlin won $50 \%$ of the four offices analyzed. This percentage shows rather clearly that there were two evenly popular factions of the Democratic party in Louisville and Jefferson County in 1933.

${ }^{7}$ There is an old political saying that expresses a pragmatic view of vote totals: A11 a candidate needs is one vote more than any totals of the other candidates in a race; the rest is "gravy." 
The postscript to the 1933 primary electionwas, of course, the general election conducted on November 7 that year. Neville Miller, the Democratic candidate for mayor beat Republican Dan Carrell by gaining $51 \%$ of the vote. Carrell received about $48.5 \%$ while Socialist candidate Arthur S. Kling received near . $2 \%$, Socialist labor's Herman Hornung approximately $.07 \%$ and S.D.R.'s George C. Buckingham about $.2 \%$. Total votes cast numbered 129,021 . B. J. Campbe11, Jr., the Democrat, with 51\% beat Republican Rufus Hines and Socialist Elmer Landberg. All Democratic candidates for alderman had the same general victory margin of $51 \%$ of the vote. Republican aldermanic candidates received roughly the same $48.8 \%$ as did mayoral candidate Carrell. Close to 126,000 votes were cast in each of the aldermanic races. Democratic county judge candidate Ben Ewing beat his sole opponent, Republican Stanley Briel, by gaining $52 \%$ of the 148,272 votes cast. Democratic candidate for county coroner, John Keaney beat Republican Roy Carter by receiving $52 \%$ of the 147,901 votes cast.

$\underline{1936}$

August 1, 1937, primary election day, marked "Kentucky's first experience with a combined primary and general registration day." 8 Louisville had experienced registration for many years so no new registration was required of voters in the city. But elsewhere, even if registration had been in force, new registration was required. "Kentucky never had a general registration law before."9

${ }^{8}$ Courier-Journa1, August 1, 1936.

${ }^{9}$ Courier-Journal, August 1, 1939. 
Only two offices were on the Jefferson County ballot in the primary, United States senator and United States representative from the third congressional district. Because there was no presidential primary in those days, presidential electors were chosen in the - general election in November.

Five Democrats were running for the nomination of United States senator, a seat held by incumbent Marvel Mills (M. M.) Logan of Bowling Green, Kentucky. Logan had held that office since 1930 when he was appointed to replace Ben Williamson. Logan's only viable opponent for the nomination in 1936 was former Governor J. C. W. Beckham of Louisville. John Young Brown, Sr. of Lexington was also a candidate in that race.

Louisville's newspaper, the Courier-Journal endorsed Beckham. 10 The city administration headed by Mayor Neville Miller backed Beckham. while the Leland Taylor faction opposed him.11 Logan was endorsed by the state administration of Governor A. B. "Happy" Chandler. Chandler was lieutenant governor from 1931 to 1935 and was elected governor in 1935 with the support of the Taylor organization. Miller's organization opposed Chandler. The Democrats had what was called a "heated primary."12 Local newspapers indicated at the beginning of the vote count that the trends in Louisville held the key to Beckham's victory.13 On August 2, the day after the primary, Logan was leading Beckham with

${ }^{10}$ Courier-Journal, August 1, 1939.

${ }^{11}$ Courier-Journal, August 4, 1936.

${ }^{12}$ Courier-Journal, August 3, 1936.

${ }^{13}$ Courier-Journal, August 2, 1936. 
only 41 of Jefferson County's 621 precincts counted. On August 4, Logan had a lead of 3,100 votes with 285 precincts yet to be counted. By August 5, Logan had 2,550 votes over Beckham. Louisville and Jefferson County failed to give Beckham the lead he needed. The final Jefferson County vote for Logan was 19,914 or $41 \%$. The vote for Beckham was 22,731 of the 48,348 total, or $47 \%$. The Miller organization won the county for Beckham, but the statewide vote was not sufficient to claim a Beckham victory. John Y. Brown, Sr. received $11 \%$ of the Jefferson County vote.

In the other contest of the day, Democrat Emmet O'Neal gained $60 \%$ of the 44,649 votes cast in the race for third district congressman. Obviously, there was little contest. This race revealed little about a particular faction being ahead or behind in the election won-1oss column. The candidate was supported by a majority of the party activists. His total vote in the 1936 primary was 26,746 with three other candidates in the race. His vote total in the 1934 primary had been 14,733 with fifteen candidates in the race. The second ranked vote-getter in that race was Thomas A. Ballantine with 5,368 votes.14 It appeared that $O^{\prime} \mathrm{Neal}$ was a favorite of the majority of Democrats. An analysis of the senate race showed that the Miller administration and the organization in which Lennie McLaughlin played a key role were important in obtaining the Jefferson County vote for candidate Beckham. If one believes the maxim that it matters not who wins a statewide race as long as the organization carries the geographic district for which it is responsible, McLaughlin's group was successful.

${ }^{14}$ Future Louisville, mayor, Charles Farnsley gained 1,764 votes in the 1934 third district congressional race. 
The general election of November 3, 1936 witnessed Democrats

M. M. Logan and Emmet $\mathrm{O}^{\prime} \mathrm{Neal}$ win over their respective Republican opponents, Robert H. Lucas of Louisville and W. A. Armstrong. Democrats gained $60 \%$ of the vote totals. 15 Logan was able to beat Robert Lucas in Lucas' home county.

In the election of presidential electors, all Democrats from the nine congressional districts and the two at-large positions won in Jefferson County with an average of 85,000 votes compared to the Republican slate which generally received an average of 52,700 votes each.16 Vote totals for the Democrats sent to the electoral college were similar to those received by senatorial and representative victors. Strong, straight party voting in Jefferson County was revealed in 1936. $\underline{1939}$

The 1939 primary held on August 5 was a postscript to a turbulent spring in the Jefferson County Democratic party. Factiona1 infighting between Louisville Mayor Joseph D. Scholtz and those surrounding Lennie McLaughlin precipitated changes in party leadership and led to McLaughlin's ouster as party secretary in April 1939.17 Shackelford Miller resigned as party chairman to become a federal judge. His

${ }^{15}$ For those interested in the history of female candidates for public office, Sara Kasdan of Louisville, a Socialist party candidate for the third congressional district seat, received a meager 170 votes in this race. She outpolled Ferdinand Zimmerer, a Socialist labor candidate for the senate seat, who received only 94 votes countywide.

${ }^{16}$ Elector for the third congressional district who supported the candidacy of Franklin Roosevelt for the presidency was McKay Reed, a Louisvillian who became chairman of the local Democratic party in subsequent years.

${ }^{17}$ Details are described in Chapter III of this study. 
replacement, Patrick J. "Paddy" Welsh hoped to unite the various factions of the party, including that of Leland Taylor. Welsh was a worker under former Governor Ruby Laffoon and had been ousted from his state patronage post when Governor A. B. "Happy" Chandler was elected. (Chandler's gubernatorial successor was chosen in the 1939 election. He resigned to become a United States senator.) Welsh's tenure as chairman was brief since he died a mere twelve days after his selection. 18 Thomas F. Burke was named chairman of the local party through the active support of Mayor Scholtz. Scholtz wanted McLaughlin ousted. McLaughlin had a few allies on the party executive committee, but the tide turned against her remaining as a pivotal organization leader. McLaughlin's mentor, Michael Brennan, had died in 1938. Two important Democrats and friends of Brennan, Judge Robert Worth Bingham, publisher of the Courier-Journal and the Louisville Times, and General Percy Haley, a political strategist, died within a year or so of Brennan. McLaughlin's support thinned.

But following the death of Mr. Brennan, differences that had developed between Mrs. McLaughlin and such powerful figures as the Mayor (Scholtz) became wider without the conciliator influence of the former leader. Her resignation marks the end of a widespread move to wrest control of party affairs from her hands. 19

And so this 1939 primary was the first considered in this study during which McLaughlin worked for candidates in an unofficial capacity. 20 From the perspective of this research, this election could have been disregarded as McLaughlin did not hold official party leadership at that time, but her ability to "carry the candidates" in her political

18 Joe Hart, "Secretary Makes Fight To The Last," Courier-Joumal, Apri1 20, 1939.

19 Joe Hart, "McLaughlin Resigns Post as Secretary," CourierJournal, April 22, 1939.

20 McLaughlin remained a member of the Kentucky state executive committee of the Democratic party. 
bailiwick must have provided an interesting challenge to her. Her staying power was tested.

Democratic gubernatorial candidates were Keen Johnson of Richmond, Kentucky, John Young Brown, Sr. of Lexington and two minor candidates, Ulysses G. Foster of LeJunior and Charles Arnett of Louisville. Johnson slated Horace S. Cleveland of Franklinton as his candidate preference in the commissioner of agriculture, labor and statistics race. William H. May of Prestonburg was slated in that same race with John Y. Brown, Sr. There were three other candidates in the race.

Al1 Democratic incumbent Louisville aldermen ran with Johnson, including Twelfth Ward Alderman B. J. Campbe11, Jr. Charles R. Harris was the other candidate in that race, but was not slated with Brown. In the Republican primary, there was a rather close contest between gubernatorial candidates King Swope of Lexington and John Sherman Cooper of Somerset. Cooper lost to Swope in Jefferson County by more than 2,500 votes. Cooper gained $42 \%$ compared to Swope's $54 \%$ in a four-person race. Millard F. Creech of LaGrange, Kentucky was the Jefferson County victor in the commissioner's race, but lost statewide to Van B. Alexander of Cadiz. No Republican ran for the twelfth ward alderman's spot.

In the Democratic camp, more than a year before the 1939 primary, the newspapers reported that at the time of the spring 1939 shakeup at Democratic headquarters, the executive committee "unanimously went on record to keep out of the state races in the primary."21 The committee, however, endorsed the incumbent city and county elected

21 Joe Hart, "McLaughlin Resigns Post as Secretary," CourierJournal, April 22, 1939. 
officials. No action was taken in the local state representative or state senate races since they were considered state races.

It appeared from reports made a year after the 1939 primary election that McLaughlin and her followers, including her new mentor, County Judge Mark Beauchamp, had actively opposed gubernatorial

candidate Keen Johnson.

It is generally accepted by members of the party here from top to bottom that the fight is becoming a contest between supporters of John Young Brown and Lt. Governor Keen Johnson, who are seeking the Democratic nomination for Governor. Followers of Mrs. McLaugh1in to a great extent are partisans of $\mathrm{Mr}$. Brown and those in the other camp, favorable to Mr. Johnson. 22

In a newspaper editorial published a few months after the 1939 primary election, local factionalism was seen as the result of a previous statewide race.

Curious alignments and realignments have been occurring since the local democracy lost the leadership of "Mike" Brennan . . . Factions inevitably developed during the Barkley-Chandler contest a year and a half ago, and bad matters have been made worse by stupid handling. 23

Again, a newspaper reporter stated nearly a year after the 1939 primary

that the 1939 primary had produced local "fal1-out."

(County Judge Mark) Beauchamp would not be acceptable to the State forces because of his opposition in the primary to Gov. Keen Johnson and his support of John Young Brown. Nor would the fact that he has Mrs. Lennie $W$. McLaughlin in his political camp help him cause in Frankfort, for Mrs. McLaughlin was actively opposed to Governor Johnson. 24

22 Joe Hart, Courier-Journal, April 18, 1939. Johnson was Lt. Governor when A. B. "Happy" Chandler was Governor.

23 Editoria1, Courier-Journal, January 4, 1940.

${ }^{24}$ Joe Hart, "Scholtz Holds the Whip Hand to Organize Party," Courier-Journa1, November 13, 1940. 
McLaughlin had been in charge of the local Brown headquarters. Thomas A. Ballantine had been Brown's campaign manager.

The results of the 1939 primary produced some losses for McLaughlin's group. Keen Johnson, with $62 \%$ of the vote, beat John Young Brown, Sr. who gained $37 \%$ of the 68,646 votes cast. Cleveland gained $55 \%$ whereas his opponent May gained $26 \%$ of the 42,396 votes cast. Alderman Campbell won an impressive $75 \%$ of the vote, but it must be remembered that there was allegedly less of an interest in opposing incumbent city and county officials.

Johnson "cleaned up" in the City of Louisville precincts by gaining 35,987 votes compared to Brown's 19,592. But in the county outside the city limits, Johnson received 6,534 votes and Brown won 5,562 votes. Commissioner candidate May received in the county half again the number of city votes; his opponent Cleveland only picked up about 1,300 votes compared to May's approximately 22,000 city votes. It is obvious that the organization opposed to McLaughlin and her followers won the county in the 1939 primary election.

The November 7 general election resulted in Democrat Johnson carrying Jefferson County with $55 \%$ of the vote and a statewide defeat for Republican King Swope. William May was elected commissioner of agriculture, labor and statistics. In Jefferson County he defeated his Republican opponent, Van Alexander, by gaining 54\% of the votes cast. (Total votes cast in Jefferson County in the governor's race were 128,904 and in the commissioner's race, 122,807.) With 53\% of the 103,135 votes cast in the twelfth ward aldermanic race, Democrat B. J. Campbe11, Jr. beat his Republican challenger, Charles F. Franke.25

25 Democrats won all twelve aldermanic races and the city controllers race. Each received about 54,000 votes compared to each of 
1942

The August 2, 1942 primary was conducted against a background of World War II, and produced the lightest vote on record to that point in Kentucky history. There was a law prohibiting absentee ballots in the primary, so voters in the armed services and those who were working in the war effort away from home did not vote. "Secondary stubs will reappear at the bottom of the ballots, after an absence of six years? The voter had to detach the stub in the presence of election officials. In the session of the Kentucky General Assembly prior to the 1942 election, the Assembly restored this kind of voting procedure. A preprinted number on the bottom section of the ballot stub was different from the preprinted number on the top of the stub. The purpose was to prevent "chain balloting," meaning that "a crooked voter deposits a previously prepared ballot in the box and brings outside his own blank baliot to be marked and voted again by the next crook."27

The Democratic nomination for the United States senate seat was a hotly contested race in 1942. It pitted former Governor Albert B. "Happy" Chandler against John Young Brown, Sr. Brown had filed for the office only a few moments before the filing deadline on June $22 .^{28}$ A much less contested race was that for the United States congressional representative. Veteran incumbent Emmet $0^{\prime} \mathrm{Neal}$ was the favorite over two lesser known challengers, Chester E. Vaughn and John E. Daverin.

the Republicans receiving about 48,000 votes. There was significant straight party voting in the local races.

${ }^{26}$ Courier-Journal, August 1, 1942.

${ }^{27}$ Courier-Jounal, November 1, 1942.

${ }^{28}$ Courier-Journal, August $1,1942$. 
Backing Emmet $O^{\prime N e a l ~ w a s ~ a ~ s a f e ~ b e t ~ a n d ~ t h e ~ L o u i s v i l l e ~ D e m o c r a t i c ~ o r g a n-~}$ ization did so.29 (During this period, McLaughlin was not party secretary.) For the record, the organization's money was spent on behalf of O'Neal, but "the money being spent by the local Democratic organization actually will be used to help the candidacy of United States Senator A. B. "Happy" Chandler against John Young Brown."30. There was obviously more concern about Chandler's race.

Chandler had resigned as Governor on October 9, 1939 to be appointed by his former lieutenant governor and, by virtue of Chandler's resignation, Governor Keen Johnson, to the office of United States senator, a seat previously held by M. M. Logan. In 1940, Chandler ran for the unexpired senate term, an office he had wanted in 1938. In 1938, Chandler 1ost, however, in the senatorial primary to an incumbent, Alben Barkley.

In 1942 state level factions in the Democratic party were reflected at the local level in the election for the Democratic senatorial nomination. State Senator Earle Clements was John Young Brown's campaign chairman. Although there was no strong indication that Lennie McLaughlin's role in the primary was major, McLaughlin had long been associated with Clements and his faction.

Louisville Mayor Wilson Wyatt's role in the factionalism was not clear. The Democratic party county executive committee membership was mixed. A majority of them were holdovers from the former mayor (Joseph Scholtz) and his group. A minority of the members stemmed from

\footnotetext{
${ }^{29}$ Courier-Journal, August 2, 1942.

${ }^{30}$ Courier-Journal, August 1, 1942.
} 
the former Mayor Neville Miller's and McLaughlin's group. In December 1940, the chairman of the party was J. Donald Dinning who had replaced Blakey Helm, a follower of Scholtz. (Helm replaced Thomas F. Burke who had fallen from Scholtz's favor.) ${ }^{31}$ During this election of 1942 , John F. Dugan was the office manager of Democratic headquarters. In the 1920's Wilson Wyatt had been a part of a "close-knit group of young men interested in good politics and government" surrounding party leader General Percy Haley. 32 . Others among those young politicians were Neville Miller and Lennie McLaughlin. Wyatt's political roots tended to align him with the McLaughlin-Beauchamp faction during Wyatt's years, 1941 to 1945, as mayor of Louisville. In a later race for lieutenant governor running with gubernatorial candidate Bert Combs in 1959 , Wyatt was associated with the Barkley-Clements-Brennan-MillerMcLaughlin lineage, and not with that of the Chandler faction. 33

It appeared that Wyatt was in a complex situation in the 1942 primary. The 1940 Democratic party local reorganization elections of precinct committee members and representatives to the executive committee from each of the eight legislative districts had resulted in a comnittee

31 "City-County Democratic Shakeup Due," Courier-Journal, December 3, 1940. When Burke was retired from the post, some friends of McLaughlin on the County executive committee hoped that McLaughlin would return as a party official. That did not occur.

32 "Miss Lennie," Ken, November,1956, p. 7.

${ }^{33}$ Some persons did not put too much stock in the continuing factionalism between Chandler and the Barkley-Clements-McLaughlin wing of the Democratic party. A political observer wrote in 1956 that "a temporary rift in the Democratic party between Chandler and the Louisville and Jefferson County Democrats, not unlike the one that exists at this time, was settled in 1935 with a compromise worked out by Judge (Robert Worth) Bingham, Gen. (Percy) Haley, 'Mickey' Brennan and the late Dan Talbot, who was Chandler's close adviser." See, Ken, November, 1956, p. 8 . 
under the control of then Mayor Scholtz. "All this has the approval of the State administration and of the chief elements of the party in the county, outside the city limits."34 All matters of appeal in the party election process was to be submitted to the state central committee of the party, and people in the state capitol, Frankfort, approved the selection process prior to its actual occurrence. The central committee was dominated in 1940 by then-Governor Keen Johnson who was not supported by McLaughlin and her coterie. State Highway Commissioner J. Lyter Donaldson and his political advisor, Clifford E. Smith had their hands in the local reorganization, and they indicated a preference for Judge Loraine Mix as the favored mayoral candidate in 1941. Mix reported that he was not interested in the job.35 But when the 1941 mayoral primary came around, the local Democrats were spouting a unity theme for Wilson Wyatt and County Judge Mark Beauchamp. 36

Muddying the analysis of the 1942 election even more was the retrospective report that former Mayor Neville Miller had been sought by local party leaders to return to Louisville from Washington, D. C. to become chainnan of the local party executive committee. Miller reportedly said that any problem was with the Democrats in power. He claimed a lack of party leadership and the day-to-day operation of the party's activities was at fault. He preferred an operation similar to the old McLaughlin-Brennan days. "The strictly political groups, as typified by the Bandanna Club, feel that Wyatt is too far removed

${ }^{34}$ Courier-Journal, December 5, 1940

${ }^{35}$ Courier-Journa1, December 5, 1940.

${ }^{36}$ Courier-Journa1, October 2, 1941. 
from them and too close to such 'goody-good' government influences as the League of Women Voters and the Courier-Journal."37

What did all this mean for the senatorial contest between Chandler and Brown in 1942? Perhaps 1ittle, when one looks at the vote totals gained by the respective candidates. Chandler carried Jefferson County with $78 \%$ of the 28,527 votes cast. If Mclaughlin played a role in the primary, it was a defeat for her. Mclaughlin was fiscal court clerk at the time, and her role as an outsider in the party hierarchy may have salvaged her reputation in the defeat of Brown. But inasmuch as Chandler was the incumbent senator, a strong anti-Chandler effort by Wyatt and McLaughlin seemed far-fetched. It was possible there was a 1 ull in the factional storm in Jefferson County. 38

The organizational vote was light compared to the 1939 results. In 1942 the precinct by precinct vote was half that of the 1939 Johnson-Brown contest. The war obviously had an influence on the turnout. (The law set a $\$ 5,000$ limit on the amount of money to be used on election day. There were 628 precincts to be covered.)

The general election of November 3, 1942 provided a note for history. For the first time, twenty-five new voting machines were used in Jefferson County. Voters using these machines and the manual method elected Democrat Chandler over his opponent, Republican Richard

\footnotetext{
${ }^{37}$ Robert Riggs, "Neville Miller Is Reported Sought As Head of Democratic Party Here," Courier-Journal, April 4, 1944.

${ }^{38}$ Courier-Journa1, August 1, 1942. It was reported, however, that several city hall patronage people were not happy with "Happy" Chandler. As an aside, in 1942 the number of city and county civil service employees was 1,600, more than half of all city employees. Included in that number were police, fire, health, welfare and parks and recreation employees. They could do little more than vote.
} 
J. Colbert of Lexington. Chandler received $54 \%$ versus Colbert's $46 \%$ of the votes cast. Emmet $0^{\prime}$ Neal beat Republican Jouet Todd in the congressional race by gaining $55 \%$ versus Todd's $45 \%$ of the vote. Democrats must have been concerned over the lack of a large victory majority in the general election. It portended the eventual losses the Democrats suffered locally in the next few elections.

$\underline{1945}$

As the 1945 primary election approached, the cloud of the local Republican victory in 1943 was hanging over the Democratic party loyalists. No discussion of the 1945 election can begin without first noting the 1943 contests. The trend toward Republican victories was highlighted that year.

In 1943 , the Republicans swept the local races.

For the first time in ten years the Republicans carried Louisville and Jefferson County in every State, County and City race on the ballot, making a clean sweep of the twelve Aldermanic seats, the City controller's post, two County commissioners, all three State Senate seats and six of the eleven contests for State representative. ${ }^{39}$

For the first time since 1925, the aldermen and the mayor of Louisville were of different political parties. Wilson Wyatt was the Democratic mayor; his term ended in 1945. In 1943 a Republican governor, Simeon Willis, beat the Democrat, J. Lyter Donaldson of Carrolton, Kentucky. Willis defeated Donaldson in Jefferson County by about 3,500 votes.

The local news media stated there were several reasons for the Republican sweep in 1943. One was straight party voting. There were voters who disliked President Roosevelt's wage policies. Some called them too generous while others called them too strict and drastic.

${ }^{39}$ Courier-Journa1, November 5, 1943. 
During the campaign, Republicans tried to appeal to women and black voters. The news media suggested that more women appeared at political speeches than they did before the war. Many men, of course, were away from home during the war effort.40 On election morning, a front page news story told of a Republican handbill which cited that a Negro woman had been dragged from her home and beaten by two caucasian, Democratic police officers. The woman was then fined five dollars for disorderly conduct. 42 Whether or not such a handbill had an impact on either women or black voters was difficult to measure. But the fact remained that the traditionally Democratic stronghold, the area of the city north of Broadway called the "organizational district," did not counter the heavy turnout and the heavy Republican vote outside that organizational stronghold. 42

In 1945, McKay Reed was the new chairman of the local Democratic party. John F. Dugan was the organization chairman at local Democratic headquarters. Lennie McLaughlin was not a party official. She was clerk of the county fiscal court, having been reelected for a second, four-year term in 1944. She was concentrating on the effort to reelect County Judge Mark Beauchamp, who was completing his eighth year in that office.

In 1945, E. Leland Taylor was unopposed for the mayoral nomination in the Democratic party. (Taylor had been an unsuccessful candidate in the 1933 primary for that same office.) Incumbent Mark Beauchamp and Edwin Willis were opponents for the county judge nomination.

\footnotetext{
${ }^{40}$ Courier-Journal, November 2, 1943.

${ }^{41}$ Courier-Journal, November 3, 1943.

${ }^{42}$ Courier-Journal, November 4, 1943.
} 
Democratic headquarters warned its workers that an anti-organization ticket resembling the organization slate's printed material was being circulated. All the anti-organization candidates were running for countywide offices. "The County Judge (Beauchamp) denied having knowledge of circulation of Democratic slates on which his name had been inserted in place of Willis."43 Edwin Willis had received the endorsement of the Jefferson County Democratic executive committee, but five of the eleven members voted to endorse Beauchamp. Beauchamp accused some of the committee members of bolting the party and helping elect in the prior election the Republican Governor Simeon Willis. 44

Voters in the 575 city and county precincts produced a light vote on election day, August 4, 1945. Edwin Willis won the Democratic county judge race with $52 \%$ of the 25,358 votes cast. Mark Beauchamp gained $48 \%$. Beauchamp carried the county outside of the city by almost two-to-one. But Willis carried the city vote by more than 3,000 .

There were no contests in the Democratic primaries for county coroner, twelfth ward alderman and mayor. Dr. Vincent Stabile, Nolan Fallahay and Leland Taylor were the nominees for those respective offices. No primary contests were held in the aldermanic races for wards three, six, seven and ten. In the other eight wards, there were contests. Winners of those races received totals of between 10,000 and 12,000 votes, while the losers received less than 3,000 votes each.

\section{${ }^{43}$ Courier-Journal, August 4, 1945.}

${ }^{44}$ Courier-Journal, August 4, 1945. One group which did endorse Beauchamp was the advisory board of Roosevelt Colored Independent Voters League, through its spokesman and board chairman, Charles Scott. 
Lennie McLaughlin's political acumen is best expressed in the county judge race. In fact, she "fought with her back to the wal1."45 Results of the Beauchamp-Willis race were important both in terms of her reputation as an effective political organizer and her political future. "With Beauchamp as winner, Mrs. McLaughlin's political star would rise. She would have the distinction of defeating the regular organization, whose present setup is odorous (sic) to her."146

Although Beauchamp did not win the county judge nomination, he did receive a comparatively large vote against Willis.

\begin{abstract}
Bucking the regular political organization as an off-slate candidate is a tremendous job and one that rarely succeeds, but with "plenty of money" to spend, a fair amount of patronage to dispense and "Miss Lennie" to spend and dispense, Beauchamp seems to have done a surprisingly good job of bucking. 47
\end{abstract}

Beauchamp's votes came from the county outside the city limits and from the city regions of Portland and the West End. He was certainly helped in the west end by running with Circuit Clerk John Alsmiller, a popular candidate for renomination. Other prominent West End Democrats such as Jasper Hagan, Lawrence Wetherby, Lawrence Mackey, Martin Duffy and Ward Lehigh supported Beauchamp. But the "bottom line" appeared to be that Beauchamp worked very hard in the campaign, had money to spend, and depended on the managerial ability of McLaughlin.

Why did the Democratic organization not support a candidate such as incumbent Beauchamp? News reports indicated that the main reason was

${ }^{45}$ Thornton Conne11, "Win or Lose, Beauchamp Owes Credit For Remarkable Race to 'Miss Lennie'", Courier-Journal, August 7, 1945.

${ }^{46}$ Courier-Journal, August 7,1945 . Lennie McLaughlin was, of course, a patronage worker in the county offices. It was important that she win for her candidate for county judge.

${ }^{47}$ Courier-Journal, August 7, 1945. 
that Beauchamp, since 1944, had refused to contribute to the support and maintenance of party headquarters.

If he had paid the $\$ 300$ a month rent for headquarters

(then in the old Tyler Building), which one county commissioner said yesterday he had agreed to do, and if he had contributed the remainder of the two per cent of employees' salaries to the organization, it is considered likely that he would have been endorsed. 48

Instead, Beauchamp built up his own "war chest" with the patronage money and was able to spend lavishly on advertising and election day workers. The cost of the Beauchamp campaign was reported to have been $\$ 20,000$ to $\$ 30,000$. (Each of the three workers in the 576 precincts received $\$ 5$ for election day work. $)^{49}$ Another source of funds for the campaign was allegedly various owners of nightspots in the county outside the city limits. "If Beauchamp hasn't beat the organization, he has at least scared the socks off it." 50

In short, the tone of the 1945 primary was one of the Democrats girding themselves for the Republican opposition in the fall. Most Democratic races in the city had only one candidate each. Fear had been instilled in the Democratic party by the 1943 losses. The only substantial contest was that for the nomination of county judge. The real challenger to the organization was Beauchamp who had the strong support of McLaughlin. Even though Beauchamp lost the contest, McLaughlin would not lose her position as fiscal court clerk and a scant two years later she returned as secretary of the local Democratic

\footnotetext{
${ }^{48}$ Courier-Journal, August 7, 1945.

${ }^{49}$ Courier-Journal, August 7, 1945

${ }^{50}$ Courier-Journal, August 7, 1945.
} 
party. Her strong showing on behalf of Beauchamp no doubt enhanced her reputation in the world of local campaigns and elections. This election showed that over the long run it may be more important to play the political game aggressively.

The 1945 general election campaign had several issues. One was a proposed purchase by city government of the Louisville Gas \& Electric Company, the local utility. Republicans opposed the purchase, whereas the Democrats wanted to study the matter further. On another matter, Democrats were labeling the incumbent Republican Board of Aldermen "obstructionists."5I Democrat Leland Taylor stressed the accomplishments of the previous Democratic administrations of Miller, Scholtz and Wyatt. Republicans carped about the city's crime wave and the alleged poll fraud in the 1945 primary between Democrats Beauchamp and Willis. Leading Democrats, such as Mayor Wilson Wyatt, John M. Hennessey, chairman of the Democratic campaign committee, and Democratic organization chairman John F. Dugan, were predicting victory margins of 10,500 to 15,000 votes. On the other hand, Republican leaders, such as J. Ross Todd, chairman of that party, James G. Steward, Republican campaign committee chairman and Ed C. Block, Republican organization chairman, were predicting Republican victory margins of 5,200 to 7,500. None of them were on target in terms of majorities.

${ }^{51}$ Courier-Journal, November 4, 1956. The Courier-Journal editorialized that the same Republican Board of Aldermen was "strictly and pettily partisan," secretive, arbitrary and demagogic in nature during the 1945 budget process, compared to the 1944 budget process when the Board's president, Republican Judge Arthur Hopkins made the difference. See, editorial, Courier-Journal, November 4, 1956. 
Democrat Taylor beat Republican Roy W. Easley by only 221 votes of the 93,375 total cast in the mayor's race. 52 Democrat Nolan Fallahay lost the aldermanic race to Republican Linton H. Erdmann by 494 votes of the 90,846 cast in that race; Republican aldermanic candidates won. 53 Republican Horace M. Barker won the county judge's race, beating Democrat Willis by only 694 votes of the 111,322 cast. Three Republicans won the county commissioners' races to make a totally Republican county fiscal court. Republican Dr. Roy L. Carter beat the Democratic incumbent county coroner, Dr. Stabile. Carter's margin was only 422 of the 110,592 votes cast. Republicans won all but two of the remaining city and county races. Exceptions were Democrats Burrel H. Farnsley, who won a judgeship, and George C. Trager, county tax commissioner. Of the eleven state representative seats, Republicans won six and Democrats won five. Two Democrats won state senate seats. (Democrats controlled the state senate statewide, 21 to 17.$)^{54}$

The Jefferson County delegation to the state general assembly gave Democrats hope of a slow but sure Democratic comeback across the state after Republican Governor Simeon Willis' term expired in 1947. The balance of the Jefferson County political arena, however, looked bleak for the Democrats. The general feeling was that although Democrats still had control over the city chief executive position, losing the board of aldermen and the county courthouse hurt the

${ }^{52}$ This less than a landslide majority gave rise to the name of a group of Democrats who met on a regular basis and called themselves, the "221 Club."

${ }^{53}$ The first black alderman, Republican Eugene S. Clayton of the tenth ward, was elected at this time. See, Courier-Journal, November 11, 1945.

${ }^{54}$ Courier-Journa1, November 11, 1945. 
Democrats. But there was also the philosophy that "a Democratic Legislature is much more powerful against a Republican Governor than a Republican Board of Aldermen against a Democratic Mayor."55

A very substantial problem for the Democrats was their "lack of unified leadership . . Every official goes his own way unmindful of its effect on the party's fortunes, and often without conferring with those he leaves at the mercy of the Republican opposition."56 *

A retrospective look at the number of registered voters in various parts of Jefferson County in the period prior to the 1945 elections showed some changes in political demographics and the beginning of the lessening of city voters' strength in the voting booth. In the period 1937 to 1945 , the city lost $6.5 \%$ of its registered voters. The city had $4.5 \%$ fewer Democrats, $9.8 \%$ fewer Republicans and $3.4 \%$ fewer Independents. The county outside the city limits gained $19.2 \%$ more registered voters. In the county area, there was a $20.5 \%$ increase in registered Democrats, $14.1 \%$ gain in Republicans and a $31.4 \%$ gain in registered Independents. Overall, there was only a $2 \%$ decrease in the total number of registered voters in Jefferson County from 1937 to 1945.57

\section{$\underline{1948}$}

In January 1947, Lennie McLaughlin returned to the official party post of secretary to the Democratic party in Jefferson County. (It is ironic that this occurred while her old rival Leland Taylor was

${ }^{55}$ Courier-Journal, November 11, 1945.

${ }^{56}$ Courier-Journal, November $11,1945$.

${ }^{57}$ Figures used for this analysis were official registration totals as reported in the Louisville Times, October 27, 1937 and in the Courier-Journal, November 4, 1945. 
mayor of the City of Louisville.) McKay Reed continued as chairman of the Democratic executive committee, a position he had held since 1944. John Crimmins began in 1947 his duties as organizational chaiman of the Democratic party. The trio of "Lennie, Johnnie and McKay" continued for many years as the official party leadership.

The new combination of McLaughlin and Crimmins was not without opposition, however, in the 1947 primary. There were two slates of candidates. The McLaughlin-Crimmins team was headed by gubernatorial candidate Earle Clements. The opposing slate, organized by A. J. Bartholomew, Ray Stephenson and Philip Ardery was headed by gubernatorial candidate Harry Lee Waterfield. The lieutenant governor candidate, Lawrence Wetherby was backed by both McLaughlin and those supporting Waterfie1d. McLaughlin and Crimmins carried Jefferson County for their entire slate of state, county and city officials. 58 And happily for McLaughlin, Earle Clements and Lawrence Wetherby won statewide as well. Thus, McLaughlin would have influence with the Commonwealth's chief elected official. Such a situation never hurts a local party leader. Nineteen and forty-eight was a presidential election year with elections for a United States senator, third congressional district representative, local offices such as county coroner and an unusual election for the unexpired mayoral term of Leland Taylor who had died in 1948.59 The 1948 primary election provided what was called a

${ }^{58}$ In 1947, the Louisville Democrats regained the twelve seats on the board of aldermen, the so-called "Dann Byck Board," after having primary contests in only wards three, eight and twelve.

${ }^{59}$ The board of aldermen elected Taylor's successor. The courts required an election for the unexpired term of mayor in 1948. A regular election for a new four-year term was held in 1949. See Chapter III of this study for further details. 
"stunning blow" for the Jefferson County Democratic party organization and foretold the rising influence of organized labor in 1ocal politics.60

Prior to the August 7, 1948 primary, Senator Alben Barkley was chosen Democratic vice-presidential candidate on the ticket headed by President Harry S. Truman. That left Barkley's senate seat open. 6 I The two major Democratic contenders for that seat were Virgil Chapman, a Bourbon County attorney who had served as sixth congressional district representative, and John Young Brown, Sr. of Lexington.

Virgil Chapman had the support of Governor Earle Clements, a nucleus of McLaughlin's political family. John Y. Brown, Sr. had the support of Harry Lee Waterfield, Clements' primary opponent in the 1947 gubernatorial contest. 62 Chapman won the race statewide, but lost Jefferson County to Brown. Brown gained $58 \%$ of the 21,717 votes cast in Jefferson County. Chapman received $35 \%$ of that total. Brown's win in the third congressional district (Jefferson County) was "the result of a united front on his behalf by organized labor. Labor's defeat of Chapman was the first time the Democratic organization ever lost a primary fight in this district. The organization, of course, was for Chapman. 63

${ }^{60}$ Courier-Journal, August 8, 1948.

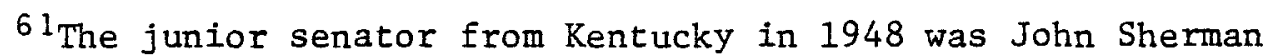
Cooper, Republican, who beat John Young Brown, Sr. for Chandler's remaining two years of his senate term. Chandler gave up that seat to become high commissioner of baseball. A Republican, Simeon Willis was Governor in 1946. Some Democrats never forgave "Happy" Chandler for what they felt was handing over the senate seat to Republicans.

${ }^{62}$ Courier-Journal, August 9, 1948.

${ }^{63}$ Courier-Journal, August 9, 1949. 
Even though only $22 \%$ of the county's registered Democrats voted in the primary, "Labor's victory definitely gains it prestige in politics in Jefferson County." 64 John Crimmins as spokesman for the Clements-McLaughlin wing of the party (the "organization" at the time), said that the organizational workers had been fooled by taking what appeared to be sure "Chapmanites" to the polls while obviously many of them voted for Brown. Brown's margin of victory over Chapman in the City of Louisville was about 4,000 votes.

In the third congressional district representative's race, Ralph H. Logan, son of the deceased United States Senator M. M. Logan, beat Vincent J. Hargadon. Hargadon won only $25 \%$ of the vote. Logan won the contest with the support of the McLaughlin organization with $75 \%$ of the 18,492 votes cast.

The 1948 primary for mayor of Louisville saw only incumbent Democrat Charles Farnsley in the race. The Republican primary had three candidates, but James G. Stewart won with $91 \%$ of the Republican votes. Some of Farnsley's backers, especially aldermen Leo F. Lucas and Nolan Fallahay and City Sanitation Director Joe Lannan, all influential in the west end precincts, demanded the ouster of McLaughlin as party secretary soon after the March 1948 selection of Farnsley as mayor by the board of aldermen. Farnsley either had not the power or the desire at the time prior to the Democratic primary to push for her ouster. (That came later in the December 1948 Democratic executive committee party races.) Lennie McLaughlin had promised not to legally challenge the board's selection of Farnsley. That and the desire of party leaders

${ }^{64}$ Courier-Journal, August 8,1948 . Labor activists in Jefferson County said they would oppose Chapman in the general election. 
such as Crimmins and Reed to cooperate with the newly elected mayor seemed to pave the way for an easy primary for Farnsley. 65

It appeared that the McLaughlin forces did not carry Jefferson County for their senatorial candidate, but did carry the county for the United States representative candidate. Perhaps the faction had some luck in not having a primary election for mayor and county coroner, a situation of an unexpired term being filled by an incumbent. And fortunately for the McLaughlin group, candidate Brown who carried the county in the senatorial race lost statewide.

The November 2, 1948 general election reflected that "Third Congressional District voters scratched like they had the seven-year itch."66 In the senate race, Republican John Sherman Cooper carried Jefferson County with $56.5 \%$ of the vote over Democrat Virgil Chapman. Voters totaled 140,147 in the race. But Chapman won the office statewide. In the race for third district congressman, Jefferson Countians chose Republican Thruston B. Morton of Glenview (a wealthy area outside Louisville) by giving him $53 \%$ of the vote over Democrat Ralph H. Logan of Anchorage (an equally wealthy area outside Louisville). Democrat Charles Farnsley won the unexpired term of mayor with $55 \%$ of the vote. Republican Dr. Paul S. Osborne filled the unexpired term of county coroner by a narrow margin of $50.1 \%$ of the 135,976 votes cast in that race.

The editorialists of the local newspapers called the 1948 general election the "most free-swinging election in history."67 And to top it

65 Thornton Connell, "Farnsley May Be Known as 'The Peacemaker,'" Courier-Journal, March 4, 1948. ${ }^{66}$ Courier-Journal, November 3, 1948. ${ }^{67}$ Courier-Journal, November $4,1948$. 
off, Harry Truman and Kentuckian Alben Barkley, the presidential and vice-presidential Democratic candidates, carried Jefferson County by only 1,111 votes. They defeated Republicans Thomas Dewey and Earl Warren in a race which produced 143,629 votes cast. 68

$\underline{1951}$

The August 4, 1951 primary election was a high-water mark for Lennie McLaughlin and her organization and a low-water mark for voter turnout. Offices of governor, commissioner of agriculture, labor and statistics and twelfth ward alderman, among other state and local offices, were open for contests. There was low interest and low voter turnout. Seventy-four per cent of the registered Democrats did not vote. Eighty-seven per cent of the registered Republicans did not vote. 69

Jefferson Countian and the previous lieutenant governor, Lawrence Wetherby, won the Democratic nomination in Jefferson County by gaining $89 \%$ of the vote. There was no substantial opposition in the Democratic party, and he won the statewide race as well. Wetherby was lieutenant governor under Governor Earle Clements. McLaughlin supported Wetherby.

There were no primaries for the commissioner's seat or that of twelfth ward alderman. There were contests for the aldermanic nominations in wards one, three, five and eleven. "All organization candidates of both parties, carried the county."70

${ }^{68}$ Strom Thurmond and Fielding L. Wright, candidates under the States Rights party banner, received 1.965 votes in Jefferson County. This was the largest number, other than candidates of the Democratic and Republican parties, out of the five party tickets on the ballot.

${ }^{69}$ Courier-Journal, August 5, 1951.

${ }^{70}$ Courier-Journal, August 5, 1951. 
The only antiorganization group in Jefferson County was that centered around the Democratic incumbent sheriff, Bernard J. Bax, a supporter of "Happy" Chandler. All Bax supported candidates were defeated in the primary. It appeared this factionalism only reared its head in the very local races and not those for state offices.

The fact was that this primary and those following 1951 did not have heated contests in the Democratic party. But the democrats had difficulty in general elections in Jefferson County. Republicans were winning some elections. There were growing numbers of suburbanites. The postwar young adults were not sure Democratic voters. This local situation was not unique as the national parties saw in 1952 and 1956.

There is no question, however, that 1951 was the beginning of a period when Lennie McLaughlin came into her own as the dominant leader of the Democratic Party in Jefferson County. She suffered few defeats until 1961 and 1964. Her problem was Republicans, not Democrats.

The general election of November 6, 1951 saw Lawrence Wetherby win Jefferson County with $54 \%$ of the vote over Republican Eugene Siler of Williamsburg, Wetherby won statewide. Commissioner of agriculture, labor and statistics Democratic candidate Ben S. Adams of Hopkinsville carried Jefferson County with $52 \%$ of the vote over Frank Irwin of Morganfield. Twelfth Ward Alderman Nolan Fallahay beat Republican John A. Lindeman with $52 \%$ of the vote.

All city and county offices were held by Democrats. Democrats recovered from Republicans three judgeships, the circuit clerk's office and the commonwealth attorney's office. A Democrat, Charles Farnsley, was still mayor in city hall, and a Democrat, Boman L. Shamburger had been elected county judge in 1949. Local Democrats were "on top of the political heap" in 1951. 
1954

The election of August 7, 1954 witnessed primaries in both the Republican and Democratic parties for a United States senate seat, but only a primary in the Republican party for the third congressional district representative. Democrat Harrison M. Robertson was unopposed in that race. The low interest in the election was reflected in newspaper reports that "although figures are not available, yesterday's primary may have broken all records for the small vote cast."7l Only 11\% of Jefferson County's 173,923 registered Democrats and Republicans voted. Former Vice President Alben Barkley ran for the Democratic United States senatorial nomination and won Jefferson County with $90 \%$ of the 13,448 votes cast. Republican John Sherman Cooper won the Republican nomination for that office by receiving $92 \%$ of the Jefferson County vote.

There is no question that Lennie McLaughlin supported Alben Barkley in the race. She had begun her political career with him in 1923 when Barkley ran for governor. Though unsuccessful in that effort, Barkley went on to become Kentucky's United States senator from 1927 to 1949 when he became the vice president. The Barkley-Clements-Wetherby faction of the Kentucky Democratic party was Lennie McLaughlin's true political home. It was not difficult for McLaughlin to carry the county for Barkley since he was very well known by the voters. Name recognition was no problem for Alben Barkley.

The belief that McLaughlin's problems were Republicans rather than Democrats during this period was reflected in the general election of November 2, 1954. Alben Barkley lost Jefferson County with only $49 \%$

\footnotetext{
${ }^{71}$ Courier-Journal, August 8, 1954.
} 
of the vote. Cooper received $51 \%$ of the 146,454 votes cast in that race. Some solace to McLaughlin must have been that her city portion of the county gave Barkley an almost 4,000 vote margin of victory there. The county ouside the city limits gave Cooper an almost 5,600 vote margin of victory. Republicans had predicted that Cooper would carry the county by 15,000 votes ${ }^{72}$ But the voters in the county outside the city limits began to make a difference in countywide races. Population increased in that county area, and many of those people voted Republican. McLaughlin was still able to carry the city precincts, but she had not the same loyal following in the county area.

As a final note, Republican John M. Robsion, Jr. won the third. district congressional seat, although by a slight $51 \%$ of the 143,573 votes cast in Jefferson County. Again, the Democratic candidate, Harrison M. Robertson won the city precincts by about 4,800 votes, but lost in the county outside the city limits by more than 5,000 votes. Robsion was the incumbent.

1957.

May 28, 1957 was the first primary election day which occurred in the spring rather than in the late summer. There were eighteen contests, including races for county judge, county coroner, mayor of Louisville and twelfth ward alderman. The "regular" Democratic organization led by McLaughlin, produced a stable of candidates and swamped all opposition in the primary.

Incumbent Democratic County Judge Bertram C. Van Arsdale had been appointed county judge in June of 1954 by then Governor Lawrence Wetherby. The newly elected county judge, George Wetherby, had been

${ }^{72}$ Courier-Journal, November 3, 1954. 
killed in an automobile accident. Van Arsdale went on to win the twoyear unexpired term in 1955. He was a candidate for a full, four-year term in 1957.

Van Arsdale had been Mayor Neville Miller's secretary in 1936 and 1937. He met and came to know such Democrats of that period as Judge Robert Worth Bingham, General Percy Haley, and Michael Brennan.73 Van Arsdale also had been secretary-examiner of the Louisville civil service board and a founder of the Jefferson County police merit system.

Van Arsdale's only opponent in the 1957 county judge's race was a perennial candidate, Jesse Cecil. The McLaughlin organization supported Van Arsdale.

There was neither a Republican nor a Democratic primary contest for the office of county coroner. There were no primaries in the Republican ranks for the offices of mayor, twelfth ward alderman and county judge.

In the Democratic primary for mayor of Louisville, the McLaughlin organization supported Bruce Hoblitzell and opposed Thomas James. The same organization also backed incumbent Twelfth Ward Alderman Nolan Fallahay against Roy R. Ohlson. The only other aldermanic contests were in wards three, ten and eleven.

There was a calm in local Democratic politics during this primary. This calm followed the storm that brewed the year or so before 1957. In 1956 there was a battle for control of local election machinery between supporters of then Governor "Happy" Chandler and those aligned

73 "Bert Van Arsdale," Ken, November, 1956, p. 13. 
with United States Senator Earle Clements and former Governor Wetherby. The 1956 Kentucky general assembly passed an election machinery law which made the secretary of state the ex-officio chairman of the state board of elections, allowed the govemor to appoint a Democrat and a Republican to complete the three-person board, and required appointment, by the state board, of county board of election commissioners in all one hundred and twenty counties in the Commonwealth. Previous state law provided that the county sheriff be the ex-officio chairman serving with two other members, one Democrat and one Republican. In 1956, the incumbent secretary of state was Thelma Stova11, a Chandlerite.

It would be particularly galling for Mrs. (Lennie) McLaughlin to see Mrs. Stovall as chairman of the state board that will appoint the Jefferson County board control of which means so much to the Jefferson County Democratic organization. 74

All precinct election officials and the issuance of challenger certificates would be under the control of such a new board. 75

The Democratic state convention of the summer of 1956 displayed bitter factionalism. At controversy was the pro-Chandler credentials committee's challenge of the seating of pro-Wetherby/C1ements/McLaughlin delegates and its recommendation that the pro-Chandler delegates from four Jefferson County legislative districts be seated. Although the disputed delegates only represented a minority of all delegates, McLaughlin led a walk-out protest from the convention and subsequently

${ }^{74}$ Courier-Journal, March 18, 1956.

${ }^{75}$ McLaughlin's political opposition to Chandler and Mrs. Stovall was exhibited in Stovall's vote returns from Jefferson County in the 1955 primary election for secretary of state. Stovall lost Jefferson County, although she was a resident of that county, to June L. Suter of Warsaw, Kentucky, who received McLaughlin's support. Stoval1, however, won the election statewide. 
lost her seat on the state Democratic executive committee. County commissioner, and former county judge, Mark Beauchamp also lost his position on the state committee. ${ }^{76}$

The Democratic party officials' election in December, 1956 threatened to pit Chandler candidates for legislative district committeemen and women against those supporting the McLaughlin group. But the effort of former County Sheriff Bernard Bax and attorney Robert Hatton to lead the pro-Chandler forces in an attempt to control the party failed. The pro-Chandler forces were unable to obtain a sufficient number of seats on the county executive committee. A majority of those elected in the winter party elections were supporters of McLaugh1in. 77

And so in 1957, the local Democratic party organization was firmly under the control of Lennie McLaughlin and her partisans. The primary of that year showed her strength. Van Arsdale won the county judge nomination with $94 \%$ of the 32,798 votes cast. Bruce Hoblitzell swept the city precincts to receive $89 \%$ of the 24,173 votes cast for the mayoral nomination. Nolan Fallahay won the twelfth ward aldermanic nomination with $88 \%$ of the 19,170 votes cast. Fallahay polled the largest number of votes in any of the aldermanic races. But in the four contested aldermanic races, the winners received at least a 1,500 vote margin. Twenty-five per cent of the 131,587 city and county Democrats registered at the time of the primary voted.

The November 5 general election resulted in a Democratic Hoblitzel1 victory over Republican Robert B. Diehl with Hoblitzel1

\footnotetext{
${ }^{76}$ See, Don Freeman, "'What A Farce!' Those Leaving Shout; Mrs. McLaughlin Says 'We Won Fairly'", Courier-Journa1, July 4, 1956.

${ }^{77}$ See, Courier-Journal, November 29, 1956 and December 9, 1956.
} 
receiving $54.5 \%$ of the 105,404 votes. Alderman Fallahay gained $54 \%$ of the 104,295 votes cast to defeat Republican Harold E. Alwes. All Democratic margins of victory in the aldermanic races were of the same general percentage as Fallahay's. County Judge Van Arsdale was reelected over Republican challenger, Charles E. Gaines by gaining $52 \%$ of the 149,955 votes cast. He lost the county outside the city limits by about 2,000 votes. Democrat Dr. George F. Dwyer beat Republican Dr. Paul S. Osborne for the job of county coroner with $52 \%$ of the 147,302 votes cast in that race.

The total of registered Republicans and Democrats in Jefferson County at the time of the general election was 226,819 . In the city $68 \%$ of them voted in the mayor's race. Republican mayoral candidate Dieh1 only carried the first ward of the city, and lost in wards five, eight, nine and ten by only a few hundred votes each.

In other races, former county judge and incumbent County Commissioner Mark Beauchamp won his third term as commissioner. (Other county commissioners were Robert Fihe and Mortimer Viser.) Only one Republican in Jefferson County won a seat in the state house of representatives in 1957, Marlow Cook of the 34th legislative district. The 38th state senatorial district race did give Governor Chandler a small victory of sorts. Democratic organizational legal counsel, Arthur Grafton, who had opposed Chandler in the previous general assembly, lost his seat to Scott Miller, Jr.

All in all, the 1955 to 1957 period of local politics was a high spot for Lennie McLaughlin and her organization. She was winning primary and party elections and she was also beating Republicans in the general elections. The late 1950's were McLaughlin's dominant days. Those days were numbered. 
$\underline{1960}$

Demographics of Louisville and Jefferson County in 1960 provided some surprises for local community leaders and political persons. These demographics impacted upon the political scene. Preliminary figures of the 1960 census revealed Jefferson County's population to be 605,113 , a figure 8,487 less than what the local Chamber of Comnerce had estimated. Since 1950, the City of Louisville population had increased $4.5 \%$ to a 1960 total of 385,688 . In 1960 , the population of Jefferson County outside the Louisville city 1imits was 219,425 , a $95 \%$ increase over the 1950 figure. The future offered strictly county residents increasing influence in countywide elections.

In 1960 , state politics were dominated by the Democratic administration of Governor Bert Combs who had defeated Chandler-backed candidate, Lieutenant Governor Harry Lee Waterfield for the party's nomination in 1959. Through voter registration and election day efforts, the local McLaughlin organization helped turn out part of the 75,000 voters in that primary, "the greatest number in history for a primary election."78 Organization chairman, John Crimmins guessed that more than 15,000 persons came out to vote because of the organization's efforts. Waterfield backer, Leo Lucas, admitted that all the money and organization possible could not have turned around the anti-Chandler feelings in the urban areas. Thus, Lennie McLaughlin was an important political leader for Governor Combs in Louisville and Jefferson County. There were few primary contests on the May 24 th election day. Republican United States Senator John Sherman Cooper had token opposition

\footnotetext{
${ }^{78}$ Richard Harwood, "Over 5,000 Party Organization Workers Helped Combs Pile Up 29,000 Majority Here," Louisville Times, June 2, 1959.
} 
in the primary from Thurman Jerome Hamlin of London. Cooper won the primary. (The other United States Senator from Kentucky was Republican Thruston B. Morton, having been elected in 1956.) Cooper ran for a full term in the fall of 1960, but had filled the unexpired term of Senator Alben Barkley who died in 1956.

Democrats in the senatorial primary numbered five, but two were the popular vote-getters, Keen Johnson, the former governor, and John Y. Brown, Sr. of Lexington. The McLaughlin organization backed Johnson. There was no Democratic primary for third district congressman. Frank W. Burke was unopposed. Although 1960 was a presidential election year, there was no presidential preference primary in this period of Kentucky history.

Keen Johnson of Richmond won the primary with $55.4 \%$ of the 28,579 votes cast in Jefferson County. Brown gained only 285 more votes than Johnson in the county outside the city limits. Johnson won the city precincts by almost 5,000 votes. McLaughlin and Crimmins reasoned that the local vote for Brown, who had no precinct organization, must have been a protest vote against the state sales tax, especially perceived as a tax on food in the heavily Democratic Louisville neighborhoods of Portland and Germantown. 79

McLaughlin was still able to carry the city precincts for the candidate of her choice, but the county precincts outside the city limits continued to slip from her grasp. This pattern is not unusual for city political leaders once the population swell of the suburban voters becomes a viable force.

The November 8 general election resulted in the city voters and those outside the city limits electing Republican John Sherman Cooper.

${ }^{79}$ Courier-Journal, May 25, 1960. 
Cooper received $59.5 \%$ of the 231,818 votes and defeated Democrat Johnson. Cooper's victory margin in the city precincts was a little more than 16,000 votes and in the county outside the city limits, 28,000 votes. Third district congressional candidate Democrat Frank Burke beat Republican Henry R. Heyburn with $50.2 \%$ of the vote. Burke received only 1,158 more votes than Heyburn. Total votes cast in that race were 229,684 .

In the presidential and vice presidential race, McLaughlin helped produce a lead of 9,796 votes for John F. Kennedy and Lyndon B. Johnson in the city precincts. In the county outside the city limits, however, the Republican ticket of Richard Nixon and Henry Cabot Lodge led with 11,191 votes. After the city and county votes were totaled, 235,755 votes were cast in the race. The Republican ticket carried the entire county with a lead of 1,395 .

1963

Between the 1960 election and the May 28, 1963 primary, there were several political events which were important to the political future of Lennie McLaughlin. Certainly not the least of these events was the Republican sweep of local elective offices in 1961. Another important factor was the growing alliance between Democratic Governor Edward T. "Ned" Breathitt and local Democrats who were organizing to take over leadership of the local party from McLaughlin. McLaughlin's political patronage resources were severely limited by the Republican victories in 1961. Republican Marlow Cook won the county judge's office with $56 \%$ of the vote. Republican William Cowger became Louisville's mayor with $55 \%$ of the vote. All twelve aldermen were Republicans. One county commissioner was a 
Republican, and two were Democrats. The city controller was a Democrat. McLaughlin was able to help some applicants for federal jobs because of her connections with the national Democratic administration. But even with her contacts with state government, there is no doubt that the lack of local patronage hurt her political power base. Contributions to Democratic headquarters were negatively effected since the traditional two per cent contribution from patronage paychecks were not forthcoming from city hall or the county courthouse. On top of that, the people who had been part of that patronage base for so many years were growing older.

By 1963, both United States senators from Kentucky were Republican. In 1962, Democrat and former Mayor Wilson Wyatt had lost the senate race to Republican incumbent, Thruston B. Morton. Republican John Sherman Cooper was in the midst of his first, full six-year term. Furthermore, in 1962 Democrat Frank Burke lost his third district congressional seat to Republican M. G. "Gene" Snyder.

The 1963 primary had races for governor, lieutenant governor, commissioner of agriculture (labor and statistics had been dropped from the title), county commissioners, aldermen and other state and local offices. Democrats running for the gubernatorial nomination were Edward T. (Ned) Breathitt of Hopkinsville, Albert B. "Happy" Chandler, Mary Louise Foust of Shelbyville, and Wilton Benge Cupp of Covington. Candidates for the lieutenant governor's nomination included Harry Lee Waterfield and John B. Breckinridge. Candidates for the commissioner of agriculture were Thomas 0 . (Tam) Harris, Price Holbrook, Jr. Wendell Butler and A. R. (Ray) Dyer.

There was some slating by both the Chandler and the Breathitt forces. In Jefferson County the Breathitt slate included Wendell Butler. 
Breathitt said that either Waterfield or Breckinridge was acceptable to him. 80 Waterfield had been identified earlier with Chandler, and a popular slogan of the campaign was "A. B. C. and Harry Lee in '63." Chandler's slate included Tom Harris and had the support of the local United Auto Workers, led by Owen Hammond, and the Independent Teamsters union. The leadership of the AFL-CIO state executive board, however, supported Breathitt. Labor leader, Sam Ezelle, a previous Chandler support, backed Breathitt. 81

Two days before the primary, news reports stated:

The regular Democratic organization here (in Louisville) kept a factional fight out of the local primary by taking the unprecedented action of taking no part as an organization for any candidate in the govemor's contest. The local slate endorsed by Democratic organization in, in effect, a coalition ticket of candidates who individually support one of the contenders in the top spot primary. 82

But news reports in mid-1964, with clearer hindsight, indicated that "in a last minute move Mrs. McLaughlin lined up many of her precinct workers for Breathitt. She made sure they put Breathitt's name in the blank space on the organization's slate, the day before the election."83 The local group supporting Breathitt, led by attorney 01dham Clark,

${ }^{80}$ Courier-Journal, May 26, 1963.

${ }^{81}$ Chandler supported James Queenan for the office of clerk of the court of appeals. Queenan was considered an antiorganization candidate. He was unsuccessful both in that race and in the later race for the Democratic mayoral nomination in 1961.

- 82 Courier-Journal, May 26, 1963.

8 Ivan Swift, "Blume Bloc Driving To Oust Miss Lennie," Louisville Times, June 11, 1964. 
was upset by the early neutral attitude of party headquarters during the Breathitt-Chandler 1963 campaign. 84

In the 1963 primaries for alderman, the organization under McLaughlin endorsed Dr. Charles Riggs in the twelfth ward along with W. Goebel "Tubby" Sanders in the third, Joseph Edward Mobley in the fourth, Raymond (Pete) Korphage in the fifth, Richard Beliles in the seventh and Clifford $\mathrm{J}$. Haury in the eleventh. McLaughlin also endorsed Bud Veith, veteran city controller.

When the votes were counted, Breathitt had beaten Chandler countywide, with $59.4 \%$ of the 81,990 votes cast. Breathitt also won statewide. In the race for the nomination as 1ieutenant governor, Breckenridge lost to Waterfield in the city precincts by only 297 votes. Breckenridge won in the county outside the city limits, and won the county as a whole with $51.8 \%$ of the 55,180 votes cast. Waterfield, however, won statewide. Wendell Butler carried Jefferson County in the commissioner's race with $55.1 \%$ of the 25,284 votes cast. His nearest competitor was Tom Harris who gained $24.9 \%$ of the total. Dr. Charles Riggs won the twelfth ward aldermanic nomination with $67.4 \%$ of the 13,083 votes cast. 85 McLaughlin's candidates, Butler and Riggs provided a victory for her. Breathitt's win was only half a victory since there was some question about the depth and breadth of McLaugh1in's support for him.

${ }^{84}$ During. this time, Raymond Bossmeyer was the new party chairman, having been selected in 1962. Bossmeyer was twelfth ward alderman and a McLaughlin partisan.

${ }^{85}$ The official vote totals show that former Alderman Nolan Fallahay received 20 votes, an obvious write-in effort. 
The general election of November 5, 1963 resulted in Breathitt's losing Jefferson County to Republican Louie B. Nunn of Glasgow. Nunn received 4,134 more votes out of a total of 184,848 votes cast in that race. Breathitt, however, won statewide and became governor. Although Harry Lee Waterfield won statewide, he lost in Jefferson County to Republican H. Bemis Lawrence of Louisville. Lawrence won by 6,496 of a total 181,702 votes cast. Republican Hugh James of Lexington won the commissioner's race in Jefferson County by receiving 9,050 more votes of a 176,690 total than Democrat Butler. Breathitt, Butler and Waterfield all won in the city precincts, but lost in the county precincts outside the city limits.

In the aldermanic races, Dr. Riggs lost by 799 votes of a 109,300 total to Republican Oscar G. Stall. Republicans won in the other eleven aldermanic races, but all by rather slim leads. The only Republican victor was Eleventh Ward Alderman Louise Reynolds who won by more than 1,000 votes. Democratic City Controller Bernard "Bud" Veith did beat Republican Roland Whitney, but by only 126 votes. 86

For the first time in sixteen years, the county fiscal court was totally Republican. Democrats Thomas Ballantine and Robert "Doc" Fihe lost their county commissioners' races to Republicans John E. Skelton and Maurice W. Archer. The vote results showed the Democratic losses were because of heavy Republican voting in the county precincts outside the city limits. 87

${ }^{86}$ In 1963 in the 43rd legislative district race, Norbert Blume beat Republican John A. Lindeman, 5,146 to 3,913. Blume was part of the anti-McLaughlin faction of the Democratic party.

${ }^{87}$ In 1963 , ten of the seventeen state house seats from Jefferson County were held by Republicans. One of four state senate seats from Jefferson County was held by a Republican. See, Courier-Journal, November 6, 1963. 
A 1963 update of the numbers of registered partisans in Jefferson County and a comparison to the 1937 and 1945 figures showed scant change in the pattern of Democratic registration. In 1963 there were 139,920 registered Democrats in Jefferson County. There had been 99,814 registered Democrats in the county in 1945 and in $1937,99,511$. On the other hand, 1963 registered Republicans in the county numbered 84,066. In 1945 registered Republicans numbered 57,670 and in 1937 , 61,568 .

From 1937 to 1963, the total number of both registered Democrats and Republicans increased by $39 \%$. Registered Democrats increased by $40 \%$, as registered Republicans increased by $36 \%$. In 1963, registered Democrats were $62 \%$ of party affiliated voters in Jefferson County. In 1937 , Democrats had been $61 \%$ of the party affiliated registrants. Proportionally, a twenty-five year period saw slight change in the registered strength of the Democrats.

Even though there was little percentage increase of either Democratic or Republican registered voters over the years, the population increase in the county outside the city limits and the heavier concentration of Republicans in those county precincts, made the situation difficult for the head of the city Democratic organization. McLaughlin might be able to carry her candidates for citywide offices or win the city precincts for those county and statewide office candidates, but it was becoming increasingly difficult for her to assure her candidates victory in the county precincts outside the city limits. In a sense, the voters in those county precincts were determining the political future of the urban political boss. 
Primary Election Analysis

Earlier, this investigator expressed the hypothesis that a party organization "boss," to maintain control over the organization, must be able to produce in a primary election the votes necessary for the boss' candidate to win the election. The boss is then able to control the party nomination process. Thus, a criterion of a party machine is met.

Over the years, were Lennie McLaughlin and her organization able to control the nomination process in Louisville to the extent their candidates were chosen to be the Democratic party's nominees? Let us analyze the election results from that thirty-year period and note Mrs. McLaughlin's results at the voting polls.

The period 1933 to 1963 coincided with Lennie McLaughlin's years of activity in the local Democratic party. Every third year, after the first year of 1933, was chosen. Particular primary races were consistently chosen if these races were on the ballot. The races were selected because of the position on the ballot. Thus, the factor of voter roll-off from the more visible and first-listed races at the beginning of the ballot to those less visible races listed toward the end of the ballot was taken into consideration. Moreover, the races reflected citywide and countywide elections.

The following races' vote totals were used, if they appeared on the ballot that particular year:

United States Senator

United States Congressman, Third District

Kentucky Governor

Kentucky Commissioner of Agriculture, Labor and Statistics Jefferson County Judge 
Jefferson County Coroner

Louisville Mayor

Louisville Twelfth Ward Alderman

in total, thirty-three races analyzed.

News articles and interviews with contemporary political party activists were used to determine which primary candidates in those particular races were supported by Lennie McLaughlin and her organization. If there was no primary opposition, the results are noted as "no contest." Lack of primary opposition can often mean that challengers avoid running against a candidate who exhibits strong support from the party organization. So the number of "no contests" does not necessarily mean McLaughlin was not influential in the primary races. McLaughlin was active in the Democratic party during the time when the policy of the Louisville party was that of a "closed primary." That is to say, the party hierarchy frequently made the choices of who would be the preferred primary candidate. All of these races occurred before the so-called "new politics" of heated primaries with much media exposure and large sums of dollars spent to woo the voters, often without the aid of party grass roots organization and its precinct officials. There were contests when personality-centered factions were vying for the prize, but most of these occurred prior to 1948 .

Appendix I reflects the raw numbers of primary elections won and lost by McLaughlin. Too, it lists the number of elections in which there were no contests. The totals are further subdivided into three time periods: 1) 1933 to 1936, McLaughlin held the official party post of party secretary, but Michael Brennan was still the "boss" of the Louisville Democratic organization; 2) 1939 to 1945 , McLaughlin 
was not the party secretary; and 3) 1948 to 1963, McLaughlin was again party secretary (See, Appendix II, III).

Over the entire period, 1933 to 1963, McLaughlin won fifteen of the thirty-three elections, $46 \%$ of the total. There were no contests in ten of the thirty-three races, $30 \%$ of the total. McLauginlin lost eight of the thirty-three races, $24 \%$ of the total.

But, if one analyzes the time 1948 to 1963, the results are substantially different. McLaughlin won ten of the fifteen total wins throughout this time. Sixty-seven per cent of her wins were from 1948 on. Seven of ten races, or $70 \%$ of all no contests were in this span of time. And only one of eight losses, $13 \%$ of all losses, were during 1948 to 1963.

McLaughlin's heaviest losses were in the period 1939 to 1945 . Of all her losses, $63 \%$ occurred then.

The higher number of noncontested races in the 1948 to 1963 period combined with the number of races won by McLaughlin led to the conclusion that McLaughlin and her organization were able to carry the vote for the candidates they supported in primary elections. The obvious conclusion is that from 1948 until her retirement in 1965 , Lennie McLaughlin was the boss of the Democratic machine in Louisville, Kentucky. 
CHAPTER V

CONCLUSION

Lennie McLaughlin was unique as a party leader of Louisville's Democratic Party because she was a woman. She fulfilled the tradition of a political "boss," however, because she used the same methods other political leaders used to maintain and control the organization, or "machine." McLaughlin utilized the organization's grass-roots, precinct workers and the county executive committee to determine the victors in party primary elections. As long as the leader was successful in supporting the candidates who were winners in the primary, that leader's political turf was relatively secure.

McLaughlin maintained control over political patronage in Louisville. As a general rule, local Democratic headquarters reviewed applicants for jobs in agencies and departments run by Democratic elected officials. McLaughlin is remembered by many of her contemporaries as being fair in her role as patronage chief. She informed the prospective job-holder that a word from Democratic headquarters might help the applicant obtain the job, but performance on the job was the criteria for keeping the job.1 In return for the applicant's receiving employment, the employee was expected to contribute financially on a regular basis for the upkeep of Democratic headquarters.

\footnotetext{
'McLaughlin's contemporaries have told this investigator that McLaughlin sent well-qualified applicants for job interviews. One such contemporary characterized Democratic headquarters as "one of the best employment agencies in town in those days."
} 
McLaughlin's patronage influence extended beyond a Democratic controlled city hall or county courthouse. Because of her contacts with Democratic state and national elected officials, her organization enjoyed the benefits of patronage on those levels of government. Those Democratic elected officials in tum depended upon the resources of the local Democratic party's precinct organization. Lennie McLaughlin enjoyed political relationships with the members of the local delegation to the Kentucky general assembly. She had great influence over whether or not legislation was introduced to the assembly by a member of the Jefferson County group. During the legislative session, she and other leaders of the local Democratic organization met with the delegation on a weekly basis. Local government leaders were often a part of this caucus. Discussions about the impact of legislation on Louisville and Jefferson County and the unified stand to be taken on votes were common. During the session, the meetings were held in Frankfort, the state capitol. At other times, sessions were conducted at Louisville's Democratic headquarters. Pressure on the legislators to go along with the McLaughlin organization was subtle, most of the time. Locally elected legislators did not have to be reminded that the organization influenced the nomination and election of legislators. Contemporaries of Lennie McLaughlin agree that her strong suit was that of precinct organization. From the beginning of her association with the local Democratic party, McLaughlin conscientiously maintained lists of names of individuals who represented the party as precinct captains or group leaders. She was a walking library of information about these individuals and their performances in the electoral process. She knew them well. McLaughlin trained in the art of precinct organization under her mentor, Michael "Mickey" Brennan. 
Brennan died at the age of 61 in 1938 . It could be concluded that his death startled the local Democratic organization. The illness preceding his death was unexpected. The fact that Brennan was on holiday in Arkansas prior to the illness which caused his death, reinforces the theory that neither he nor his associates in the party anticipated Brennan's death. If Brennan had suffered a lingering illness, it is likely that there would have been more of a struggle in making the decision of who would be the heir to his leadership. McLaughlin filled in as leader of the organization. She had assisted Brennan for several years and understood the workings of the organization. At a time when the organization needed to be held together, it was not important that Mclaughlin was a woman. It is true that within one year after Brennan's death, Mayor Scholtz and his supporters in the party ousted McLaughlin from her position as party secretary. That ouster had little to do with McLaughlin being a woman. It had to do with the fact that Scholtz headed a rival faction which wanted control of the organization. If Scholtz could not trust McLaughlin, who had the knowledge and experience in running the party, he needed to oust her.

The need for a coalition of leadership gleaned from all factions of the party resulted in McLaughlin's being reinstated as party secretary in 1947 . It mattered not that she was a woman. What mattered was that she was a strong-willed, experienced party worker. Her expertise was needed at a time subsequent to the local Republican victories of 1943 and 1945. Her determination to make the local Democratic party successful was evident. 
It is noted that the organization McLaughlin headed during the $1950^{\prime}$ 's had a substantial number of female precinct captains. Of the 457 captains in the Democratic party, 152 (33\%) were women in 1957. The local Republican party had an even higher percentage of women workers in, that year. Republican semale captains totaled 229 (50\%).2 The trend toward female precinct captains was obvious during the Second World War when many of the male captains were away from Louisville in the war effort.

There are general observations regarding Louisville's Democratic organization which are pertinent to an analysis of its operation. Although present day Louisvillians currently active in the Democratic party often stereotype the party of the past as one of control and unity, the reality is that there were competitive primary contests over the years. There were factions within the local Democratic party. These factions supported different candidates in the party primaries. Many of these primaries resulted in narrow margins of victory. The Democratic primaries of 1933, the Unites States senate primary of 1936 , the elections of 1945 and the Democratic mayoral primary of 1961 are examples of competitive primaries. Perhaps, present day Democrats remember the primary elections of the $1950^{\prime} \mathrm{s}$ as a basis for the stereotype. Certainly those primary elections offered little competition. There were, however, factional disputes through the years.

This study indicates that the factionalism within the local Democratic party is directly related to the factionalism on the state level. Local factions consistently centered on supporters of statewide Democratic candidates or elected officials. McLaughlin's tradition was

\footnotetext{
${ }^{2}$ Courier-Journal, November 2, 1957.
} 
associated with the branch of state Democratic politics personified by Ruby Laffoon, Thomas Rhea, Alben Barkley, Earle Clements, Lawrence Wetherby and Bert Combs. The other main Louisville faction was centered on Albert B. "Happy" Chandler, Harry Lee Waterfield, and, at one time or another, Keen Johnson and John Y. Brown, Sr. The roots of factionalism in Louisville were firmly grounded in state politics. Hybrid flowers representing local personalities and political ambitions with few obvious connections to the root system appeared in primary contests. But the network of political associations and connections between and among Louisville Democrats were more often than not a direct result of state factionalism.

During the period of this study, Louisville's black population was not represented in the major leadership of the local Democratic party. Louisville black citizens did not change political allegiance from the Republican party to the Democratic party as quickly as did blacks in other locales.

An early example of black dissatisfaction with the local Republican party occurred in 1921 after the passage of a discriminatory housing ordinance by a Republican administration. The result of this dissatisfaction was the formation of an independent Lincoln party of blacks who attempted to elect blacks to city and state offices. Their efforts were unsuccessful.

There were instances when blacks became involved with the local Democratic party. Republican Eubanks Tucker unsuccessfully ran for a state legislative office with the support of some local Democrats in 1935. Mayor Neville Miller's administration provided a few middle management jobs for blacks. In 1945 both Republicans and Democrats had black 
candidates for aldermanic offices. Republican Eugene Clayton won his tenth ward race, but William Beckett did not win in the eighth ward. Clayton was the first black elected to the Louisville board of aldermen. Clayton's vote total was similar to white Republican candidates who won the other eleven seats on the board.

Democrat William Beckett was elected eighth ward alderman in 1951 and served until 1961. His was the sole vote for the adoption of an antidiscriminatory, public accommodations ordinance in 1960. Beckett was unopposed, however, in the 1961 Democratic primary. He lost the office along with all other Democratic candidates for the board as a result of the Republican sweep in the 1961 general election. Both Clayton's and Beckett's elections revealed that in the days of straight party voting in a citywide race, it was beneficial for blacks to be a part of a party ticket. ${ }^{3}$

Depending on the nature of the election and the anticipation of a close contest, local parties might court the black voters. Local Democrats courted blacks in 1944 on behalf of President Franklin D. Roosevelt. But Republican Thomas Dewey received $52 \%$ of the vote in the precincts with a substantial number of blacks. ${ }^{4}$ Roosevelt, however, received a larger percentage of the black vote than did the Democratic gubernatorial candidate J. Lyter Donaldson. In 1948, Louisville Democrats made a bid for the black vote for Harry Truman. But local Republicans, such as Charles Anderson, publicized black prizefighter Joe Louis' endorsement of Thomas Dewey. Republican Dewey won the black precincts with $63 \%$ of the vote.

${ }^{3}$ Ernest Collins, "The Political Behavior of the Negroes in Cincinnati, Ohio and Louisville,Kentucky." Ph.D. Dissertation. (Lexington: University of Kentucky, 1950), pp. 163-165.

${ }^{4}$ Collins, p. 92 . 
There was a general feeling among many of the Negro leaders

in Louisville that the local Democratic Party had not been

as generous as the Republican Party in recognizing and

rewarding them for their support. 5

Lack of support of the local Democratic party by blacks continued into the 1960 's.

Civil rights were issues in the city and county elections of

1961. Both parties hoped to obtain the votes of blacks. But the Republican campaign appeared to have been more successful in the effort. Republicans gained solid victories in the white eastern precincts of the City of Louisville. Democrats were unable to hold on to any margin in the black precincts. Wards in the midwestern part of the city where many of the black citizens lived at that time were won by the Repub1icans.

There were other reasons for blacks to be attracted to the local Republican party. Beside the fact that Republicans had been more generous with patronage jobs for Blacks, there was more black representation on the Republican city-county:executive committee than on the Democratic county executive committee. In 1948 five blacks were on the Republican committee. The local Democratic party refused to support a black for membership on their county executive comittee in $1948 .{ }^{6}$

The difficulty faced by the Democratic Party in Louisville in its relation to the Negro voters is that of reconciling the viewpoint of the 'lily white' faction of the party with the view of the faction which advocates acceptance of the Negroes as political equals. 7

The first black members of the Democratic committee were State Representative J. E. Smith from the 42nd legislative district and Mrs.

${ }^{5}$ Collins, p. 100 .

${ }^{6}$ Louisville Defender, December 11, 1948.

${ }^{7}$ Collins, p. 202. 
Georgia Davis from the 40th legislative district who were both elected in 1964. (Georgia Davis Powers later was elected state senator.) These elections occurred during a quadrennial reorganization of the local Democratic party which reflected efforts to change local party leadership in a period of social change in the local community.

The obvious conclusion is that, for the most part, Louisville blacks were not a part of Democratic party leadership, were not consistently supporters of Democrats in elections and were not courted on a regular basis by the Democratic party. These patterns changed, however, toward the latter years of the 1960 's and the years following.

This study draws further conclusions based upon an analysis of Louisville and Jefferson County demographics and voting behavior from 1933 to 1977. Areas included are: 1) voter turnout for general elections; 2) the roll-off rate and percentage of total vote in those same elections; and 3) population and voter registration data. Elections for the same four offices were used for the analysis: Jefferson county judge; Jefferson county coroner; Louisville mayor and Louisville twelfth ward alderman. The first two offices reflect countywide voting; the latter two offices reflect citywide voting. These races were chosen because of distance on the ballot between the county judge and the county coroner positions and between the mayor and twelfth ward aldermanic positions. The years considered were 1933, 1945, 1957, 1961, and for comparison purposes, 1973 and 1977.

There was added interest in determining the voter turnout for these races because in none of the years was there a presidential or a state gubernatorial election. All races on the ballots for those years were local. Appendix IV shows the percentages of registered voters who 
actually voted in the elections ranged from $60 \%$ to $70 \%$. The only exceptions to this pattern was the turnout for the 1977 election. In that year, $40 \%$ to $50 \%$ turnout occurred. Citywide races, again with the exception of 1977, consistently brought out a higher percentage of voters than did the countywide races.

Political scientists generally conclude that voter turnout has declined over recent decades, especially in local races. In Louisville, however, during the period 1933 to 1973 the trend was that of a fairly consistent turnout for local elections. Further research and speculation will ascertain whether the 1977 election was an aberration or the beginning of a local trend of declining turnout.

Additionally, Appendix IV shows that the number of registered voters in that part of Jefferson County outside the Louisville city limits has grown proportionally greater than the number of registered voters within the city limits. In 1973 county voters outnumbered city voters for the first time in the years under study. The relationship between number of registered voters and population growth in Louisville and Jefferson County is discussed below (See Appendix V). This study analyzes the roll-off factor from one particular race to another. In other words, it considered the number of persons voting within the election for candidates in a more highly visible race in relation to the number voting for candidates in a less visible race. Ballot position of a race is of importance in the analysis. Names of those running for the office of county judge are positioned on the voting machine to the left of the names of candidates running for county coroner, with a few races intervening. The same holds true for names of candidates for Louisville's mayor and twelfth ward alderman. 
Appendix VI shows that the roll-off from Democratic county judge to county coroner was in the range of $2 \%$ in the period 1933 to 1961 . The rate for 1973 was $8 \%$ roll-off. In 1977 , there was a $15 \%$ increase rather than a decrease. The Republican county judge-coroner roll-off from 1933 to 1961 was not higher than $2 \%$, with the exception of an increase of $.6 \%$ in 1933 . In 1973 , the roll-off was $6 \%$ and in 1977 it was an astonishing $39 \%$.

Appendix VI also shows that in the races for county judge and county coroner, the Democratic candidates received approximately the same percentage of the total vote from 1933 to 1961 . The same is true for the Republican candidates. Entries for the 1973 election for county judge and county coroner follow the earlier pattern except that the spread between Republican county judge-coroner and the Democratic county judge-coroner is much broader. The 1977 figures show a major deviation from the previous pattern. There is no matching the percentage of the vote received by the Democratic candidates. The same is true for Republicans.

The roll-off from the mayor's race to that for twelfth ward alderman from 1933 to 1961 revealed a pattern of from 1\% to 2\% decline, with the exception of the 1961 Republican match where the roll-off is about $3.5 \%$. The 1973 roll-off in the Democratic pair was $12 \%$ whereas in the Republican pair it was 6\%. In 1977 the Democratic rol1-off remained at $12 \%$ and the Republican roll-off decreased to $22 \%$.

The percentage of the total vote received by brethren Democrats running for mayor and alderman remained consistent in the period from 1933 to 1977. The same is true for Republican compatriots. The previously cited deviation in the 1977 county judge-coroner election did not occur in the city races. 
These figures appear to indicate that during the period from 1933 to 1973 there was little ticket-splitting in cited races. Perhaps the 1973 election showed the beginnings of ticket-splitting in local elections. It is certain, however, that the 1977 county judge's race exhibited a substantial number of voters switching from one party's candidate to another party's candidate in the associated races.

Overall, the trend in local elections was one of straight party voting. And the cited elections prior to 1973 showed a high degree of competitiveness between the two political parties. Perhaps the 1977 experience highlights the nature of elections in an age of media exposure for the candidates, personality-centered politics and a lower degree of party discipline in terms of both the candidates and the voters.

As noted earlier, the population of Louisville peaked in the 1960 census (See Appendix V). Thereafter, Louisville's population declined. That portion of Jefferson County outside the city limits, however, experienced a surge of growth beginning in 1950 and continuing at least through 1970 . During the years 1945 to 1977 , the percentage of the population in Jefferson County which registered to vote remained fairly constant. A partisan breakdown of those registrants show a net average increase in Republican registrants of about $14 \%$. The Democrats experienced a net average increase of $19 \%$. Within the city limits, Democrats had a net gain on the average of $7 \%$. City Republicans, on the other hand, experienced a net average decrease of almost $4 \%$. The growth area for both Democratic and Republican registrants was in the county outside city limits. Leaps in the number of both Republicans and Democrats occurred in the period from 1945 to 1957. 
What might all of the preceding analysis mean to the retrospection of the Democratic organization under Lennie McLaughlin? When McLaughlin was active in leadership of the Democratic party, the turnout of Democrats for general elections was fairly predictable. Democrats did not always vote for Democratic candidates in the general election, but during McI.aughlin's heyday, 1947 to 1961, Democratic candidates usually won the general elections. The 1961 Republican sweep, among other factors, led to McLaughlin's demise as a Democratic leader. But the basis of her support prior to 1961 were the city Democrats. Their growth rate in comparison to that of city Republicans was satisfactory. From 1945 to 1957, the growth rate of registered Republicans who lived in the county outside city limits outweighed the growth of Democrats in that area. From 1957 to 1961 the growth in that area of Democrats doubled that of the Republicans. But there is no question that the increase of Republicans and the fact that growth was occurring in an area over which McLaughlin had less political control had practical consequences for McLaughlin and her organization.

As the population of the total county grew, so did the number of legislative districts upon which basis the Democratic party is structured. Each district has a chair who holds a seat on the Democratic county executive committee. The total number of districts represented on the committee in 1940 was eight. By 1948 there were eleven members representing districts. By 1964, there were seventeen members from districts. As the numbers increased, there were more district chairs with which McLaughlin had to deal. Many of those new members hailed from city fringe areas, outside McLaughlin's traditional bailiwick. Ironically, however, the coalition of Democrats who called 
for McLaughlin's resignation in the early 1960 's were members of the executive committee and others from the eastem and western parts of the City of Louisville.

In summary, the case study of the Louisville and Jefferson County Democratic party shows certain findings. The local party was not a monolithic organization, especially during the 1930's and 1940 's. Primary elections for local offices were competitive. In the 1950's Democratic primaries were less competitive than in the previous twenty years. Even so, factionalism in the local party consistently provided diversity.

For the most part, the local party's factionalism stemmed from splits in the statewide Democratic party. Groups centered on gubernatorial and congressional candidates and incumbents. Local party activists were participants in statewide Democratic networks.

Blacks in Louisville and Jefferson County were not consistent supporters of Democrats in elections from the 1930's to the mid-1960's. As a rule, blacks did not participate in official, Democratic party leadership in Louisville until 1964.

Findings about voter behavior indicate that from 1933 to 1973 voter turnout in general elections for certain local offices consistently ranged from $60 \%$ to $70 \%$ of total registered voters. Analysis of the roll-off factor and the percentage of the vote received by Democrats and Republicans in local races shows consistent straight party voting and insignificant roll-off until 1977.

The study concludes that the focal point of the party's historical narrative, Lennie McLaughlin was unique as a female local party leader. That McLaughlin was a woman had scant impact on her functioning 
effectively as a leader, or a "boss." She managed patronage, legislative and administrative activities and the nomination process. McLaughlin's heyday as party leader coincided with the 1950 's period of local Democratic dominance.

Further research in the areas of local political party structure, functioning and personalities will benefit political scientists and interested persons. In most American cities there have been and are politically interested persons who make it their business to function within and often lead their branches of the two major political parties in America. Many of them were actors in politics during the era of Lennie McLaughlin. There might have been a greater number of them in that period. Whatever the number, however, there are still local partisan personalities who relish and endure the "great game of politics." 
APPENDIX 
APPENDIX I: Number of primary elections won and lost by Lennie McLaughlin's organization, 1933-63.

\begin{tabular}{lcccc}
\hline & $1933-36^{1}$ & $1939-45$ & $1948-63^{1}$ & Tota1 \\
\cline { 2 - 5 } WON & 4 & 1 & 10 & 15 \\
LOST & 2 & 5 & 1 & 8 \\
NO CONTEST & 0 & 3 & 7 & 10 \\
TOTAL & 6 & 9 & 18 & 33 \\
\hline
\end{tabular}

APPENDIX II: Number of citywide primary elections won and lost by Lennie McLaughlin's organization. 2

\begin{tabular}{lcccc}
\hline & $1933-36^{1}$ & $1939-45$ & $1948-63^{1}$ & Total \\
\cline { 2 - 5 } WON & 2 & 0 & 3 & 5 \\
LOST & 0 & 1 & 0 & 1 \\
NO CONTEST & 0 & 2 & 2 & 4 \\
TOTAL & 2 & 3 & 5 & 10 \\
\hline
\end{tabular}

APPENDIX III: Number of countywide primary elections won and lost by Lennie McLaughlin's organization. ${ }^{3}$

\begin{tabular}{lcccc}
\hline & $1933-36^{1}$ & $1939-45$ & $1948-63^{1}$ & Total \\
\cline { 2 - 5 } WON & 2 & 1 & 7 & 10 \\
LOST & 2 & 4 & 1 & 7 \\
NO CONTEST & 0 & 1 & 5 & 6 \\
TOTAL & 4 & 6 & 13 & 23 \\
\hline
\end{tabular}

period.

${ }^{1}$ Lennie McLaughlin was Democratic party secretary during this

2 Includes elections for Louisville mayor and twelfth ward alderman.

${ }^{3}$ Includes elections for U.S, senator, third district congressional representative, Kentucky governor, Kentucky commissioner of agriculture, Jefferson county judge, Jefferson county coroner. 
APPENDIX IV: Voting turnout in general elections and voter registration, 1933-77Louisville/Jefferson County, Kentucky.

\begin{tabular}{|c|c|c|c|c|c|c|}
\hline Year & Office on Ballot & Total Vote & $\begin{array}{l}\text { Number of } \\
\text { Registered } \\
\text { Voters }\end{array}$ & $\begin{array}{l}\text { Number of } \\
\text { Registered } \\
\text { Voters }\end{array}$ & $\begin{array}{l}\text { Total } \\
\text { Registered } \\
\text { Voters }\end{array}$ & $\begin{array}{l}\text { Percentage } \\
\text { Who Voted }\end{array}$ \\
\hline 1957 & $\begin{array}{l}\text { County Judge } \\
\text { County Coroner } \\
\text { Mayor } \\
\text { Alderman }\end{array}$ & $\begin{array}{l}149,955 \\
147,302 \\
105,404 \\
104,295\end{array}$ & 153,235 & 73,584 & 226,819 & $\begin{array}{l}66 \\
65 \\
69 \\
68\end{array}$ \\
\hline 1973 & $\begin{array}{l}\text { County Judge } \\
\text { County Coroner } \\
\text { Mayor } \\
\text { Alderman }\end{array}$ & $\begin{array}{r}202,501 \\
187,628 \\
103,270 \\
92,322\end{array}$ & 149,605 & 157,548 & 307,153 & $\begin{array}{l}66 \\
61 \\
69 \\
62\end{array}$ \\
\hline
\end{tabular}


APPENDIX IV: (continued)

\begin{tabular}{|c|c|c|c|c|c|c|}
\hline Year & Office on Ballot & Total Vote & $\begin{array}{l}\text { Number of } \\
\text { Registered } \\
\text { Voters }\end{array}$ & $\begin{array}{l}\text { Number of } \\
\text { Registered } \\
\text { Voters }^{2}\end{array}$ & $\begin{array}{l}\text { Total } \\
\text { Registered } \\
\text { Voters }\end{array}$ & $\begin{array}{l}\text { Percentage } \\
\text { Who Voted }\end{array}$ \\
\hline 1977 & $\begin{array}{l}\text { County Judge } \\
\text { County Coroner } \\
\text { Mayor } \\
\text { Alderman }\end{array}$ & $\begin{array}{r}191,471 \\
167,332 \\
83,468 \\
69,563\end{array}$ & 174,961 & 203,999 & 378,960 & $\begin{array}{l}50 \\
44 \\
48 \\
40\end{array}$ \\
\hline
\end{tabular}

${ }^{1}$ City of Louisville.

${ }^{2}$ County, outside Louisville,

${ }^{3}$ Estimated figures based on extrapolation 1930-38. Official figures not available.

${ }^{4}$ Estimate based on total number of county voters in 1938, the actual number of Democrats and Republicans in 1936 and the assumption of the same percentage of Independents in 1936 as in 1938. Extrapolated forward assuming the same growth pattern from 1936-38 as 1933-36. 
APPENDIX V: Population of Louisville/Jefferson County, Kentucky (1930-1975).

\begin{tabular}{l|c|c|c}
\hline \multirow{2}{*}{ YEAR } & \multicolumn{3}{|c}{ POPULATION } \\
\cline { 2 - 4 } & City of Louisville & County, outside Louisville & Total \\
\hline 1930 & 307,745 & 47,605 & 355,350 \\
1940 & 319,077 & 66,315 & 385,392 \\
1950 & 369,129 & 115,486 & 484,615 \\
1960 & 390,639 & 320,308 & 610,947 \\
1970 & 361,472 & 33,583 & 695,055 \\
1975 & 326,400 & 403,500 & 729,900 \\
\hline \hline
\end{tabular}


APPENDIX VI: Roll-off rate and percentage of total vote: selected general elections, 1933-77, Louisville/Jefferson County, Kentucky.

\begin{tabular}{|c|c|c|c|c|c|}
\hline Year & $\begin{array}{l}\text { Party/Office } \\
\text { on Ballot }\end{array}$ & $\begin{array}{l}\text { Percent of } \\
\text { Total Vote }\end{array}$ & Total Vote & $\underset{\%}{\operatorname{Ro} 11-o f f}$ & $\underset{\%}{\text { Increase }}$ \\
\hline \multirow[t]{8}{*}{1933} & $\begin{array}{l}\text { DEMOCRATIC: } \\
\text { County Judge }\end{array}$ & 52 & 77,362 & & \\
\hline & County Coroner & 52 & 76,556 & 1 & - \\
\hline & Mayor & 51 & 65,825 & & \\
\hline & Alderman (12th Ward) & 51 & 64,374 & 2 & - \\
\hline & $\begin{array}{l}\text { REPUBLICAN: } \\
\text { County Judge }\end{array}$ & 48 & 70,910 & & \\
\hline & County Coroner & 48 & 71,345 & - & .6 \\
\hline & Mayor & 49 & 62,657 & & \\
\hline & Alderman & 49 & 61,676 & 1 & - \\
\hline \multirow[t]{8}{*}{1945} & $\begin{array}{l}\text { DEMOCRATIC: } \\
\text { County Judge }\end{array}$ & 50 & 55,314 & & \\
\hline & County Coroner & 50 & 55,085 & .4 & - \\
\hline & Mayor & 50 & 46,798 & & \\
\hline & Alderman & 50 & 45,176 & 3 & - \\
\hline & $\begin{array}{l}\text { REPUBL ICAN : } \\
\text { County Judge }\end{array}$ & 50 & 56,008 & & \\
\hline & County Coroner & 50 & 55,507 & .9 & - \\
\hline & Mayor & 50 & 46,577 & & \\
\hline & Alderman & 50 & 45,670 & 2 & - \\
\hline
\end{tabular}


APPENDIX VI: (continued)

\begin{tabular}{|c|c|c|c|c|c|}
\hline Year & $\begin{array}{l}\text { Party/Office } \\
\text { on Ballot }\end{array}$ & $\begin{array}{l}\text { Percent of } \\
\text { Total Vote }\end{array}$ & Total Vote & $\underset{\%}{\operatorname{Roll}}$ & $\underset{\%}{\text { Increase }}$ \\
\hline \multirow[t]{10}{*}{1957} & DEMOCRATIC: & & & & \\
\hline & County Judge & 52 & 57,688 & & \\
\hline & County Coroner & 52 & 56,819 & 1.5 & - \\
\hline & Mayor & 54 & 57,409 & & \\
\hline & Alderman & 54 & 56,641 & 1 & - \\
\hline & REPUBLICAN : & & & & \\
\hline & County Judge & 48 & 48,891 & & \\
\hline & County Coroner & 48 & 47,943 & 2 & - \\
\hline & Mayor & 46 & 47,995 & & \\
\hline & Alderman & 46 & 47,654 & .7 & - \\
\hline
\end{tabular}

1961 DEMOCRATIC:

County Judge

$44 \quad 76,233$

County Coroner

44

75,052

1.5

Mayor

45

50,660

Alderman

46

51,000

.6

REPUBLICAN :

County Judge

5696,233

County Coroner

$56 \quad 94,180$

2

Mayor

55

62,028

Alderman

54

59,878

3.5 
APPENDIX VI: (continued)

\begin{tabular}{|c|c|c|c|c|c|}
\hline Year & $\begin{array}{l}\text { Party/Office } \\
\text { on Ballot }\end{array}$ & $\begin{array}{l}\text { Percent of } \\
\text { Total Vote }\end{array}$ & Total Vote & $\underset{\%}{\operatorname{Ro} 11-\text { off }}$ & $\underset{\%}{\text { Increase }}$ \\
\hline \multirow[t]{8}{*}{1973} & $\begin{array}{l}\text { DEMOCRATIC: } \\
\text { County Judge }\end{array}$ & 63 & 128,365 & & \\
\hline & County Coroner & 63 & 118,054 & 8 & - \\
\hline & Mayor & 69 & 70,496 & & \\
\hline & Alderman & 67 & 62,208 & 12 & - \\
\hline & $\begin{array}{l}\text { REPUBLICAN : } \\
\text { County Judge }\end{array}$ & 37 & 74,136 & & \\
\hline & County Coroner & 37 & 69,574 & 6 & - \\
\hline & Mayor & 31 & 32,227 & & \\
\hline & Alderman & 33 & 30,114 & 6 & - \\
\hline \multirow[t]{8}{*}{1977} & $\begin{array}{l}\text { DEMOCRATIC: } \\
\text { County Judge }\end{array}$ & 47 & 89,818 & & \\
\hline & County Coroner & 63 & 105,298 & - & 15 \\
\hline & Mayor & 65 & 53,038 & & \\
\hline & Alderman & 67 & 46,754 & 12 & - \\
\hline & $\begin{array}{l}\text { REPUBLICAN : } \\
\text { County Judge }\end{array}$ & 53 & 101,653 & & \\
\hline & County Coroner & 37 & 62,034 & 39 & - \\
\hline & Mayor & 35 & 29,092 & & \\
\hline & Alderman & 33 & 22,809 & 22 & - \\
\hline
\end{tabular}


APPENDIX VII: Number of registered voters, 1930-77 - Louisville/Jefferson County, Kentucky.

\begin{tabular}{|c|c|c|c|c|c|c|}
\hline Year & $\begin{array}{l}\text { City } \\
\text { Democrats }\end{array}$ & $\begin{array}{l}\text { County } \\
\text { Democrats }\end{array}$ & Total & $\begin{array}{l}\text { City } \\
\text { Republicans }\end{array}$ & $\begin{array}{l}\text { County } \\
\text { Republicans }\end{array}$ & Total \\
\hline 1930 & 37,160 & -1 & -2 & 74,698 & -1 & -2 \\
\hline 1936 & -2 & 13,183 & -2 & -2 & 6,515 & -2 \\
\hline 1938 & 84,305 & 17,064 & 101,369 & 52,771 & 8,250 & 61,021 \\
\hline 1945 & 80,164 & 19,650 & 99,814 & 48,140 & 9,350 & 57,490 \\
\hline 1957 & 91,322 & 40,265 & 131,587 & 46,594 & 25,195 & 71,789 \\
\hline 1961 & 100,856 & 54,401 & 155,257 & 46,859 & 29,418 & 76,277 \\
\hline 1973 & 95,068 & 87,185 & 182,253 & 43,717 & 58,448 & 102,165 \\
\hline 1977 & 116,758 & 118,517 & 235,275 & 44,356 & 67,520 & 111,876 \\
\hline
\end{tabular}

${ }^{1}$ In 1930, the city maintained a registration system. Prior to 1936 , the remainder of Jefferson County did not have a permanent registration system.

${ }^{2}$ No official figures available. 
REFERENCES

Baker, John H. Urban Politics in America. New York: Scribners, 1971.

Barber, James David. Political Leadership in American Government. Boston: Little, Brown \& Co., 1964.

Berry, George. Interviews, Tape Recordings 非1, $62 \mathrm{C}$ and 63 . Louisville, Kentucky: University of Louisville Archives, 1974.

Bowman, Lewis and Boynton, G. R. "Recruitment Patterns Among Local Party Officials: a model and some preliminary findings in selected locales." American Political Science Review, 60, (Summer, 1966), 667-676.

Bruner, Jerome S. and Korchin, Sheldon J. "The Boss and the Vote: Case Study in City Politics." Public Opinion Quarterly 10 (1946), 1-23.

Callow, Alexander B., Jr., ed. The City Boss in America: An Interpretive Reader. New York: Oxford University Press, 1976.

"City Bosses and Political Machines." Annals of the American Academy of Political and Social Science, 353 (May, 1964).

Clarke, Harold D. and Kornberg, Allan. "Moving Up the Political Escalator: Women Party Officials in the United States and Canada." The Journal of Politics. 41 (1979), 442-47.

Collins, Ernest. "The Political Behavior of the Negroes in Cincinnati, Ohio and Louisville, Kentucky." Ph.D. Dissertation, University of Kentucky, 1950.

Conway, M. Margaret and Feigert, Frank B. "Motivation Incentive Systems and the Political Party Organization." American Political Science Review. 62 (December, 1968), 1159-1173.

Cook, Fred J. American Political Bosses and Machines. New York: Franklin Watts, Inc., 1973.

Costantini, Edmond and Craik, Kenneth H. "Women as Politicians: The Social Background, Personality, and Political Careers of Female Party Leaders." Journal of Social Issues, 28 (2, 1972), 217-235.

Costikyan, Edward N. Behind Closed Doors. New York: Harcourt, Brace \& World, Inc., 1966. 
Cotter, Cornelius and Bibby, John F. "Institutional Development of Parties and the Thesis of Party Decline." Political Science Quarterly. (Spring, 1980), 1-29.

Dorsett, Lyle, W. Franklin D. Roosevelt and the City Bosses. Port Washington, New York: Kennikat Press, 1977.

Erskine, Hazel. "The Polls: Women's Role." Public Opinion Quarterly. 35 (Summer, 1971), 275-290.

Githens, Marianne and Prestage, Jewel L., eds. A Portrait of Marginality: The Political Behavior of the American Woman. New York: D. McKay Co., 1977.

Gruberg, Martin. Women in American Politics. Oshkosh, Wisc.: Academic Press, 1968.

Hershkowitz, Leo. Tweed's New York. Garden City, New York: Anchor Press/Doubleday, 1977.

Hirschfield, Robert S., Swanson, Bert E.; and Blank, Blanche D. "A Profile of Political Activists in Manhattan." Western Political Quarterly 15 (September, 1962), 489-506.

Holli, Melvin. "Social and Structural Reform." The City Boss in America. Edited by Alexander B. Callow, Jr. New York: Oxford University Press, 1976.

Jacquette, Jane S., ed. Women in Politics. New York: John Wiley and Sons, 1974 .

Jennings, M. Kent and Farah, Barbara G. "Social Roles and Political Resources: An Over-Time Study of Men and Women in Party Elites." Paper presented at the 36th annual meeting of the Midwest Political Science Association, Chicago, ILlinois, April, 1978.

and Thomas, Norman. "Men and Women in Party Elites: Social Roles and Political Resources." Midwest Journal of Political Science. 7 (November, 1968), 469-492.

Johnson, Marilyn. "Women and Elective Office." Social Science and Public Policy. May/June, 1980, pp. 63-69.

Johnson, Walter. 1600 Pennsylvania Ave: Presidents and the People Since 1929. Boston: Little, Brown \& Co., 1963.

Ken: The Magazine of Kentucky Affairs. November, 1956, pp. 1-23.

Kent, Frank R. The Great Game of Politics. New York: Doubleday, Doran \& Co., Inc., 1923. 
Kirkpatrick, Jeane J. Political Women. New York: Basic Books, Inc., 1974.

- The New Presidential Elite: Men and Women in National Politics. New York: Russell Sage Foundation, 1976.

Lee, Marcia M. "Toward Understanding Why Few Women Hold Public office: Factors Affecting the Participation of Women in Local Politics." A Portrait of Marginality. Edited by Marianne Githens and Jewel L. Prestage. New York: D. McKay Co., 1977.

Lowi, Theodore J. "Machine Politics - 01d and New." The City Boss in America. Edited by Alexander B. Callow, Jr. New York: Oxford University Press, 1976.

Lupsha, Peter. "The Politics of Urban Change." The City Boss in America. Edited by Alexander B. Callow, Jr. New York: Oxford University Press, 1976.

Mandelbaum, Seymour J. Boss Tweed's New York. New York: John Wiley and Sons, Inc., 1965.

McKitrick, Eric L. "The Study of Corruption." Urban Bosses, Machines and Progressive Reformers. Edited by Bruce M. Stave. Lexington, Mass.: D. C. Heath \& Co., 1972.

Merton, Robert K. "The Latent Functions of the Machine." Urban Bosses, Machines and Progressive Reformers. Edited by Bruce M. Stave. Lexington, Mass.: D. C. Heath \& Co., 1972.

Mezey, Susan Gluck. "Women and Representation: The Case of Hawaii." The Journal of Politics. 40 (1978), 369-385.

0'Connor, Edwin. The Last Hurrah. Boston: Little, Brown \& Co., 1956.

Orth, Samuel P. The Boss and The Machine. New Haven: Yale University Press, 1919 .

Porter, Mary Cornelia and Matasar, Ann B. "The Role and Status of Women in the Daley Organization." Women in Politics. Edited by Jane S. Jacquette. New York: John Wiley and Sons, 1974.

Rogow, Arnold A. and Lasswell, Harold D. "The Boss and His Past: Game and Gain Politicians." Political Leadership in American Government. Edited by James David Barber. Boston: Little, Brown \& Co. , 1964.

Rosenberg, Marie Barovic and Bergstrom, Len V., eds. Women and Society: A Critical Review of the Literature with a Selected Annotated Bibliography. Beverly Hills, Calif.: Sage Publications, 1975.

Russe11, Francis. The President Makers: From Mark Hanna to Joseph P. Kennedy. Boston: Little, Brown \& Co., 1976. 
Rutgers University, New Brunswick, N.J., Center for the American Women and Politics, Eagleton Institute of Politics. Women in Public Office: a Biographical Directory and Statistical Analysis. New York: R. R. Bowker Co., 1976.

Salisbury, Robert H. "Urban Politics: The New Convergence of Power." The Journal of Politics. 26 (1964), 775-797.

Stanwick, Kathy. The Political Participation of Women in the U.S.: A Selected Bibliography, 1960-1976. Center for the American Woman and Politics, Eagleton Institute of Politics, Rutgers University, Metuchen, N.J.: Scarecrow Press, 1977.

Stave, Bruce M. ed. Urban Bosses, Machines and Progressive Reformers. Lexington, Mass.: D. C. Heath \& Co., 1972.

Steinberg, Alfred. The Bosses. New York: Macmillan Co., 1972.

Steinfe1d, Samue1. Interviews, Tape Recordings \#75 A \& B. Louisville, Kentucky: University of Louisville Archives, 1974.

Tolchin, Susan and Tolchin, Martin. Clout: Woman Power and Politics. New York: Capricorn Books, 1976.

Tugwe11, Rexford G. The Brains Trust. New York: Viking, 1968.

Welch, Susan. "Women as Political Animals?: A Test of Some Explanations for Male-Female Political Participation Differences." American Journal of Political Science. XXI (November, 1977), 711-729

Werner, Emmy E. and Bachtold, Louise M. "Personality Characteristics of Women in American Politics." Women in Politics. Edited by Jane S. Jacquette. New York: John Wiley and Sons, 1974.

"What Women Do In Politics: Interviews with the Two Women Leaders of the Republican and Democratic Parties." U.S. News and World Report, December 12, 1958, pp. 72-79.

Willis, G. L. Kentucky Democracy: A History of Party and its Representative Members - Past and Present. Louisville, Kentucky: By the Author, 1933.

Wilson, James Q. The Amateur Democrat: Club Politics in Three Cities. Chicago: University of Chicago Press, 1962.

Yater, George H. Two Hundred Years at the Falls of the Ohio: A History of Louisvilie and Jefferson County. Louisville, Kentucky: The Heritage Corporation, 1979.

Yates, Sarah Roberson and Gray, Karen Roessler. "When Politics was a Girlie Show." Louisville Today. Juen, 1981, pp. 18-21; 52-55.

Zink, Harold. City Bosses in the United States. Durham, N.C.: Duke University Press, 1930 . 
News Articles

NOTE: The following sources are listed in chronological order to facilitate future research.

$\underline{1930-1939}$

Hart, Joe. "Bosses Are Born - Not Elected." Courier-Journa1, December $11,1938$.

"Welsh Heads Democratic Committee." Courier-Journa1, April 4, 1939.

"Burke Replaces Party Worker." Louisville Times, April 20, 1939.

Hart, Joe. "Secretary Makes Fight To The Last." Courier-Journal, April 20, 1939.

Hart, Joe. "Mrs. McLaughlin Pays Up To 1942." Courier-Journal, Apri1 21, 1939.

"Party Lease Tales Spiked." Louisville Times, April 24, 1939.

Hart, Joe. "McLaughlin Resigns Post As Secretary - Quits As Ouster By Democrats Matter of Hours." Courier-Journal, April 25, 1939.

"'Substantial Sum' Left by Mrs, McLaughlin." Louisville Times, April 26, 1939.

"Theisen Handed Democrat Post." Louisville Times, May 11, 1939.

$\underline{1940-1949}$

Hart, Joe. "Mrs. McLaughlin May Get Job Back." Courier-Journal; January 1, 1940.

Hart, Joe. "Ripper Bill Believed Aimed At Mrs. Lennie McLaughlin." Courier-Journal, February 22, 1940.

"Mrs. McLaughlin, On Ouster Anniversary, Says She Wants To Get Out, But People Won't Let Her While Democrats Squabble." Louisville Times, April 25, 1940.

"Lennie Boomed For Court Job." Louisville Times, June 24, 1940.

"Job Looms For Ex-Officer of Democrats." Courier-Journal, June 25, 1940.

"Lennie Gets \$3,600 Post." Louisville Times, July 9, 1940.

Porter, Marion. "Miss Lennie Enjoys Breathing Spell After Years in Political Game." Courier-Journal, July 27, 1940.

"City-County Democratic Shakeup Due." Courier-Journal, December 3, 1940. 
Riggs, Robert. "Neville Miller Is Reported Sought As Head of Democratic Party Here." Courier-Journal, April 4, 1944.

"Fiscal Court Deadlocks on Clerkship." Courier-Journal, June 23, 1944.

"Fiscal Court Storm Rages." Courier-Journal, June 26, 1944.

"Beauchamp Snorts 'Blatherskite' At White In Fiscal Court Deadlock." Courier-Journal, June 27, 1944.

Conne11, Thornton. "Win Or Lose, Beauchamp Owes Credit For Remarkable Race to 'Miss Lennie'." Courier-Journal, August 7, 1945.

Hart, Joe. "Party Reorganization Is Scheduled; Return of Mrs. McLaughlin Talked." Courier-Journal, January 8, 1947.

"Dugan Resigns Before Vote; Move Expected to Improve Feelings Between Party Groups." Courier-Journal, January 9, 1947.

"Scholtz Opposed by 'Miss Lennie'." Courier-Journal, January 10, 1947.

"Taylor O.K. of 'Miss Lennie' Rated As Last-Resort Move." CourierJournal, January 15, 1947.

Lord, Frederic C. "County Dem Chiefs Get 'Say' Over Bills Sent to Assembly." Louisville Times, January 14, 1948.

"Tay1or to Meet with Legislators." Courier-Journal, January 15, 1948.

"Democrats Loath to Present Louisville's Bills For Fear of Voter Blame When Taxes Rise." Louisville Times, January 15, 1948.

"Broker Given Edge For Job As Mayor." Courier-Journal, February 26, 1948.

Conne11, Thornton. "Farnsley May Be Known As 'The Peacemaker'." Courier-Journal, March 4, 1948.

Lord, Frederic C. "'Miss Lennie' Ouster Talked As Race Wire Ban Defeated." Louisville Times, March 19, 1948.

"It Was the Voters Who Elected Farnsley." Courier-Journal, Editorial, December 3, 1948.

"More Political Instruction In Store For Us." Louisville Times, Editorial, December 8, 1948.

Conne11, Thornton. "Mayor Claims Victory; May Appeal." CourierJournal, December 12, 1948.

"Out-of-Date Voting Lists Are An Invitation to Thievery." Louisville Times, Editorial, July 26, 1949. 
$\underline{1950-1959}$

Leopold, Helen. "'Miss Lennie' - The Woman Who Runs Things In CityCounty Politics." Louisville Times, March 19, 1952.

Lord, Frederic C. "Little-Attended Democratic Meetings Leave Party Control In Same Hands." Louisville Times, December 9, 1952.

"Mrs. Lennie W. McLaughlin Named To National Advisory Committee." Courier-Journal, September 14, 1955.

Reeves, Ben. "It's 'Madame Labor' vs. 'Miss Lennie' - And No Holds Barred." Courier-Journa1, March 18, 1956.

Freeman, Don. "'What A Farce!' Those Leaving Shout; Mrs. McLaughlin Says 'We Won Fairly'." Courier-Journal, July 4, 1956.

"Happy On Louisville, Then and Now." Louisville Times, Editorial, July $9,1956$.

"Real Intraparty Battle Expected Here on Dec. 8." Courier-Journal, November 29, 1956.

"Regulars Remain in Control of County Democratic Organization." Courier-Journal, December 9, 1956.

Harwood, Richard. "Politics WERE the Damnedest." Louisville Times, May 12, 1959.

. "Over 5,000 Party Organization Workers Helped Combs Pile Up 29,000 Majority Here." Louisville Times, June 2, 1959.

$\underline{1960-1969}$

Connell, Thornton. "Queenan Plans Race For Mayor." Courier-Journal, June 16, 1960.

- "Democrats Here Rename Organization Officials." CourierJourna1, December 11, 1960.

Harwood, Richard. "Democrats Showing No Concern Over Talk of Negro Revolt in City Election." Louisville Times, February 16, 1961.

"River-Front Rezoning Issue Raised by Cowgar." Courier-Journal, September 9, 1961.

Conne11, Thornton. "Burke Is Backing Wyatt In Race With Lowman." Courier-Journal, February 7, 1962.

"Touching A11 Bases." Louisville Times, October 19, 1962.

"Democrats Dismayed." Louisville Times, November 7, 1962. 
Conne11, Thornton. "'Organization' Has Been Down But Never Out." Courier-Journal, November 18, 1962.

"Jefferson Race Gets Spotlight." Louisville Times, May 25, 1964.

Swift, Ivan. "Blume Bloc Driving To Oust Miss Lennie." Louisville Times, June 11, 1964.

Deitz, Robert. "Blume-Led Rebels Rap Party Chiefs." Courier-Journal, June 12, 1964.

"Labor Helps Widen Split of Democrats." Courier-Journal, June 17, 1964.

Deitz, Robert. "Bossmeyer Shuns Reelection Race." Courier-Journal, June 7, 1964.

Swift, Ivan. "Clarke Wins Democratic Campaign Rule." Louisville Times, August 14, 1964.

Deitz, Robert. "Breathitt Is Guiding Party Here." Courier-Journal, August 14, 1964.

- "Victors Mull Party Revamp." Courier-Journal, November 5, 1964.

Swift, Ivan. "Group Meets To Take Democratic Party Control From Leaders." Louisville Times, November 5, 1964.

- "Rebel Democrats Open Battle For Control." Louisville Times, November 6, 1964.

Deitz, Robert. "Fight For Democratic Party Rule Simmering Here." Courier-Journal, November 22, 1964.

Ayer, Jack. "Battle For The Brennan Building." Louisville Times, November 24, 1964.

. "Democratic Donnybrook." Louisville Times, December 3, 1964.

Deitz, Robert. "Precinct Democrats Elect." Courier-Journal, December 6, 1964.

- "Democrats In Jefferson Reorganize." Courier-Journal, December 13, 1964.

- "Miss Lennie' Is Resigning." Courier-Journal, December 9, 1965.

Greider, William. "Legendary Lady...Miss Lennie Ends Long Career In Politics." Louisville Times, December 9, 1965.

"The Democrats' Doyenne Retires." Louisville Times, Editorial, December 10, 1965.

"2 Replacing 'Miss Lennie'." Courier-Journal, January 31, 1966. 
"2 Democrats to Share Organizational Duties." Louisville Times, January 31, 1966.

"Democratic Party Honors 'Miss Lennie'." Courier-Journal, April 7, 1966.

"Democrats Honor 'Miss Lennie'." Courier-Journal, Aptil 16, 1966.

"Honors Paid 'Miss Lennie'." Louisville Times, April 16, 1966.

"Democrats Honor Miss Lennie." Courier-Journal, Apri1 22, 1966.

$\underline{1970-1979}$

Bulleit, Paul. "Miss Lennie Recalls Power and Presidents." Courier-Journal, January 23, 1976. 
Carolyn Luckett Denning was born July 24, 1943 in Louisville, Kentucky, the daughter of Martin Joseph and Ruth Cullen Luckett. She is the wife of Thomas Urban Denning. She was educated in elementary and secondary private schools in Louisville. She graduated from Loretto High School in 1961 and entered Loretto Junior College in Nerinx, Kentucky in the fall 1961. She enrolled at Webster College, St. Louis, Missouri and graduated with a B.A. degree in History May 1966.

In 1973 , she began her graduate studies at the University of Louisville in the Department of Political Science. She was awarded a graduate teaching assistantship in that department in the fall of 1975 . Additionally, she taught at the Jefferson Community College from 1977 to 1978. She received appointment as Clerk to the Louisville Board of Aldermen serving from 1975 through 1981. She received a degree of Master of Arts in Political Science in August 1981. 